\title{
THESIS
}

\section{ASSESSMENT OF MUNICIPAL SOLID WASTE SETTLEMENT MODELS BASED ON FIELD-SCALE DATA ANALYSIS}

\author{
Submitted by \\ Seungbok Kwak \\ Department of Civil \& Environmental Engineering
}

In partial fulfillment of the requirements

For the Degree of Master of Science

Colorado State University

Fort Collins, Colorado

Summer 2014

Masters Committee:

Advisor: Christopher A. Bareither

Charles D. Shackelford

Ann M. Hess 
Copyright by Seungbok Kwak, 2014

All Rights Reserved 


\section{ABSTRACT}

\section{ASSESSMENT OF MUNICIPAL SOLID WASTE SETTLEMENT MODELS BASED ON FIELD- SCALE DATA ANALYSIS}

An evaluation of municipal solid waste (MSW) settlement model performance and applicability was conducted based on analysis of two field-scale datasets: (1) Yolo and (2) Deer Track Bioreactor Experiment (DTBE). Yolo data were used to assess a multi-layer immediate settlement analysis and model applicability to represent compression behavior in conventional and bioreactor landfills. The DTBE included four waste layers constituting a composite waste thickness. Settlement data for each waste layer were simulated to assess variation in model parameters, and a composite waste settlement prediction was completed via applying average DTBE model parameters to each waste layer and summing settlement to represent measured settlement at the top of the waste column.

The multi-layer immediate settlement analysis developed for Yolo provides a framework to estimate the initial waste thickness and waste thickness at end-of-immediate compression. An empirical estimate of the immediate compression ratio $\left(C_{c}^{\prime}=0.23\right)$ combined with precompression stress $\left(10\right.$ to $15 \mathrm{kPa}$ ) and recompression ratio $=1 / 10 \cdot C_{c}{ }^{\prime}$ yielded the target immediate settlement for the Yolo test cells. A precompression stress and recompression ratio may need to be included when using empirical estimates of $C_{c}{ }^{\prime}$ to predict immediate settlement under small vertical stress (e.g., less than $15 \mathrm{kPa})$.

Simulation of the Yolo test cells with all settlement models via least squares optimization yielded high coefficient of determinations $\left(R^{2}>0.83\right)$. However, empirical models (power creep, logarithmic, and hyperbolic) are not recommended for use in MSW settlement modeling due to non-representative long-term MSW behavior, limited physical significance of model parameters, and the requirement of measured data to determine model parameters. 
Settlement models that combine mechanical creep and biocompression into a single mathematical function (i.e., Gibson and Lo and Chen-2010) are formulated to constrain all timedependent settlement to a single process with finite magnitude, which limits model applicability. Overall, all other models used in this analysis, which either have the capability to simulate complete MSW compression behavior (Sowers, Marques, Babu, Chen-2012) or where an immediate compression component can be added to the model (Gourc and Machado), were shown to provide accurate simulations and predictions of field-scale datasets.

The Gourc model included the lowest number of total and optimized model parameters and yielded high statistical performance for the DTBE prediction $\left(R^{2}=0.99\right)$. The Gourc model was also found to be the most applicable and straightforward to implement and is recommended for use in practice. All other models that included unique functions for immediate compression, mechanical creep, and biocompression (Machado, Sowers, Marques, Babu, and Chen-2012) are capable of yielding satisfactory MSW simulations and predictions; however, additional model and/or model constraints are necessary for implementing these models. 


\section{ACKNOWLEDGEMENTS}

I would never have been able to finish my thesis without the guidance of my committee members, help from friends, and support from my family and wife. I would like to express my deepest gratitude to my advisor, Dr. Christopher Bareither, for his excellent guidance and patience as well as providing me with an excellent atmosphere for doing research as well as financial support. I would also like to thank Dr. Charles Shackelford and Dr. Ann Hess for serving on my graduate committee.

I would like to thank Dr. Tae-Hyung Lee, Jong-Ho Shin, Dong-Ho Ha, and Kee-Won Seong who encouraged me to study abroad after graduation in Konkuk University, Korea. They taught me a lot of course works in English and spent time preparing references when I decided to apply to universities in the U.S.

I would like to thank Dr. Geoff Chao who taught "Foundation Engineering," which was challenging to me especially for designing various types of foundations as a final project. Dr. Chao also provided helpful advice for my future after graduation.

I would also like to thank my parents in Korea, and younger brother in New Zealand. They

were always supporting me and encouraging me with their best wishes. They shared every emotion even though being far away.

Finally, I would like to thank my wife, Hye Won Lee. She was always with me cheering me up and stood by me through the good times and bad. 


\section{TABLE OF CONTENTS}

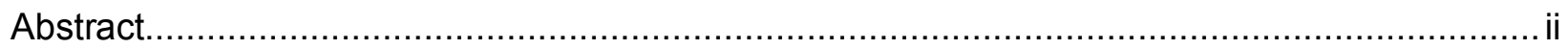

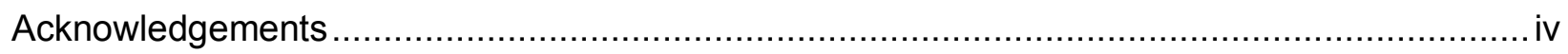

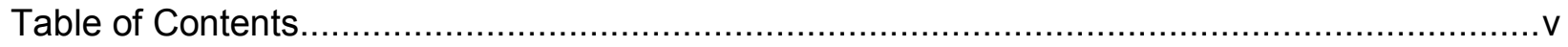

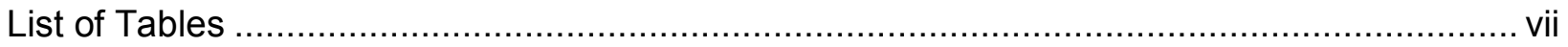

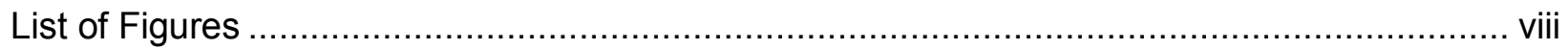

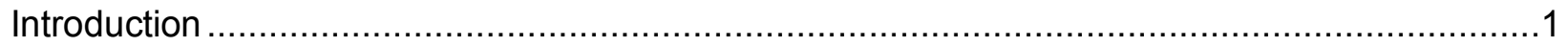

Mathematical Formulations of MSW Compression Processes ..........................................

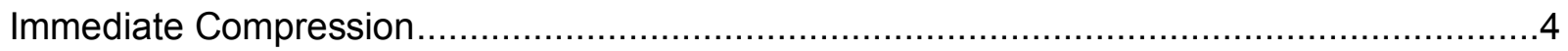

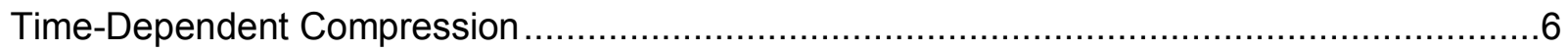

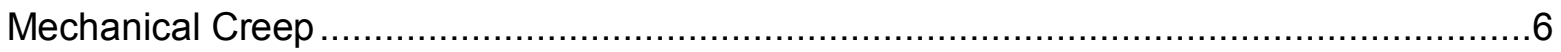

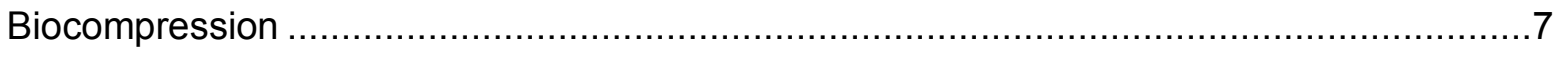

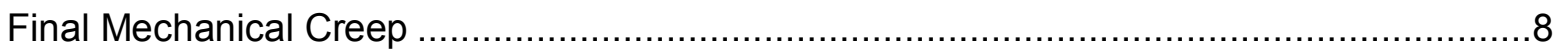

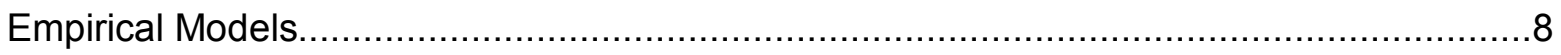

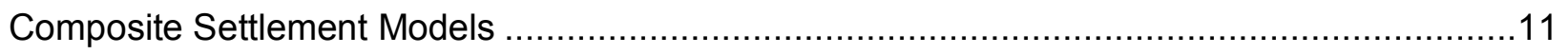

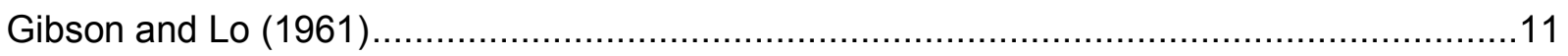

Sowers (1973); Bjarngard and Edgers (1990); Hossain and Gabr (2005) ........................12

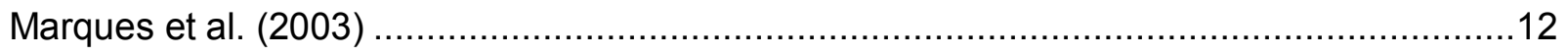

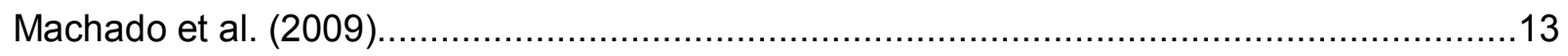

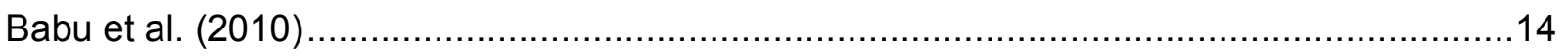

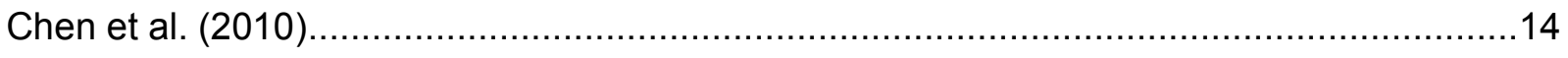

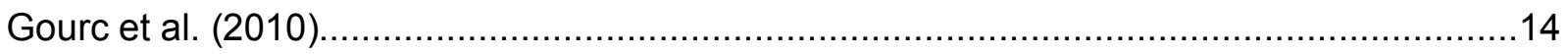

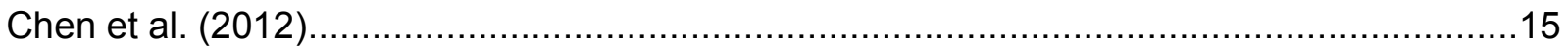




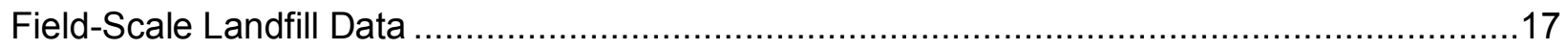

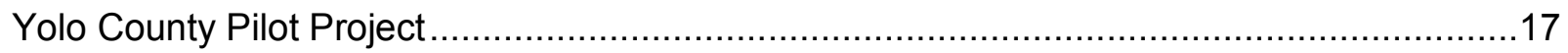

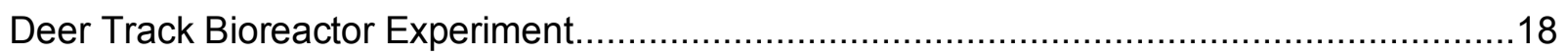

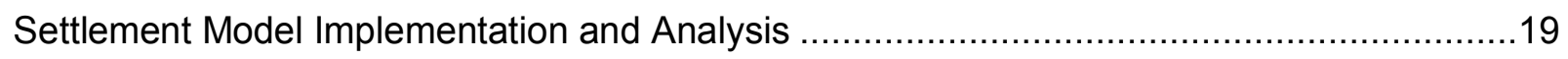

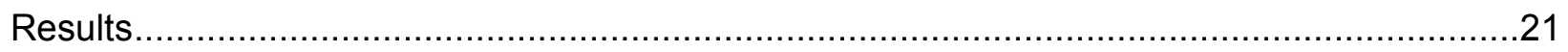

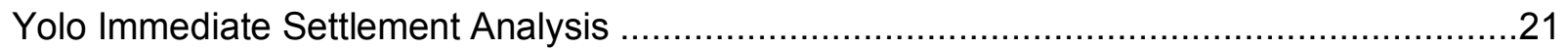

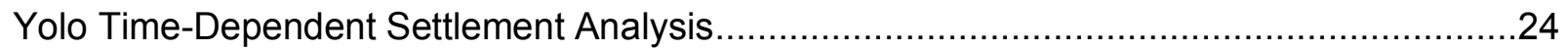

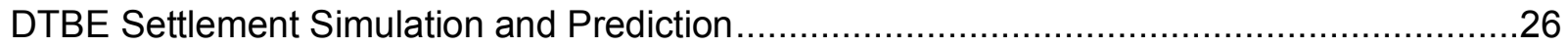

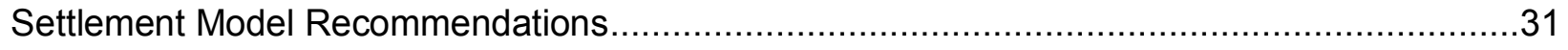

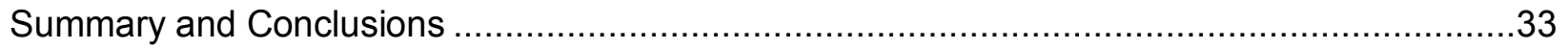

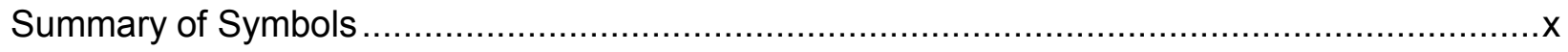

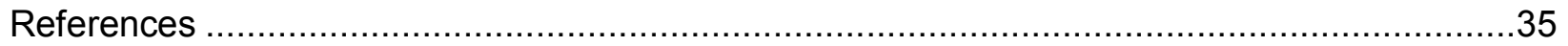

Appendix A: Supplemental Discussion of Municipal Solid Waste Settlement Models ...............58

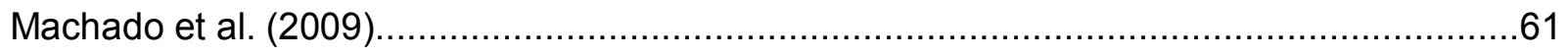

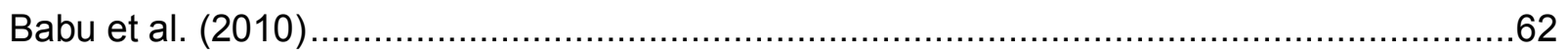

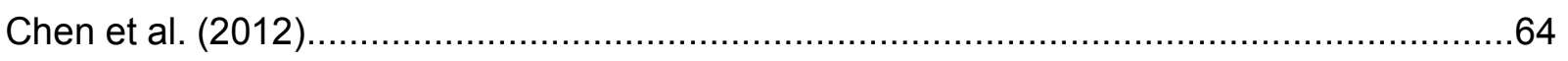

Appendix B: Filling Sequence and Waste Layer Calculations for the Deer Track Bioreactor

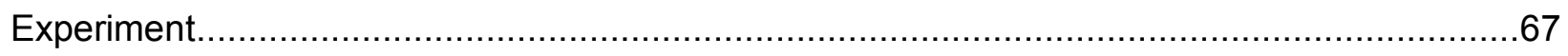

Appendix C: Supplemental waste settlement Plots for waste layers 2, 3, and 4 in the Deer Track

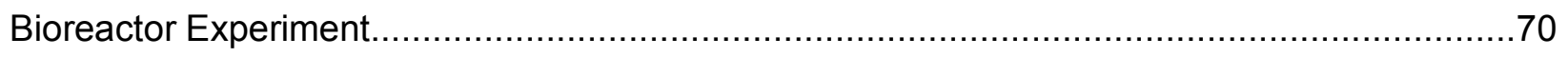




\section{LIST OF TABLES}

Table 1. Summary of ranges for settlement model parameters.

Table 2. Average waste properties of the Control and Enhanced cells, Yolo Co. Pilot Project (Mehta et al. 2002; Yazdani et al. 2006)

Table 3. Waste properties of Deer Track Bioreactor Experiment for waste layers after initial filling (prior to subsequent waste placement) and waste layers at the end-of-filling (prior to placement of final gravel layer) (Bareither et al. 2012b).

Table 4. Summary of waste settlement models used for simulations

Table 5. Summary of the multi-layer immediate compression analyses conducted for the Control and Enhanced cells at Yolo.

Table 6. Summary of model parameters and coefficients of determination for the full composite waste settlement models based on Yolo data.

Table 7. Summary of model parameters and coefficients of determination for the timedependent waste settlement models based on Yolo data.

Table 8. Summary of model parameters and coefficients of determination for the full composite waste settlement models based on DTBE data....

Table 9. Summary of model parameters and coefficients of determination for the timedependent waste settlement models based on DTBE data. 


\section{LIST OF FIGURES}

Fig. 1. Conceptual models of municipal solid waste settlement with (i) inhibited and (ii) complete waste decomposition. Temporal definitions: $t_{M}=$ elapsed time for endof-immediate compression, $t_{B}=$ elapsed time for onset of biocompression, and $t_{F}=$ elapsed time for completion of waste biodegradation and transition to final mechanical creep.

Fig. 2. Temporal trends of waste thickness and settlement for the Yolo Enhanced and Control cells.

Fig. 3. (a) Schematic of the Deer Track Bioreactor Experiment and temporal relationships of (b) total waste settlement measured for each settlement plate and (c) settlement of individual waste layers.

Fig. 4. Total waste thicknesses and individual waste layer thickness for the Enhanced and Control cells at Yolo. Dashed lines indicate individual waste layer thicknesses; these thicknesses for $\mathrm{H}_{235}, \mathrm{H}_{500}$, and $\mathrm{H}_{3980}$ are averages from the model simulations. The waste thickness corresponding to $\mathrm{H}_{0}$ and $\mathrm{H}_{\mathrm{EO}}$ are based on assumptions outlined in the multi-layer settlement analysis. Waste thicknesses corresponding to $\mathrm{H}_{235}$ and $\mathrm{H}_{3980}$ are based on final cover elevation surveys conducted at Yolo.

Fig. 5. Measured settlement and settlement model fits for the Yolo Control and Enhanced cells.

Fig. 6. Coefficient of determination versus total number of model parameters for (a) Control cell and (b) Enhanced cell and versus number of optimized model parameters for (c) Control cell and (d) Enhanced cell. Settlement model references: $a=$ Gibson and Lo; $b=$ Sowers; $c=$ Logarithm; $d=$ Power Creep; $e$ = Hyperbolic; $\mathrm{f}=$ Park and Lee; $\mathrm{g}=$ Marques; $\mathrm{h}=$ Machado; $\mathrm{i}=\mathrm{Babu} ; \mathrm{j}=$ Chen2010; k = Gourc; and I = Chen-2012.

Fig. 7. Cumulative settlement versus time for Waste Layer 1 (WL1) of the DTBE data as well as fitted and predicted settlement. Prediction was generated via applying average, optimizted model parameters from the four waste layers in the DTBE to WL1 conditions.

Fig. 8. Relationships between (a) coefficient of volume compressibility and immediate compression strain for Gibson and Lo model and (b) time-dependent compression parameter versus vertical stress increase for the Gibson and Lo, Marques, and Babu models. Model parameters are from the four waste layer settlement simulations conducted for the Deer Track Bioreactor Experiment. 
Fig. 9. Box plot of the normalized difference between settlement model parameters for a given waste layer (WL) in the Deer Track Bioreactor Experiment (DTBE) and the arithmetic average of model parameters for all four WLs in the DTBE. The box represents the middle $50 \%$ of the data; the central line in the box represents the median; the outer boundaries represent the interquartile range (i.e., $25^{\text {th }}$ and $75^{\text {th }}$ percentile); and the upper and lower whiskers extending from the box constitute $5^{\text {th }}$ and $95^{\text {th }}$ percentile of the data.

Fig. 10. Measured settlement at the top of the DTBE (Plate 4), model fit based on use of layer-specific optimized model parameters, and prediction based on use of average, optimized model parameters for each waste layer.

Fig. 11. Schematic of filling sequence in the DTBE and corresponding equations used to compute waste characteristics for the initial-filling and end-of-filling scenarios.

Fig. 12. Measured, simulated, and predicted settlement for Waste Layer 2 in the DTBE. Predicted settlement is based on the arithmetic average of optimized model parameters from the four simulated waste layers.

Fig. 13. Measured, simulated, and predicted settlement for Waste Layer 3 in the DTBE. Predicted settlement is based on the arithmetic average of optimized model parameters from the four simulated waste layers.

Fig. 14. Measured, simulated, and predicted settlement for Waste Layer 4 in the DTBE. Predicted settlement is based on the arithmetic average of optimized model parameters from the four simulated waste layers. 


\section{LIST OF SYMBOLS}

\begin{tabular}{|c|c|c|c|}
\hline$A$ & air phase compression coefficient & $B$ & interactive constant related to biodegradation \\
\hline a & $\begin{array}{l}\text { compressibility parameter due to } \\
\text { immediate compression }\end{array}$ & $b$ & $\begin{array}{c}\text { compressibility parameter due to creep and } \\
\text { biocompression }\end{array}$ \\
\hline$C_{c}^{\prime}$ & immediate compression ratio & $C_{m}$ & organic matter methane yield \\
\hline$C_{\alpha M^{\prime}}$ & mechanical creep ratio & $C_{\alpha B^{\prime}}$ & biocompression ratio \\
\hline$C_{\alpha M F^{\prime}}$ & $\begin{array}{l}\text { final mechanical creep ratio after } \\
\text { completion of biocompression }\end{array}$ & $c_{t}$ & $\begin{array}{l}\text { constant rate due to coupled mechanical } \\
\text { creep and biocompression }\end{array}$ \\
\hline$k$ & $\begin{array}{l}\text { constant rate of strain due to } \\
\text { decomposition }\end{array}$ & $L_{o}$ & methane generation potential \\
\hline$M$ & frictional constant & $M_{\text {so }}$ & $\begin{array}{c}\text { organic fraction of the biodegradable solid in } \\
\text { MSW }\end{array}$ \\
\hline$M_{s o}^{*}$ & initial solid mass & $t_{M}$ & $\begin{array}{l}\text { transition from immediate compression to } \\
\text { mechanical creep }\end{array}$ \\
\hline$t_{B}$ & $\begin{array}{l}\text { transition from mechanical creep to } \\
\text { biocompression }\end{array}$ & $t_{F}$ & $\begin{array}{l}\text { transition from biocompression to final } \\
\text { mechanical creep }\end{array}$ \\
\hline$u_{a}$ & excess pore gas pressure & $u_{\circ}$ & initial pore gas pressure \\
\hline$\alpha^{*}$ & $\begin{array}{l}\text { rate of increase in parameter } \alpha \text { as } \\
\text { biodegradation occurs }\end{array}$ & $\sigma_{\mathrm{vo}}$ & initial vertical stress at mid-depth of waste \\
\hline$\Delta \sigma_{\mathrm{v}}$ & $\begin{array}{c}\text { increase in vertical stress at mid-depth } \\
\text { of waste }\end{array}$ & $\varepsilon_{\mathrm{BIO}}$ & total amount of strain due to biodegradation \\
\hline$\varepsilon_{\mathrm{MB}}$ & $\begin{array}{l}\text { ultimate strain due to mechanical } \\
\text { creep and biocompression }\end{array}$ & $\eta$ & stress ratio $\left(=q / p^{\prime}\right)$ \\
\hline$\kappa$ & recompression or swelling index & $\lambda$ & compression index \\
\hline$\lambda / \mathrm{b}$ & $\begin{array}{l}\text { rate of compression due to creep and } \\
\text { biocompression }\end{array}$ & $\rho_{\mathrm{s}}$ & solid density of MSW \\
\hline$\rho_{\mathrm{s}}$ & solid density of MSW & $\rho_{s}^{*}$ & initial specific density of MSW solids \\
\hline
\end{tabular}




\section{INTRODUCTION}

Settlement of municipal solid waste (MSW) commonly is separated into three compression processes: (1) immediate compression, (2) mechanical creep, and (3) biocompression (El-Fadel and Khoury 2000; Hossain et al. 2003; Marques et al. 2003; Gourc et al. 2010; Bareither et al. 2012a). Immediate compression is stress-dependent and occurs rapidly with an increase in vertical stress. Mechanical creep and biocompression are timedependent processes that occur under constant vertical stress. Mechanical creep involves physical yielding and reorientation of MSW components, whereas biocompression is attributed to anaerobic decomposition of the MSW organic fraction. After biodegradation of the organic waste fraction is exhausted, MSW compression will continue as mechanical creep of the residual waste (i.e., final mechanical creep).

Conceptual models of MSW settlement for scenarios of (i) inhibited and (ii) complete organic waste decomposition are shown in Fig. 1. The two settlement curves in Fig. 1 are drawn with respect to laboratory- and field-scale testing of MSW (e.g., Bareither et al. 2010; Gourc et al. 2010; Bareither et al. 2012a) and apply to a given MSW composition under the same constant vertical stress. The lower-bound settlement curve applies to a scenario where MSW decomposition is inhibited (e.g., dry, conventional landfill) and settlement primarily is attributed to physical compression processes of immediate compression and mechanical creep. The upper-bound settlement curve applies to a scenario where MSW decomposition is optimized (e.g., anaerobic bioreactor landfill) such that organic waste is decomposed to the extent possible. An increase in total MSW settlement occurs with active biodegradation due to removal of solid mass. Settlement curves between the lower- and upper- bound curves shown in Fig. 1 exist for scenarios where a fraction of the MSW organic waste decomposes.

Settlement predictions of MSW require an applicable model and appropriate model parameters. Model parameterization typically is conducted with one or a combination of the following approaches: (1) field-scale data are analyzed to obtain best fit model parameters; (2) 
model parameters are obtained from laboratory experiments; or (3) model parameters are obtained from empirical relationships with waste characteristics (El-Fadel and Khoury 2000; Park et al. 2007; Bareither et al. 2013). Model parameterization techniques generally are discussed that accompany a given MSW settlement prediction; however, selecting an appropriate settlement model requires an understanding of how compression phases are represented mathematically as well as a comparison between available models to support model selection. A thorough review of MSW settlement modeling is presented in El-Fadel and Khoury (2000); however, MSW settlement modeling has been the focus of significant research since 2000 (e.g., Marques et al. 2003; Hossain and Gabr 2005; Machado et al. 2009; Babu et al. 2010; Chen et al. 2010; Gourc et al. 2010; Chen et al. 2012) and a comparison and discussion of currently available settlement models has not been conducted.

The objective of this study was to evaluate the performance and applicability of available MSW settlement models via analysis of field-scale data. Two field-scale case histories are used to evaluate model performance in regards to (1) conventional versus bioreactor landfill behavior (Yazdani et al. 2006) and (2) composite settlement as the summation of settlement of multiple waste lifts (Bareither et al. 2012b). Findings from these model simulations were used to develop guidance on model selection via comparison between available models. 


\section{MATHEMATICAL FORMULATIONS OF MSW COMPRESSION PROCESSES}

A common formulation for total MSW settlement $\left(S_{T}\right)$ is

$$
S_{T}=S_{I}+S_{T D}
$$

where $S_{\text {I }}$ is immediate settlement and $S_{T D}$ is time-dependent settlement, which can be further separated into the summation of settlement due to mechanical creep $\left(S_{M C}\right)$ and biocompression $\left(S_{B}\right)$ (i.e., $\left.S_{T D}=S_{M C}+S_{B}\right)$. These contributions of settlement typically are related as strain:

$$
S_{T}=H_{0} \cdot \varepsilon_{l}+H_{E O I}\left(\varepsilon_{M C}+\varepsilon_{B}\right)
$$

where $H_{0}$ is initial waste thickness prior to immediate compression, $H_{E O I}$ is waste thickness at the end-of-immediate compression, $\varepsilon_{l}$ is immediate compression strain, $\varepsilon_{\mathrm{MC}}$ is mechanical creep strain, and $\varepsilon_{B}$ is biocompression strain. Total settlement in Eq. 2 is related to two waste thicknesses (where $H_{E O I}=H_{0}-S_{l}$ ) for the following reasons: (1) separating MSW settlement into immediate and time-dependent processes is convenient and commonly performed for model parameterization; and (2) time-dependent model parameters computed based on strain relative to $H_{E O I}$ will be directly applicable in the event that immediate compression is not measured. Certain models developed or applied to MSW settlement relate all strain to $H_{0}$ (Gibson and Lo 1961; Marques et al. 2003; Babu et al. 2010), and in this study these models were applied directly as outlined in the original publications.

Most MSW settlement models employ similar mathematical functions for immediate compression, mechanical creep, and biocompression. The primary differences between models are the mathematical functions used and what compression processes they represent. The mathematical functions incorporated into the various settlement models initially are discussed in regards to the compression process they represent, and subsequently in regards to how the functions are combined to represent MSW settlement due to coupled compression processes. 


\section{Immediate Compression}

Immediate compression occurs due to an increase in vertical stress (e.g., MSW filling or final cover placement) and is shown as Phase 1 in Fig. 1. Commonly used parameters to estimate immediate compression include the following: (1) constrained modulus $(D)$, expressed as the ratio of change in vertical stress $\left(\sigma_{\mathrm{v}}\right)$ to change in vertical strain $\left(\varepsilon_{\mathrm{v}}\right)\left(D=\Delta \sigma_{\mathrm{v}} / \Delta \varepsilon_{\mathrm{v}}\right) ;$; $(2)$ coefficient of volume change $\left(m_{v}\right)$, which is equivalent to $1 / D ;(3)$ compression $\left(C_{c}{ }^{\prime}\right)$ and recompression $\left(C_{r}{ }^{\prime}\right)$ ratios, expressed as the ratio of change in vertical strain to change in logarithm of vertical stress $\left(C_{c}{ }^{\prime}\right.$ or $\left.C_{c}{ }^{\prime}=\Delta \varepsilon_{v} / \Delta \log \sigma_{v}\right)$; and (4) compression $(\lambda)$ and recompression $(\kappa)$ indices, expressed as the change in void ratio $(e)$ to change in natural logarithm of mean effective stress $\left(p^{\prime}\right)\left(\lambda\right.$ or $\left.\kappa=-\Delta e / \Delta \ln p^{\prime}\right)$. All parameters are commonly-used settlement parameters in soil mechanics, with the latter two approaches applicable to settlement related to either vertical strain or void ratio.

Application of $m_{v}$ and $D$ to estimate immediate compression of MSW are interchangeable, since $m_{v}=1 / D$, and can be applied as

$$
S_{l}=H_{0} \cdot \varepsilon_{l}=H_{0} \cdot \Delta \sigma_{v} \cdot m
$$

where $\Delta \sigma_{v}$ is the change in vertical stress for which immediate compression occurs. Beaven and Powrie (1996) report that $D$ increases with an increase in applied stress and waste density. Thus, $m_{v}$ would decrease with increasing stress and waste density, which indicates that both parameters are stress-dependent. Therefore, predicting immediate compression via $m_{v}$ or $D$ requires that parameters are measured and applied within known stress ranges.

The most broadly adopted approach for computing $S_{l}$ is based on $C_{c}$ :

$$
S_{l}=H_{0} \cdot C_{c}^{\prime} \cdot \log _{10}\left(\frac{\sigma_{v o}+\Delta \sigma_{v}}{\sigma_{v o}}\right)
$$

where $\sigma_{\mathrm{vo}}$ is initial vertical stress prior to stress increase $\left(\Delta \sigma_{\mathrm{v}}\right)$ and is computed at the mid-depth of an MSW layer subjected to $\Delta \sigma_{\mathrm{v}}$. Use of $C_{c}{ }^{\prime}$ is common since a single $C_{c}{ }^{\prime}$ has been shown applicable for a broad range of vertical stress (e.g., Marques et al. 2003; Vilar and Carvalho 
2004; Bareither et al. 2012c). Immediate compression can also be related through void ratio (e), where $C_{c}=-\Delta e / \Delta \log \sigma_{v}=C_{c}{ }^{\prime}\left(1+e_{0}\right)$. However, void ratio can increase in MSW during compression due to decomposition of organic solid mass (e.g., McDougall and Pyrah 2004; Bareither et al. 2012c), which may confound application of a void ratio-based settlement parameter. Additionally, $C_{c}{ }^{\prime}$ can be estimated based on the waste compressibility index (WCl), which is a function of waste dry weight water content $\left(w_{d}\right)$, dry unit weight $\left(\gamma_{d}\right)$, and percent composition of organic waste (Bareither et al. 2012c). The ability to estimate $C_{c}{ }^{\prime}$ based on waste characteristics enhances the applicability of $C_{c}{ }^{\prime}$ for predicting immediate compression.

Recent MSW settlement modeling efforts (e.g., Machado et al. 2002; Babu et al. 2010) have adopted the use of $\lambda$ and $\kappa$ from critical state soil mechanics (Wood 1990) to represent immediate compression. In this approach, immediate compression is separated into elastic and plastic components as follows:

$$
S_{l}=H_{0} \cdot\left(\varepsilon_{e}+\varepsilon_{p}\right)=H_{0} \cdot\left[\frac{\lambda}{1+e} \cdot \ln \left(\frac{\sigma_{v o}+2 \Delta \sigma_{v}}{3 \sigma_{v o}}\right)+\left(\frac{\lambda-\kappa}{1+e}\right) \cdot \ln \left(\frac{M^{2}+\eta^{2}}{M^{2}}\right)\right]
$$

where $\varepsilon_{\mathrm{e}}$ is elastic strain, $\varepsilon_{\mathrm{p}}$ is plastic strain, and $M$ is the frictional constant estimated by the slope of the critical state line, which is equal to $6 \cdot \sin \phi /(2-\sin \phi)$ and $\phi$ is the internal friction angle. According to Wood (1990) and Machado et al. (2002), mean effective stress ( $p^{\prime}$ ) and preconsolidation stress $\left(p_{o}^{\prime}\right)$ used in the critical state formulation can be approximated by $\sigma_{\text {vo }}^{\prime}$ and $\Delta \sigma_{\mathrm{v}}^{\prime}$, where $p^{\prime}=\sigma_{\mathrm{vo}}+2 \Delta \sigma_{\mathrm{v}}^{\prime} / 3$ and $p_{o}^{\prime}=\sigma_{\mathrm{vo}}^{\prime}$. In this study, all vertical stresses within MSW are expressed as total stress and assumed equivalent to effective stress due to the field-scale experiments having free-drainage that prevented development of positive pore pressure. Machado et al. (2002) proposed separating MSW into fibrous and paste components that follow coupled elasto-plastic behavior, which they report yields appropriate estimation of immediate compression. 


\section{Time-Dependent Compression}

Time-dependent compression is attributed to mechanical creep and biodegradation of the organic fraction of MSW. There are three general approaches to modeling time-dependent compression: (1) applying unique mathematical functions to three individual compression phases (mechanical creep, biocompression, and final mechanical creep); (2) applying two mathematical functions to represent mechanical creep and biocompression; or (3) using a single mathematical formulation to represent all time-dependent compression. Each of these approaches has advantages and disadvantages, and the primary difference in modeling timedependent compression in regards to the first two approaches is how mechanical creep and biocompression are combined.

\section{Mechanical Creep}

Time-dependent compression due to mechanical creep (Phase 2 in Fig. 1) most commonly is estimated via (1) a mechanical creep compression ratio $\left(C_{\alpha M^{\prime}}\right)$, expressed as the ratio of change in strain to change in logarithm of time $\left(\Delta \varepsilon_{\mathrm{v}} / \Delta \log t\right)$, or (2) a rheological model that incorporates compression and rate parameters (Gibson and Lo 1961). The $C_{\alpha M}$ approach as applied to MSW was originally proposed by Sowers (1973) and later modified by Bjarngard and Edgers (1990). Time-dependent settlement due to mechanical creep $\left(S_{M C}\right)$ for a given time $(t)$ since final waste placement can be expressed as

$$
S_{M C}(t)=H_{E O I} \cdot C_{\alpha M}{ }^{\prime} \cdot \log \left(\frac{t}{t_{M}}\right)
$$

where $t_{M}$ is elapsed time for the transition from immediate compression to mechanical creep. A single $C_{\alpha M}$ ' can be applicable to all time-dependent MSW compression when biodegradation is negligible (Ivanova et al. 2008; Bareither et al. 2012a; Siddiqui et al. 2013).

The rheological model is adopted from Gibson and Lo (1961) and $S_{M C}$ is expressed as 


$$
S_{M C}(t)=H_{0} \cdot \Delta \sigma_{v} \cdot\left[b\left(1-e^{\left(-\frac{\lambda}{b}\right) t}\right)\right]
$$

where $b$ is the time-dependent compression parameter, $\lambda / b$ is the rate of time-dependent compression, and $t$ is time since $\Delta \sigma_{v}$ (e.g., final waste placement). The initial waste thickness $\left(H_{0}\right)$ is used in Eq. 7 for consistency with the original model developed by Gibson and Lo (1961) as well as waste settlement models (Marques et al. 2003; Babu et al. 2010) that integrate Eq. 7 into a full-composite model (i.e., model that includes mathematical functions to represent all unique compression phases).

\section{Biocompression}

Settlement due to biocompression (Phase 3 in Fig. 1) can be estimated based on analogous approaches to those for mechanical creep. Bjarngard and Edgers (1990) identified a transition in time-dependent MSW compression where an increase in the rate of compression is attributed to waste biodegradation. A similar expression to Eq. 5 can be written for $S_{B}$ as

$$
S_{B}(t)=H_{E O I} \cdot C_{\alpha B^{\prime}} \cdot \log \left(\frac{t}{t_{B}}\right)
$$

where $C_{\alpha B}$ is the biocompression ratio and $t_{B}$ is elapsed time for the transition from mechanical creep to biocompression. The biocompression ratio $\left(C_{\alpha B^{\prime}}\right)$ is computed identically to $C_{\alpha M^{\prime}}$ (i.e., $\left.\Delta \varepsilon_{\mathrm{v}} / \Delta \log t\right)$, but determined within the time period that biodegradation is active. The transition from mechanical creep to biocompression $\left(t_{B}\right)$ has been linked to a break in slope of timedependent compression plotted on a semi-logarithmic plot (e.g., Fig. 1), the onset of methane generation (e.g., Bareither et al. 2010a; Gourc et al. 2010), and a decrease in leachate volatile fatty acid concentration or chemical oxygen demand and corresponding increase in $\mathrm{pH}$ (e.g., Olivier and Gourc 2007; Ivanova et al. 2008; Bareither et al. 2012a; Bareither et al. 2013).

A biodegradation-induced compression model based on first-order kinetics is as follows:

$$
S_{B}(t)=H_{E O I} \cdot \varepsilon_{B I O} \cdot\left(1-e^{-k\left(t-t_{B}\right)}\right)
$$


where $\varepsilon_{\mathrm{BIO}}$ is total strain due to biodegradation, $k$ is the first-order decay coefficient, and $t$ is elapsed time since final waste placement (Park and Lee 1997; El-Fadel and Khoury 2000; Park and Lee 2002; Gourc et al. 2010). Applying Eq. 9 to time-dependent MSW compression can be executed via (1) coupling mechanical creep and biocompression such that mechanical creep is simulated as a continuous process and $\varepsilon_{\mathrm{B} \text { IO }}$ only applies to biodegradation-induced compression (e.g., Gourc et al. 2010; Siddiqui et al. 2013) or (2) decoupling time-dependent compression such that during the period of active biodegradation Eq. 9 is used to predict both mechanical creep and biocompression (Park and Lee 1997; El-Fadel et al. 1999). The former method is preferable for long-term predictions and is adopted herein; the latter method is instructive for determining time at which biocompression ends to estimate $t_{F}$ in Fig. 1 (Bareither et al. 2013).

\section{Final Mechanical Creep}

As shown in Fig. 1, there is a transition in the rate of waste compression that follows completion of biocompression. Although this transition has been documented in laboratory experiments (Bareither et al. 2013), there is a lack of field-scale data documenting this change due to long time durations necessary to capture the transition. The main approach to predict final mechanical creep is to employ $C_{\alpha M F}$ s similar to Eq. 6 for the time period following the transition from biocompression to final mechanical creep ( $t_{F}$ in Fig. 1). The inclusion or omission of final mechanical creep in the various coupled modeling approach is described subsequently.

\section{Empirical Models}

Empirical models have been applied as single mathematical functions to represent complete time-dependent settlement (El-Fadel and Khoury 2000). Common mathematical functions used to for MSW settlement include logarithmic, power creep, and hyperbolic functions. Parameters for these models are site specific and settlement data are required to obtain relevant model parameters. 
Logarithmic Model. Yen and Scanlon (1975) present a logarithmic model to predict timedependent settlement assuming the MSW settlement rate decreases linearly with logarithm of the median fill age of the waste. Time-dependent settlement is computed as

$$
S_{T D}(t)=H_{E O I} \cdot\left\{\alpha+\frac{\beta}{\ln (10)} \cdot\left[\ln \left(t-\frac{t_{c}}{2}\right)-1\right]\right\}\left(t-\frac{t_{c}}{2}\right)
$$

where $\alpha$ and $\beta$ are fitting parameters corresponding to settlement rate coefficients and $t_{c}$ is the elapsed time for construction corresponding to duration of MSW filling (Ling et al. 1998; El-Fadel and Khoury 2000; Park et al. 2007). A limitation for using this model is $t \leq t_{c}+10^{(-\alpha / \beta)}$, which indicates that the settlement rate should be greater than or equal to zero. If the settlement rate is negative, expansion is predicted, which will not occur under constant vertical stress. The fitting parameter $\alpha$ is positive whereas $\beta$ is negative to satisfy a linearly decreasing settlement rate with logarithm of time (Ling et al. 1998; Park et al. 2007).

Power Creep Law. The power creep law is a relationship for time-dependent deformation under constant stress represented by transient creep behavior (Edil et al. 1990; Ling et al. 1998; Park et al. 2007). Total time-dependent MSW settlement is computed as

$$
S_{T D}(t)=H_{E O I} \cdot \Delta \sigma_{v} \cdot M\left(\frac{t}{t_{r}}\right)^{N}
$$

where $M$ is reference compressibility, $N$ is rate of compression, and $t_{r}$ is reference time, which typically is taken as $1 \mathrm{~d}$ to make time dimensionless.

Hyperbolic Function. Tan et al. (1991) present a hyperbolic function for representing MSW settlement that has been applied to cases such as settlement of an embankment on soft-ground where geomaterial properties are difficult or impossible to determine (Tan et al. 1991; Ling et al. 
1998; El-Fadel and Khoury 2000; Park et al. 2007). Time-dependent MSW settlement is computed with the following hyperbolic equation:

$$
S_{T D}(t)=\frac{t}{1 / \rho_{o}+t / S_{u l t}}
$$

where $\rho_{o}$ is initial rate of settlement, $S_{u l t}$ is ultimate settlement as time approaches infinity, and $t$ is elapsed time since monitoring began. Settlement data are required to determine $\rho_{\mathrm{o}}$ and $S_{\text {ult }}$ via model simulation. The hyperbolic function primarily is applicable to a time-dependent process, and thus, immediate settlement generally is not included. 


\section{COMPOSITE SETTLEMENT MODELS}

Composite MSW settlement models constructed to represent multiple phases of MSW compression (Fig. 1) combine different mathematical formulations from those described in the previous section. A summary of relevant MSW settlement parameter ranges for all composite settlement models is in Table 1.

\section{Gibson and Lo (1961)}

Gibson and Lo (1961) present the following rheological model that couples immediate and time-dependent compression:

$$
S_{T}(t)=H_{0} \cdot \Delta \sigma_{v} \cdot\left[a+b \cdot\left(1-e^{\left(-\frac{\lambda}{b}\right) t}\right)\right]
$$

where $a$ is analogous to $m_{v}$ in Eq. 3. This model is a combination of Eqs. 3 and 7 . One caveat with the Gibson and Lo model is the use of $H_{0}$ for computing both immediate and timedependent compression strain.

The Gibson and Lo model was originally developed for soil settlement, and timedependent compression is representative of a single process (i.e., mechanical creep). Edil and Dhowian (1979) expanded the Gibson and Lo model to include a tertiary compression component for predicting settlement in peat:

$$
S_{T}(t)=H_{0} \cdot \Delta \sigma_{v} \cdot\left[a+b \cdot\left(1-e^{\left(-\frac{\lambda}{b}\right) t}\right)+b_{1} \cdot\left(1-e^{\left(-\frac{\lambda_{1}}{b_{1}}\right)\left(t-t_{k}\right)}\right)\right]
$$

where $b_{1}$ and $\lambda_{1}$ are compression parameters for the tertiary compression process and $t_{k}$ is the transition time for onset of the tertiary process. Although this expanded model may be applicable to simulating three unique compression phases in MSW (i.e., immediate, mechanical creep, and biocompression), the original Gibson and Lo model (Eq. 13) was used in this study. 


\section{Sowers (1973); Bjarngard and Edgers (1990); Hossain and Gabr (2005)}

The primary components of the compression model presented in Sowers (1973) and Bjarngard and Edgers (1990) are based on commonly-used parameters to predict settlement in soils (e.g., $C_{c}{ }^{\prime}$ and $C_{\alpha}{ }^{\prime}$ ). A complete version of the model that accounts for immediate compression as well as all three possible phases of time-dependent compression (Fig. 1) is presented in Hossain and Gabr (2005) as

$$
S_{T}(t)=H_{0} \cdot C_{c}^{\prime} \log \left(\frac{\sigma_{v o}+\Delta \sigma_{v}}{\sigma_{v o}}\right)+H_{E O I}\left[C_{\alpha M}{ }^{\prime} \log \left(\frac{t}{t_{M}}\right)+C_{\alpha B}{ }^{\prime} \log \left(\frac{t}{t_{B}}\right)+C_{\alpha M F}{ }^{\prime} \log \left(\frac{t}{t_{F}}\right)\right]
$$

where Eqs. 4, 6, and 8 are combined with an additional term for final mechanical creep. Application of this model for long-term MSW settlement predictions requires a transition from $C_{\alpha B}{ }^{\prime}$ to $C_{\alpha M F}{ }^{\prime}$ since biocompression will not occur indefinitely (Bareither et al. 2013). For practical purposes $C_{\alpha M F}{ }^{\prime}$ can be assumed equal to $C_{\alpha M^{\prime}}$. Temporal terms for compression indices on the right hand side of Eq. 15 can be specified for the duration each process is active (e.g., $t_{B} \leq t \leq t_{F}$ for biocompression). For scenarios where biodegradation is not active (e.g., inhibited waste decomposition in Fig. 1), time-dependent compression can be represented with a single $C_{\alpha M^{\prime}}$.

Marques et al. (2003)

Marques et al. (2003) present the following composite MSW settlement model:

$$
S_{T}(t)=H_{0}\left[C_{c}^{\prime} \log \left(\frac{\sigma_{v o}+\Delta \sigma_{v}}{\sigma_{v o}}\right)+b \Delta \sigma\left(1-e^{-c t^{\prime}}\right)+\varepsilon_{B I O}\left(1-e^{-k t^{\prime \prime}}\right)\right]
$$

which combines immediate compression, mechanical creep, and biocompression strain that are all related to $H_{0}$. Marques et al. (2003) indicate that $t^{\prime}$ is time since stress increase $\left(\Delta \sigma_{v}\right)$ and $t^{\prime \prime}$ is time since placement of MSW. In regards to general MSW landfill operations and behavior (Fig. 1), $t^{\prime}$ is analogous to $t$ in previous equations as MSW settlement should be related to the prior stress increase $\left(\Delta \sigma_{v}\right)$. Also, waste decomposition may not initiate immediately following 
waste placement; thus, replacing $t^{\prime \prime}$ with $\left(t-t_{B}\right)$ allows for a lag time between waste placement and the onset of biodegradation. The Marques model applied in this study is in Eq. 17.

$$
S_{T}(t)=H_{0}\left[C_{c}^{\prime} \log \left(\frac{\sigma_{v o}+\Delta \sigma_{v}}{\sigma_{v o}}\right)+b \Delta \sigma\left(1-e^{-c t}\right)+\varepsilon_{B I O}\left(1-e^{-k\left(t-t_{B}\right)}\right)\right]
$$

Machado et al. (2009)

Machado et al. (2009) propose an MSW settlement model for time-dependent compression due to mechanical creep and biodegradation. This model combines $S_{M C}$ from Eq. 6 and $S_{B}$ based on the assumption that MSW is separated into fibrous material, composed primarily of plastic constituents, and paste, which includes all other MSW materials and the liquid phase. Although the model for $S_{B}$ is based on Eq. 9, a more sophisticated formulation is presented in Machado et al. (2009) to integrate mass loss due to biodegradation.

The change in biocompression strain $\left(d \varepsilon_{b}\right)$ as related to methane generation and mass loss in MSW is expressed as follows:

$$
d \varepsilon_{b}=\left\{\frac{\rho_{s}^{*} L_{o}(1+w) k}{\rho^{*}{ }_{p} C_{m}\left(1+e_{o}\right)} e^{-k t}\left[1+\alpha \frac{L_{o}(1+w)\left(1-e^{-k t}\right)}{C_{m}}\right]\right\} d t
$$

where $\rho_{s}^{*}$ is initial density of MSW solid material, $\rho_{p}^{*}$ is initial density of MSW paste, $L_{o}$ is methane generation potential $\left(\mathrm{m}^{3}-\mathrm{CH}_{4} / \mathrm{Mg}\right.$-dry $\left.\mathrm{MSW}\right)$, and $C_{m}$ is organic matter methane potential $\left(\mathrm{m}^{3}-\mathrm{CH}_{4} / \mathrm{Mg}\right.$-dry organic MSW). Integrating Eq. 18 with respect to time and combining with Eq. 6 to represent $S_{M C}$ yields

$$
S_{T D}(t)=H_{E O I} C_{\alpha M}^{\prime} \log \left(\frac{t}{t_{M}}\right)+H_{E O} \frac{\rho_{s}^{*} L_{o}(1+w)}{\rho_{p}^{*} C_{m}\left(1+e_{o}\right)}\left\{\left[1+\frac{\alpha^{*} L_{o}(1+w)}{C_{m}}\right]\left(1-e^{-k t}\right)-\frac{\alpha^{*} L_{o}(1+w)}{2 C_{m}}\left(1-e^{-2 k t}\right)\right\}
$$

which is used to compute settlement due to mechanical creep and biodegradation with a function to account for methane generation. A detailed derivation of Eq. 19 is in Appendix A. 
Babu et al. (2010)

Babu et al. (2010) include four assumptions in their MSW settlement modeling approach: (1) immediate compression of MSW follows elasto-plastic behavior (Eq. 5); (2) stress-strain response of MSW is fibrous; (3) mechanical creep can be expressed by Eq. 7; and (4) biocompression is represented by a first-order rate process (Eq. 9). The complete settlement model presented in Babu et al. (2010) is Eq. 20.

$$
S_{T}(t)=H_{0}\left[\frac{\lambda}{1+e} \ln \left(\frac{\sigma_{v O}+2 \Delta \sigma_{v}}{3 \sigma_{v o}}\right)+\left(\frac{\lambda-\kappa}{1+e}\right) \ln \left(\frac{M^{2}+\eta^{2}}{M^{2}}\right)+b \Delta \sigma\left(1-e^{-c t}\right)+\varepsilon_{B I O}\left(1-e^{-k\left(t-t_{B}\right)}\right)\right](20)
$$

The first two terms on the right-hand-side of the Eq. 20 correspond to immediate compression and the last two terms correspond to time-dependent processes of mechanical creep and biocompression. A detailed derivation of Eq. 20 is in Appendix A.

\section{Chen et al. (2010)}

Chen et al. (2010) present the following settlement model that combines Eq. 4 for immediate compression and Eq. 9 for all time-dependent compression:

$$
S_{T}(t)=H_{0} \cdot C_{c}^{\prime} \log \left(\frac{\sigma_{v o}+\Delta \sigma_{v}}{\sigma_{v o}}\right)+H_{E O I} \varepsilon_{M B}\left(1-e^{-c_{t} \cdot t}\right)
$$

where $\varepsilon_{\mathrm{MB}}$ is ultimate strain due to mechanical creep and biocompression and $c_{t}$ is a first-order rate coefficient for coupled mechanical creep and biocompression. Thus, time-dependent compression is simplified in this model to one first-order rate process.

\section{Gourc et al. (2010)}

The time-dependent waste settlement model presented in Gourc et al. (2010) combines Eqs. 6 and 9 to predict settlement based on $C_{\alpha M^{\prime}}$ and $k$ as shown in Eq. 22.

$$
S_{T D}(t)=H_{E O I}\left[C_{\alpha M} \cdot \log \left(\frac{t}{t_{M}}\right)+\varepsilon_{B I O}\left(1-e^{-k\left(t-t_{B}\right)}\right)\right]
$$


This model has also been employed by Siddiqui et al. (2013), who further demonstrate the effectiveness of predicting coupled settlement due to mechanical creep and biocompression. Gourc et al. (2010) recommend computing an initial estimate of $\varepsilon_{\mathrm{BIO}}$ as

$$
\varepsilon_{B I O}=\left(\gamma_{d} / \gamma_{s O}\right) \cdot C
$$

where $\gamma_{d}$ is dry unit weight at initiation of mechanical creep, $\gamma_{\text {so }}$ is dry unit weight of the solid organic fraction (assumed equal to $8.34 \mathrm{kN} / \mathrm{m}^{3}$ ), and $c$ is the ratio of solid organic mass to total dry waste mass. The parameter $c$ also can be related to methane generation; however, relating $c$ to waste composition is beneficial to estimate $\varepsilon_{\mathrm{BIO}}$ a priori.

\section{Chen et al. (2012)}

Chen et al. (2012) present an MSW settlement model based on unsaturated consolidation theory (Fredlund and Hasan 1979). This model is applicable for all compression processes (Fig. 1), and volumetric strain is related to changes in excess pore gas pressure $\left(u_{a}\right)$. The spatial and temporal change in $u_{a}$ is presented in Liu et al. (2006) for MSW as follows:

$$
u_{a}(z, t)=\sum_{n=0}^{\infty}\left[\frac{4 u_{o}}{(2 n+1) \pi} e^{-\lambda_{n} t}+\frac{4 B}{(2 n+1) \pi\left(\lambda_{n}-k\right)}\left(e^{-k t}-e^{-\lambda_{n} t}\right)\right] \sin (p z)
$$

where $\lambda_{n}=A p^{2}, A$ is the air phase compression coefficient, $B$ is a constant related to organic waste biodegradation, $p=\frac{(2 n+1) \pi}{2 H_{0}}$, and $u_{0}$ is initial pore gas pressure. Eq. 24 is used to express the change in discharged gas volume as a function of compression due to mechanical creep $\left(e^{-\lambda_{n} t}\right)$ and biodegradation $\left(e^{-k t}\right)$.

Total volumetric strain can be estimated by the following equation:

$$
\varepsilon_{T}(z, t)=m_{3}\left[u_{a}(z, t)-u_{0}\right]+\frac{M_{s o}}{\rho_{s} V_{o}}\left(1-e^{-k t}\right)
$$

where $m_{3}$ is the coefficient of gas volume change, $M_{s o}$ is mass of biodegradable waste, and $\rho_{\mathrm{s}}$ is 
density of the MSW solids. Total time-dependent settlement can be computed using Eq. 26, assuming one-dimensional compression and summing settlement along a vertical profile consisting of multiple waste layers.

$$
S_{T}(t)=H_{0} \sum_{z=1}^{H_{0}} m_{3}\left\{\left[\sum_{n=1}^{\infty}\left(\frac{4 u_{o}}{(2 n+1) \pi} e^{-\lambda_{n} t}+\frac{4 B}{(2 n+1) \pi\left(\lambda_{n}-k\right)}\left(e^{-k t}-e^{-\lambda_{n} t}\right)\right) \sin (p z)-u_{0}\right]+\frac{M_{s o}}{\rho_{s} V_{o}}\left(1-e^{-k t}\right)\right\}
$$

A detailed derivation of Eq. 26 is in Appendix A. 


\section{FIELD-SCALE LANDFILL DATA Yolo County Pilot Project}

The Yolo County Pilot Project (Yolo) included a Control and Enhanced cell constructed to similar dimensions (i.e., surface area and waste thickness) and filled with waste of similar composition and water content (Mehta et al. 2002; Yazdani et al. 2006). Average waste properties of the Control and Enhanced cells are presented in Table 2. A detailed initial waste characterization was not conducted; however, waste samples collected from the Control cell during operation contained $16.3 \%$ cellulose, $5.0 \%$ hemicellulose, and $17.2 \%$ lignin, on average (Mehta et al. 2002). Waste was compacted in lifts to replicate full-scale landfill operations. Green waste was used as interim cover between successive waste lifts to target a uniform permeability to promote liquid distribution throughout the waste. A geomembrane cover was placed over both cells after waste filling was complete to enhance gas collection.

Average waste thickness and average waste settlement for the Control and Enhanced cells are shown in Fig. 2. Surface elevations of the geomembrane covers were measured periodically during landfill operation to monitor settlement. An average waste thickness and corresponding settlement were computed for each elevation survey, which included more than 20 survey points on each landfill cell. The first survey was conducted seven months following final waste placement $(t=235 \mathrm{~d})$. Leachate recirculation was conducted in the Enhanced cell to accelerate waste decomposition; leachate recirculation was not conducted in the Control cell. Thus, the difference in settlement between the Control and Enhanced cells (Fig. 2b) is attributed to increased waste decomposition in the Enhanced cell.

The elapsed time between waste placement and the first elevation survey $(t=235 \mathrm{~d})$ suggests that some fraction of waste settlement due to immediate compression and mechanical creep was not captured in the data (Fig. 2). The measured data are sufficient for evaluating the efficacy of time-dependent compression models in representing MSW behavior; however, an estimate of the initial waste thickness prior to any settlement $\left(H_{0}\right)$ and waste thickness at end-of- 
immediate compression $\left(H_{E O I}\right)$ are needed for implementation of all models. Thus, a multilayered immediate settlement $\left(S_{l}\right)$ analysis was conducted to $(1)$ evaluate the practicality of estimating $S$, via Eq. 4 and (2) justify an estimate of $H_{E O /}$ for use in subsequent time-dependent settlement analyses. Details of the multi-layered $S_{\text {I }}$ analysis are described subsequently.

\section{Deer Track Bioreactor Experiment}

The Deer Track Bioreactor Experiment (DTBE) was a field-scale experiment conducted in a drainage lysimeter (8.2-m height, 2.4-m diameter) to assess the physical, chemical, and biological response of MSW with leachate addition (Bareither et al. 2012b). A schematic of the DTBE is shown in Fig. 3a. Settlement was monitored via four settlement plates placed at different depths in the waste column. Settlement was measured during waste placement using a site level and measuring tapes affixed to each settlement rod, and after waste placement via position transducers connected to the top of each settlement rod (Bareither et al. 2012b).

Daily average waste settlement measured for each settlement plate is shown in Fig. 3b. Waste settlements are representative of the total waste thickness below a given settlement plate. Total waste settlement increased with increasing waste thickness for Plates 1, 2, and 3; however, total settlement measured for Plates 3 and 4 was comparable and suggests there may have been differential settlement within the waste column.

Daily average waste settlement for individual waste layers is shown in Fig. 3c. Individual waste layer settlement was computed as the difference between total settlement measured for adjacent plates. Similar settlement behavior was observed for waste layers (WL) 1, 2, and 3, which exhibit distinct phases of immediate compression, mechanical creep, and biocompression (Fig. 3c). Although immediate compression and mechanical creep were also observed for WL4, a pronounced transition from mechanical creep to biocompression was not observed. Bareither et al. (2012b) report waste decomposition throughout the waste column of the DTBE based on analysis of initial and final solid waste. The absence of a pronounced biocompression phase for 
WL4 may be attributed to a rigid waste structure that resisted void volume collapse following organic waste decomposition (e.g., McDougall and Pyrah 2004).

A summary of waste characteristics for each waste layer in the DTBE and the composite waste column is included in Table 3. Settlement models were applied to individual waste layers after initial filling (Fig. 3c, Table 3) to assess variation in model parameters that may be encountered in a given waste profile. Settlement predictions were then completed on individual waste layers considering the end-of-filling condition (Table 3 ) to assess the efficacy of summing individual waste layer settlement to predict composite settlement measured at the top of the waste column (i.e., composite waste profile). For this analysis, waste settlement occurred due to placement of the top gravel layer (Fig. 3a) and self-weight of the waste. Waste moisture content and solid waste chemical characteristics in Table 3 were measured on waste samples collected during filling (Bareither et al. 2012b).

\section{Settlement Model Implementation and Analysis}

A summary of the settlement models used in the analyses conducted herein is included in Table 4. Yolo settlement data were used to assess applicability of different settlement models in representing compression behavior for conventional (Control cell) and bioreactor (Enhanced cell) landfills. All settlement models listed in Table 4 were used in this exercise to encompass the breadth in MSW settlement modeling. The DTBE settlement data were used to evaluate the effectiveness of summing individual waste layer settlement to predict settlement of a composite waste profile. This composite settlement analysis is relevant to full-scale landfills that are filled sequentially in individual waste layers. The uniqueness of the DTBE assessment is that individual waste layer characteristics are known for the end-of-filling condition (Table 3) and total waste settlement of the composite waste column was measured (i.e., Plate 4 in Fig. 3b) such that predicted settlement can be compared to measured settlement. Settlement models used in the DTBE analysis were selected based on the Yolo assessment. 
Parameters included in the settlement models were differentiated into four categories: (1) measured, (2) fixed, (3) computed, and (4) optimized. The total number of model parameters and number of optimized parameters for each settlement model is included in Table 4. Measured parameters were based on initial waste properties or characteristics of the experiments. Fixed parameters were identified as parameters that could be constrained based on previous experience or fixed to simplify model simulations. Computed parameters were calculated based on measured and fixed parameters (e.g., e computed via $\gamma_{d}$ and $G_{s}$ ). Thus, measured, fixed, and computed parameters did not vary in a given model application. Optimized parameters were determined via least squares optimization in the model implementation procedure. Identification of the four model parameter categories for each settlement model is included with the tabulated model parameters in Tables 6 through 9.

Settlement model performance was evaluated via statistical assessment, practicality of model application, and extrapolation to represent future settlement. Statistical parameters include the coefficient of determination $\left(R^{2}\right)$ and average bias of the simulation. The practicality assessment included a comparison of the number of total and optimized parameters versus the statistical parameters. The extrapolation assessment was based on observation of anticipated settlement beyond the range of measured settlement. Extrapolating predictions to forecast long-term waste settlement is relevant to evaluate progression of organic waste stabilization, the duration of post-closure, and practicality of site reclamation (e.g., Sharma and De 2007; Abichou et al. 2013).

The coefficient of determination was computed as

$$
R^{2}=1-\frac{S S R}{S S T}
$$

where $S S R$ is sum of squared residuals and $S S T$ is total sum of squares. The total sum of squares was computed as

$$
S S T=\sum_{j=1}^{N}\left(S_{j}-\bar{S}_{j}\right)^{2}
$$


where $N$ is the number of observations in the data set, $S_{j}$ is measured settlement, and $\bar{S}_{j}$ is the arithmetic mean of all $S_{j}$. The sum of squared residuals was computed as

$$
S S R=\sum_{j=1}^{N}\left(S_{j}-\hat{S}_{j}\right)^{2}
$$

where $\hat{S}_{j}$ is modeled settlement that corresponds to measurement $S_{j}$. Average bias was computed as the arithmetic mean of the $N$ residuals $\left(S_{j}-\hat{S}_{j}\right)$ for a given data set. A positive average bias indicates that observed settlement is under-predicted (i.e., observed settlement > predicted settlement), whereas a negative average bias indicates that observed settlement is over-predicted. Procedures outlined in Berthouex and Brown (2002) were used as guidance for computing statistics for each set of observed and modeled data.

Model implementation was conducted in either Excel or MATLAB. Excel was used to the extent possible with the Solver function used to determine optimized parameters via least squares analysis. MATLAB was used to implement the model in Chen et al. (2012), which required multiple imbedded equations and numerous iterations to obtain the optimized parameters. All model parameter optimizations were conducted via minimizing the $S S R$.

\section{RESULTS}

\section{Yolo Immediate Settlement Analysis}

Waste settlement measured in the Yolo test cells (Fig. 2) can be attributed to mechanical creep and biocompression. A multi-layered $S_{/}$analysis was implemented for the Yolo test cells to evaluate an estimation method that can be applied in practice. This method was also used to estimate $H_{0}, S_{l}$, and $H_{E O I}$ for use in time-dependent settlement analyses.

A schematic of the multi-layered settlement analysis conducted for Yolo is shown in Fig. 4. This analysis included the following assumptions: (i) both cells were filled incrementally with 2-m-thick waste layers; (ii) immediate compression only occurs due to induced stress from waste placed on top of a previously deposited waste layer (i.e., self-weight settlement within a 
given waste layer is assumed negligible); and (iii) the same compression parameter (e.g., $C_{c}{ }^{\prime}$ ) is applicable for all waste layers. The first assumption is relevant for sequential landfilling of MSW that is typical of full-scale landfill operations. The second assumption reduces settlement computed for the top waste layer to zero as negligible stress increase is anticipated with placement of a geomembrane cover. The third assumption is based on observations that $C_{c}{ }^{\prime}$ approximately is constant over a broad stress range (e.g., Bareither et al. 2012c).

Implementation of the multi-layered $S_{l}$ analysis required waste thickness constraints to guide the analysis and aid in defining the number of waste layers for the Control and Enhanced cells. Waste thickness constraints included the measured thickness on Day $235\left(H_{235}\right)($ Fig. 4) and the maximum potential waste thickness prior to any settlement $\left(H_{0}\right)$. The waste thickness on Day 235 corresponds to the first elevation survey following waste placement; thus, the waste thickness on any previous day must be greater. The maximum potential waste thickness $\left(H_{0}\right)$ was computed as the product of the assumed individual waste layer thickness $\left(h_{0}\right)$ and number of waste layers $(n)$. This thickness, $H_{0}$, is theoretical as settlement will occur during filling and a waste thickness equal to $H_{0}$ will not actually be achieved. The waste thicknesses $H_{0}$ and $H_{235}$ impose constraints on the multi-layer $S_{\text {I }}$ analysis such that $H_{0}>H_{E O I}>H_{235}$.

The number of 2-m-thick waste layers selected for the settlement analysis in the Enhanced cell was eight, whereas nine layers were selected for the Control cell (Fig. 4). The additional waste layer included for the Control cell was due to a larger $\mathrm{H}_{235}$, which is consistent with a greater mass of waste in the Control cell (Table 2). The number of waste layers selected for each cell was constrained to be a whole number, and the anticipated magnitude of immediate compression strain was assumed to be in the range of 0.10 to 0.30 based on previous studies (e.g., Kavazanjian et al. 1999; Hossain et al. 2003; Olivier and Gourc 2007; Bareither et al. 2012c).

A target $S$, was estimated for both the Control and Enhanced cells based on extrapolating mechanical creep compression back to an anticipated time for completion of 
immediate compression ( $t_{M}$ in Fig. 1). Measured settlement in the Yolo test cells between Day 235 and Day 523 (i.e., second cover elevation survey, Fig. 2) can be attributed predominantly to mechanical creep due to methane generation and the onset of biocompression occurring approximately on Day 500 (Yazdani et al. 2006; Bareither et al. 2010). Thus, a mechanical creep ratio $\left(C_{\alpha M^{\prime}}\right)$ was computed for the Control and Enhanced cells between Days 235 and 523 and used to back-calculated anticipated settlement due to mechanical creep between $t_{M}$ and Day 235. For this analysis, $t_{M}$ was assumed equal to $15 \mathrm{~d}$ based on observations of field-scale immediate compression (Bareither et al. 2012c). Incorporating these assumptions and calculations leads to an estimate of $\mathrm{H}_{\mathrm{EOI}}$. The target $S$, is the difference between $\mathrm{H}_{0}$ and $\mathrm{H}_{E O \mathrm{I}}$.

A summary of three $S_{l}$ analyses and the corresponding compression parameters, $S_{l}$, and waste thickness is in Table 5. The three analyses pertain to the following considerations:

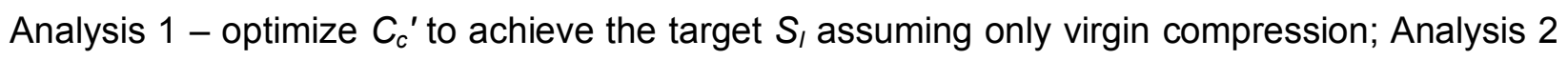
- compute $S_{\text {I }}$ with a $C_{c}{ }^{\prime}$ based on an empirical relationship with the waste compressibility index $(W C I)$; and Analysis 3 - assume $S_{\text {I }}$ is attributed to recompression and virgin compression and optimize the precompression stress $\left(\sigma_{\mathrm{vc}}\right)$ to achieve the target $S_{\text {I. }}$ In Analysis $3, C_{c}{ }^{\prime}$ was estimated from the $\mathrm{WCl}$ and the recompression ratio $\left(C_{r}{ }^{\prime}\right)$ was assumed equal to $1 / 10 \cdot C_{c}{ }^{\prime}$ based on data presented in Bareither et al. (2012c). The $\mathrm{WCl}$ is a function of dry weight water content $\left(w_{d}\right), \gamma_{d}$, and the percent contribution of organic waste (Bareither et al. 2012c). The contribution of organic waste was assumed equal to the U.S. national average (Staley and Barlaz 2009), and factoring in estimates of $w_{d}$ and $\gamma_{d}$ yielded $C_{c}{ }^{\prime}=0.232$.

Analysis 1 is a straight-forward parameter optimization procedure, whereas Analyses 2 and 3 build on current knowledge of MSW immediate compression behavior. The $C_{c}{ }^{\prime}$ determined for Analysis 1 was 0.196 for the Control cell and 0.154 for the Enhanced cell (Table 5). These $C_{c}{ }^{\prime}$ agree with past studies (Table 1) and are within the range of anticipated variation in $C_{c}{ }^{\prime}$ (two standard deviations) based on data compiled for the $W C /-C_{c}{ }^{\prime}$ relationship developed in Bareither et al. (2012c). Applying $C_{c}{ }^{\prime}=0.232$ in Analysis 2 leads to an over-estimation of $S_{l}$ in 
both cases as $H_{E O I}<H_{235}$, which is not possible. Applying $C_{c}{ }^{\prime}=0.232$ in Analysis 3 combined with the optimization of $\sigma_{\mathrm{vc}}$ leads to $\sigma_{\mathrm{vc}}=10 \mathrm{kPa}$ for the Control cell and $15 \mathrm{kPa}$ for the Enhanced cell (Table 5). Bareither et al. (2012c) reported an apparent $\sigma_{\mathrm{vc}}$ in laboratoryprepared MSW specimens due to compaction efforts required to achieve the target $\gamma_{d}$. Thus, the presence of a $\sigma_{v c}$ in a full-scale landfill due to compaction efforts is not unreasonable and

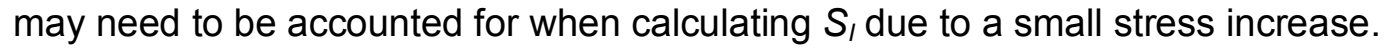

The multi-layered $S_{\text {I }}$ analysis outlined herein is applicable to estimate $S_{l}$ in solid waste landfills. Assumptions included in this analysis were based on relevant full-scale landfill operations or findings from recent studies on MSW compression behavior. Thus, the analysis

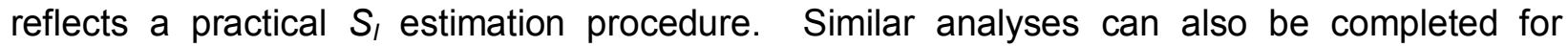
predicting $S$, based on Eqs. 3 and 5. However, the focus has been on Eq. 4 and the use of $C_{c}{ }^{\prime}$ as this method is more prevalent and is believed to be more applicable to landfill practitioners.

\section{Yolo Time-Dependent Settlement Analysis}

Temporal settlement data from the Control and Enhanced cells at Yolo and settlement model results are shown in Fig. 5. A summary of model parameters for the Yolo simulations and accompanying $R^{2}$ s are in Table 6 for full composite models and Table 7 for time-dependent models. Settlement models were implemented via a multi-layered analysis (Fig. 4), whereby settlements of individual waste layers were summed to yield total settlement. In general, all settlement models evaluated in this study capture compression behavior for the Control and Enhanced cells within the range of measured settlement. The $R^{2}$ s range from 0.832 to 0.971 for the Control cell and from 0.841 to 0.990 for the Enhanced cell. Coefficients of determination for the Enhanced cell generally are greater than those for the Control cell due to a broader range in measured settlement data, which leads to a larger SST and higher $R^{2}$.

All time-dependent simulations were implemented with the constraint that $S_{\text {, equals }}$ the

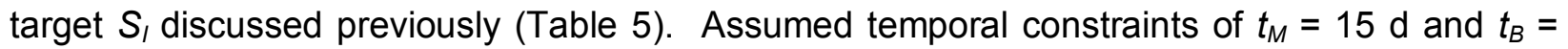
$500 \mathrm{~d}$ were included in all simulations, where applicable. These constraints were used to 
reduce the number of optimized model parameters, improve consistency between timedependent settlement simulations, and enhance model comparisons.

Extrapolating settlement models to elapsed times greater than the last elevation survey conducted on Day 3980 ( $t=10.9 \mathrm{yr}$ ) provides a means to evaluate the practicality of long-term performance of a given model. All settlement models, except for the logarithmic and power creep models, provide reasonable extrapolations of MSW settlement to $t=100 \mathrm{yr}$ (Fig. 5). Extrapolation of these empirical models does not agree with anticipated long-term MSW settlement (Fig. 1) and will lead to an overestimation of future settlement (Figs. 5c and 5d). Thus, these two empirical models are considered non-representative of actual compression behavior in MSW landfills and may lead to uncertainty in long-term settlement predictions.

Extrapolation of all other models in Fig. 5 will lead to either a finite magnitude of settlement or a constant rate of final mechanical creep on a semi-logarithmic plot. The constant rate of final mechanical creep is apparent in the Sowers, Machado, and Gourc models (Figs. 5b, $5 \mathrm{~h}$, and $5 \mathrm{k})$, and is attributed to the use of $C_{\alpha M}$ to represent mechanical creep. In contrast, the Gibson and Lo, Park and Lee, Marques, Babu, Chen-2010, and Chen-2012 all approach a finite magnitude of settlement near $t=100 \mathrm{yr}$ (Fig. 5). These models incorporate constraints on the magnitude of mechanical creep (Eq. 7) and/or biocompression (Eq. 9). The long-term settlement behavior in MSW landfills has not been adequately measured due to long monitoring requirements. However, predictions of MSW settlement with models that constrain settlement to a finite value may lead to under-predictions, whereas models that include a constant rate of final mechanical creep may lead to over-predictions. Use of multiple models may be useful to identify a range of anticipated in long-term MSW settlement (e.g., Bareither et al. 2013).

The hyperbolic model also includes a finite value of potential long-term settlement (i.e., $S_{\text {ult }}$. Although this model appears to yield practical long-term settlement extrapolations (Fig. $5 e)$, the hyperbolic model is difficult to implement in the absence of measured settlement data 
that are required for parameterization. These limitations suggest that the hyperbolic model may not be applicable for predicting MSW settlement.

Relationships of $R^{2}$ versus the total number of model parameters and number of optimized model parameters for the Control and Enhanced cells are shown in Fig. 6. The majority of the settlement models yielded $R^{2}>0.95$, indicating that these models are capable of explaining greater than $95 \%$ of the variation in the time-dependent settlement data. This level of statistical significance was anticipated due to the parameter optimization procedure used in the simulation exercise. Data shown in Fig. 6 suggest that the majority of the settlement models are capable of simulating unique compression phases in both conventional (Control cell) and bioreactor (Enhanced cell) landfills.

All settlement models with the exception of the three empirical models and the Park and Lee model were used in the subsequent DTBE settlement modeling exercise. Although these four omitted models can lead to statistically significant settlement simulations (Tables 6 and 7), the other available models are believed more applicable due to encompassing a broader range of settlement behavior and including model parameters that have physical significance. The Park and Lee model primarily is applicable to biocompression and is incorporated in the Marques, Machado, Gourc, and Babu models to represent the biocompression phase. Also, the Chen-2010 model uses the Park and Lee formulation to simulate complete time-dependent settlement (Eq. 23). Thus, omission of the Park and Lee model in the DTBE analysis primarily is due incorporation of this model in other settlement models.

\section{DTBE Settlement Simulation and Prediction}

Settlement measured in the DTBE (Fig. 3) can be attributed to immediate compression, mechanical creep, and biocompression. Measured settlement and model simulations for Waste Layer 1 (WL1) in the DTBE are shown in Fig. 7. Similar plots for the other three waste layers are included in Appendix C. A summary of model parameters for the DTBE simulations and 
accompanying $R^{2}$ s are in Table 8 for full composite settlement models and Table 9 for timedependent settlement models. Full composite settlement models that incorporate all three phases of compression behavior (i.e., Gibson and Lo, Sowers, Marques, Babu, Chen-2010, and Chen-2012; Table 4) were implemented directly to simulate behavior reflected in the DTBE data. Immediate compression, computed with a $C_{c}{ }^{\prime}$ (Eq. 4), was added to all time-dependent models (i.e., Machado, Gourc; Table 4) such that these models also were applicable to simulating settlement due to immediate compression, mechanical creep, and biocompression. Temporal constraints of $t_{M}=15 \mathrm{~d}$ and $t_{B}=164 \mathrm{~d}$ were included to reduce the number of optimized parameters. These time constraints are based on temporal behavior observed in the DTBE (Bareither et al. 2012b).

Settlement models, whereby optimized parameters were obtained via least squares analysis, are shown as solid lines in Fig. 7. In general, all settlement models fit to the DTBE data for WL1 (Fig. 7) and the other three waste layers (Appendix C) display the ability to capture measured settlement behavior under different applied vertical stress. Dashed lines in Fig. 7 are settlement predictions based on applying average, optimized model parameters based on the four waste layers simulated in the DTBE (Tables 8 and 9). There exists greater difference between measured settlement and the predictions as compared to the model fits due to variation in settlement for the four waste layers in the DTBE (Fig. 3c).

The largest difference between measured settlement data for WL1 in the DTBE and the settlement predictions based on average, optimized model parameters was observed for the Gibson and Lo, Marques, and Babu models (Fig. 7). The Gibson and Lo model (Eq. 13) includes the coefficient of volume compressibility $\left(a\right.$ or $m_{v}$ ) and time-dependent compression parameter $(b)$ that are both multiplied by the increase in vertical stress $\left(\Delta \sigma_{v}\right)$. Mechanical creep is modeled in the Marques (Eq. 16) and Babu (Eq. 22) models with the time-dependent component of the Gibson and Lo model. Thus, $\Delta \sigma_{v}$ has direct influence on settlement model parameters and calculated settlement for these three models. 
Relationships of $a$ and immediate compression strain versus $\Delta \sigma_{v}$ are shown in Fig. 8a for the Gibson and Lo model. The coefficient of volume compressibility decreases with increasing applied stress (Fig. 8a), which is consistent with observations from large-scale compression tests conducted by Beaven and Powrie (1996). The actual immediate compression strain in the DTBE (simulated strain in Fig. 8a) displayed a modest increasing trend with increasing $\Delta \sigma_{\mathrm{v}}$; however, applying a single, average a (Table 8) to all waste layers leads to an overestimation of immediate compression at higher $\Delta \sigma_{v}$ and underestimation of immediate compression at lower $\Delta \sigma_{v}$ (predicted strain in Fig. 8a). Thus, a stress-dependent function for a may need to be integrated into the Gibson and Lo model to predict $S_{i}$ for waste layers subjected to different $\Delta \sigma_{\mathrm{v}}$. The vertical offset between the measured settlement and settlement prediction for the Marques and Babu models was attributed to variation in the immediate compression parameters (Table 8). A similar, but smaller vertical offset of measured versus predicted settlement is noticed for all models in Fig. 7, which also is attributed to variation in immediate compression parameters among the four waste layers (Table 8).

The relationship between $b$ and $\Delta \sigma_{v}$ is shown in Fig. $8 \mathrm{~b}$ for the Gibson and Lo, Marques, and Babu models. Although scatter exists in the $b$ parameter with respect to $\Delta \sigma_{v}$, there is no definitive trend that suggests $b$ has similar stress-dependent behavior compared to $a$. The variation in $b$ with respect to $\Delta \sigma_{\mathrm{v}}$ is a function of the magnitude of time-dependent settlement simulated for the four waste layers. Both the Marques and Babu models incorporate the same mathematical functions for mechanical creep and biocompression, which supports the similar magnitude of $b$ for both models (Fig. 8b). However, the Gibson and Lo model was implemented with a single mathematical function to represent all time-dependent compression due to mechanical creep and biocompression. Thus, the $b$ parameters for the Gibson and Lo simulations generally are larger relative to the other two models, which reflect a greater magnitude of simulated settlement. 
The normalized difference between model parameters optimized for each WL in the DTBE and the arithmetic average DTBE model parameter (Tables 8 and 9 ) is shown in Fig. 9. The normalization was completed with respect to the average DTBE parameters and allows for comparison among model parameters of varying order of magnitude. Normalized differences > 0 indicate that WL-specific parameters are larger than the DTBE average, whereas normalized differences $<0$ indicate the opposite. The median (i.e., center line of the box) for each WL lies within \pm 0.2 ; however, parameter sets for WL1 and WL4 are biased negative, indicating a greater prevalence of smaller model parameters relative to the average, whereas the parameter set for WL2 is biased positive, indicating a greater prevalence of larger model parameters relative to the average. This comparison suggests that variability in model parameters exists within a controlled experiment designed to be representative of field conditions. The variation is attributed to different compression behavior measured for the four waste layers (Fig. 3c).

Settlement measured for the composite waste column in the DTBE and multi-layer settlement predictions are shown in Fig. 10. Data in Fig. 10 are representative of settlement measured at the top of the waste column (Plate 4 in Figs. 3a and 3b). Settlement model results in Fig. 10 include two analyses: Model Fit - optimized parameters determined for individual waste layers were used to estimate settlement for the respective waste layers that was then summed to represent total waste settlement; and Prediction - settlement for each waste layer was estimated using average, optimized DTBE model parameters and then settlement of the four waste layers was summed to represent total waste settlement. The Model Fit was anticipated to fit the measured data well based on the use of waste-layer specific parameters. The Prediction was used to evaluate the efficacy of using a single set of model parameters in a multi-layered settlement analysis to predict waste settlement attributed to immediate compression, mechanical creep, and biocompression.

The overall settlement behavior measured in the DTBE was captured effectively by all eight models using average, optimized DTBE model parameters (Prediction, Fig. 10). In no 
cases was settlement under-predicted; however, a modest over-prediction was obtained for the Gibson and Lo, Marques, Babu, Chen-2010, and Chen-2012 models. This over-prediction primarily was attributed to overestimating immediate compression for certain waste layers (Fig. 7 and Appendix $\mathrm{C}$ ), and decreasing the predicted $S_{i}$ in all models would lead to an improved fit to measured data. As discussed previously, the Gourc, Sowers, and Machado models will all lead to continuous increasing settlement with time due to inclusion of $C_{\alpha M}$, whereas the remainder of the models constrain long-term settlement to a finite magnitude. 


\section{SETTLEMENT MODEL RECOMMENDATIONS}

Municipal solid waste settlement models were evaluated with respect to statistical significance, practicality of model application, and extrapolation to represent future settlement. The overall statistical performance for a settlement model should have a high $R^{2}$ and low absolute value of average bias. Practicality of the model application can be ascertained with regards to the number of model parameters (total and optimized) required to achieve a settlement prediction for a given level of statistical performance. Extrapolation of future settlement can be qualitatively evaluated via observing long-term settlement behavior.

An ideal settlement model for application in practice should be straight-forward to implement, include the ability to represent immediate compression, mechanical creep, and biocompression, and include physically-significant model parameters. Although a case may be made that all settlement models used in the DTBE analysis are applicable for practice, the Gourc model can be argued to be the most practical. This model includes a low number of total and optimized model parameters (Table 4), has the ability to represent a broad range of compression behavior (Figs. $5 \mathrm{k}, 7 \mathrm{~g}$, and $10 \mathrm{~g}$ ), and model parameters can be related to waste characteristics (Bareither et al. 2013) and gas generation behavior (Gourc et al. 2010). In addition, immediate compression can be added onto the model to expand modeling capabilities to all three compression processes.

The Machado and Sowers model also are relevant to adoption in practice. The Sowers model has been used extensively since Sowers (1973) first applied general soil mechanics principles to solid waste. One significant challenge with the Sowers model is defining the elapsed time for transition from biocompression to final mechanical creep $\left(t_{F}\right.$ in Fig. 1). This elapsed time can be identified via a dual-model approach as discussed in Bareither et al. (2013); however, identifying elapsed times for transitions in compression behavior is a challenge in MSW settlement modeling. The Machado model has similar advantages to the Gourc model. 
The one limitation of the Machado model is the inclusion of twice as many model parameters as the Gourc model (Table 4) to achieve a prediction with similar statistical performance.

The Gibson and Lo and Chen-2010 model, as implemented, both combine timedependent compression due to mechanical creep and biocompression into a single mathematical function. This combination is convenient to reduce the number of total and optimized model parameters (Table 4), but limits the ability to uniquely represent different compression behavior anticipated during mechanical creep and biocompression. The Gibson and Lo model was shown to yield inaccurate predictions of immediate settlement due to the stress-dependent nature of the model parameters (Fig. 8a). Also, both the Gibson and Lo and Chen-2010 models constrain settlement to a finite value. Thus, these models may not provide the robustness necessary to predict settlement due to multiple compression processes.

The Marques and Babu models employ similar mathematical functions for mechanical creep and biocompression, but use different soil mechanics parameters to represent immediate compression. The Marques model incorporates a $C_{c}{ }^{\prime}$ to predict immediate compression, which has been used widely in MSW research and practice. The Babu model uses a critical state soil mechanics framework to simulate immediate compression due to plastic and elastic deformation. The benefit of the critical state framework introduced in the Babu model was not

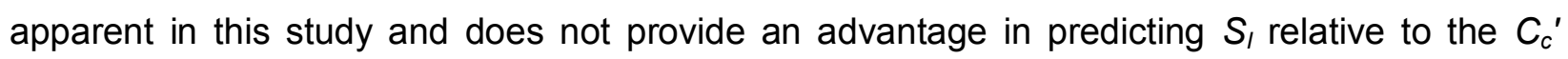
approach.

Finally, the Chen-2012 model was difficult to implement and included the highest number of model parameters (Table 4). The increase in number of model parameters did not improve the settlement prediction in the DTBE relative to the other models (Fig. 10). An improved fit likely could have been obtained via increasing the number of optimized model parameters; however, this approach is not ideal and may lead to model parameters that have limited physical significance. Overall, the unsaturated consolidation theory used to develop the Chen-2012 model does not provide advantages relative to the other settlement models. 


\section{SUMMARY AND CONCLUSIONS}

An evaluation of MSW settlement model performance and applicability has been conducted based on analysis of field-scale data: (1) Yolo Co. Pilot Project (Yolo), which included a Control and Enhanced cell, and (2) Deer Track Bioreactor Experiment (DTBE), which included four settlement plates at varying waste depths. Yolo data were used to assess a multilayer immediate settlement analysis and applicability of the models to represent compression behavior representative of conventional landfills where biodegradation is limited (Control cell) and bioreactor landfills with leachate recirculation to enhance biodegradation (Enhanced cell). The DTBE data were separated into four waste layers with unique settlement behavior. These data were simulated to assess variation in model parameters within a controlled field-scale experiment. Also, a prediction of composite waste settlement in the DTBE was completed via applying average DTBE model parameters to each waste layer and summing settlement to represent overall settlement of the composite waste column.

The multi-layer immediate settlement analysis developed for Yolo provides a framework for completing immediate settlement analyses to estimate the initial waste thickness and waste thickness at end-of-immediate compression. The immediate compression ratio $\left(C_{c}{ }^{\prime}\right)$ optimized to yield the target immediate settlement $\left(C_{c}{ }^{\prime}=0.15\right.$ to 0.20$)$ was less than the $C_{c}{ }^{\prime}$ predicted from available empirical relationships $\left(C_{c}{ }^{\prime}=0.23\right)$. A precompression stress of $10 \mathrm{kPa}$ (Control cell) and $15 \mathrm{kPa}$ (Enhanced cell) was computed that yielded the target immediate settlement with $C_{c}{ }^{\prime}$ $=0.23$ and recompression ratio $=1 / 10 \cdot C_{c}{ }^{\prime}$. A precompression stress should be included when using empirical estimates of $C_{c}{ }^{\prime}$ to predict immediate settlement under small vertical stress (e.g., less than $15 \mathrm{kPa})$.

Simulation of the Control and Enhanced cells with all settlement models via least squares optimization yielded high coefficient of determinations $\left(R^{2}>0.83\right)$ and accurate fits within the range of measured data. The power creep and logarithmic empirical models did not accurately reflect long-term settlement behavior and can lead to overestimates of MSW 
settlement. In general, empirical models (power creep, logarithmic, and hyperbolic) are not recommended for use in MSW settlement modeling due to non-representative MSW behavior, limited physical significance of model parameters, and the requirement of measured data to determine model parameters.

The coefficient of compressibility ( $m_{v}$, or a in Gibson and Lo model) is stress-dependent and applying a single parameter to waste layers under different vertical stress can lead to inaccurate estimates of immediate settlement. Models that combine mechanical creep and biocompression into a single mathematical function (i.e., Gibson and Lo and Chen-2010) are formulated to constrain total time-dependent settlement to a single process and finite magnitude, which limits model applicability. Overall, all other models used in this analysis, which either have the capability to simulate complete MSW compression behavior (Sowers, Marques, Babu, Chen-2012) or where an immediate compression component can be added onto the model (Gourc and Machado), were shown to provide accurate simulations and predictions of field-scale datasets.

Settlement models (Gourc, Machado, and Sowers) that include a mechanical creep compression ratio $\left(C_{\alpha M}\right)$ yield continuous settlement for long-term extrapolations, whereas all other models include mathematical functions that constrain long-term settlement to a finite magnitude. Inclusion of $C_{\alpha M}$ may lead to over-estimates of long-term settlement, whereas models that omit this parameter and constrain settlement due to mechanical creep may lead to under-estimates of long-term settlement. Predicting settlement with multiple models is recommended to capture anticipated bounds in long-term MSW settlement.

The Gourc model included the lowest number of total and optimized model parameters and yielded high statistical performance for the DTBE prediction $\left(R^{2}=0.99\right)$. In addition, model parameters included in the Gourc model have been shown to have physical significance (e.g., Gourc et al. 2010; Bareither et al. 2013) such that parameters can be estimated from waste characteristics and empirical relationships. Overall, the Gourc model was found to be the most 
applicable and straightforward to implement and is recommended for use in practice. The other models that included unique mathematical functions for immediate compression, mechanical creep, and biocompression (Machado, Sowers, Marques, Babu, and Chen-2012) are all capable of yielding satisfactory MSW simulations and predictions; however, additional model parameters or constraints are necessary to implement these models. 
Table 1. Summary of ranges for settlement model parameters.

\begin{tabular}{|c|c|c|c|}
\hline Model & Parameter & Unit & Range (Average) \\
\hline \multirow{3}{*}{ Gibson \& Lo (1961) } & $a$ & $1 / \mathrm{kPa}$ & $5.32 \times 10^{-7}-3.80 \times 10^{-4}\left(1.90 \times 10^{-4}\right)$ \\
\hline & $\mathrm{b}$ & $1 / \mathrm{kPa}$ & $0.0001-0.0095(0.0048)$ \\
\hline & $\lambda / \mathrm{b}$ & $1 / \mathrm{yr}$ & $0.0336-15.3(7.67)$ \\
\hline \multirow{5}{*}{ Marques et al. (2003) } & $\mathrm{C}_{\mathrm{c}}^{\prime}$ & - & $0.073-0.28(0.18)$ \\
\hline & $\mathrm{b}$ & $1 / \mathrm{kPa}$ & $0.0001-0.0095(0.0048)$ \\
\hline & $\mathrm{c}$ & $1 / \mathrm{yr}$ & $0.0336-15.3(7.67)$ \\
\hline & $\varepsilon_{\mathrm{BIO}}$ & - & $0.0016-0.44(0.22)$ \\
\hline & $\mathrm{k}$ & $1 / \mathrm{yr}$ & $0.245-17.9(9.07)$ \\
\hline \multirow{4}{*}{$\begin{array}{c}\text { Sowers (1973); } \\
\text { Bjarngard and Edgers } \\
\text { (1990); Hossain and } \\
\text { Gabr (2005) }\end{array}$} & $\mathrm{C}_{\mathrm{c}}^{\prime}$ & - & $0.073-0.28(0.18)$ \\
\hline & $\mathrm{C}_{\alpha \mathrm{M}^{\prime}}$ & - & $0.017-0.1(0.059)$ \\
\hline & $\mathrm{C}_{a \mathrm{~B}^{\prime}}$ & - & $0.057-0.36(0.21)$ \\
\hline & $\mathrm{C}_{\alpha M F}{ }^{\prime}$ & - & $0.008-0.22(0.11)$ \\
\hline \multirow{3}{*}{ Machado et al. (2009) } & $\mathrm{C}_{\alpha \mathrm{M}^{\prime}}$ & - & $0.017-0.10(0.059)$ \\
\hline & $\alpha^{*}$ & - & $1.40-102(51.7)$ \\
\hline & $\mathrm{k}$ & $1 / \mathrm{yr}$ & $0.245-17.9(9.07)$ \\
\hline \multirow{5}{*}{ Babu et al. (2010) } & $\lambda$ & - & $0.091-0.18(0.13)$ \\
\hline & $\mathrm{b}$ & $1 / \mathrm{kPa}$ & $0.0001-0.0095(0.0048)$ \\
\hline & $\mathrm{C}$ & $1 / \mathrm{yr}$ & $0.0336-15.3(7.67)$ \\
\hline & $\varepsilon_{\mathrm{BIO}}$ & - & $0.0016-0.44(0.22)$ \\
\hline & $\mathrm{k}$ & $1 / \mathrm{yr}$ & $0.245-17.9(9.07)$ \\
\hline \multirow{3}{*}{ Chen et al. (2010) } & $\mathrm{C}_{\mathrm{c}}{ }^{\prime}$ & - & $0.073-0.28(0.18)$ \\
\hline & $\varepsilon_{\mathrm{MB}}$ & - & $0.098-0.24(0.17)$ \\
\hline & $\mathrm{C}_{\mathrm{t}}$ & $1 / \mathrm{yr}$ & $0.1-0.365(0.233)$ \\
\hline \multirow{3}{*}{ Gourc et al. (2010) } & $\mathrm{C}_{\alpha \mathrm{M}^{\prime}}$ & - & $0.017-0.1(0.059)$ \\
\hline & $\mathrm{k}$ & $1 / \mathrm{yr}$ & $0.245-17.9(9.07)$ \\
\hline & $\varepsilon_{\mathrm{BIO}}$ & - & $0.0016-0.44(0.22)$ \\
\hline \multirow{3}{*}{ Chen et al. (2012) } & $\mathrm{k}$ & $1 / \mathrm{yr}$ & $0.245-17.9(9.07)$ \\
\hline & $\mathrm{k}_{\mathrm{a}}$ & $\mathrm{m} / \mathrm{yr}$ & $3.65-54.8(29.2)$ \\
\hline & $m_{3}$ & $\mathrm{~m}^{2} / \mathrm{N}$ & $-10^{-6}-10^{-7}\left(-4.5 \times 10^{-7}\right)$ \\
\hline
\end{tabular}

Compiled from Fredlund and Hasan (1979), Edil et al. (1990), Lang and Tchobanoglous (1995), Park and Lee (2002), Marques et al. (2003), McDougall and Pyrah (2004), Park et al. (2007), Sharma and De (2007), Babu et al. (2010), Chen et al. (2010), Gourc et al. (2010), Bareither et al. (2012a), and Bareither et al. (2013). 
Table 2. Average waste properties of the Control and Enhanced cells, Yolo Co. Pilot Project (Mehta et al. 2002; Yazdani et al. 2006)

\begin{tabular}{l|c|c}
\hline \hline Property & Control Cell & Enhanced Cell \\
\hline Surface area $\left(\mathrm{m}^{2}\right)$ & 930 & 930 \\
\hline Dry weight water content $(\%)$ & 20.3 & 20.3 \\
\hline Total initial mass $(\mathrm{Mg})$ & 7,932 & 7,772 \\
\hline Green waste $(\%)$ & 16.7 & 15.6 \\
\hline Approximate initial total unit weight $\left(\mathrm{kN} / \mathrm{m}^{3}\right)$ & 7.0 & 7.0 \\
\hline Average waste thickness on Day $235(\mathrm{~m})^{\mathrm{a}}$ & 15.0 & 13.6 \\
\hline \hline
\end{tabular}

${ }^{2}$ Day 235 = first elevation survey; thickness is averaged from more than 20 surface elevation measurements on each cell. 
Table 3. Waste properties of Deer Track Bioreactor Experiment for waste layers after initial filling (prior to subsequent waste placement) and waste layers at the end-of-filling (prior to placement of final gravel layer) (Bareither et al. 2012b).

\begin{tabular}{c|c|c|c|c|c|c|c|c|c|c}
\hline \hline $\begin{array}{c}\text { Waste } \\
\text { State }\end{array}$ & $\begin{array}{c}\text { Waste } \\
\text { Layer }\end{array}$ & $\begin{array}{c}\mathrm{H} \\
(\mathrm{m})\end{array}$ & $\begin{array}{c}\mathrm{w} \\
(\%)\end{array}$ & $\begin{array}{c}\gamma_{\mathrm{t}} \\
\left(\mathrm{kN} / \mathrm{m}^{3}\right)\end{array}$ & $\begin{array}{c}\sigma_{\circ} \\
(\mathrm{kPa})\end{array}$ & $\begin{array}{c}\Delta \sigma \\
(\mathrm{kPa})\end{array}$ & $\begin{array}{c}\text { Cellulose } \\
(\%)\end{array}$ & $\begin{array}{c}\text { Hemi- } \\
\text { Cellulose } \\
(\%)\end{array}$ & $\begin{array}{c}\text { Lignin } \\
(\%)\end{array}$ & $\begin{array}{c}\text { Volatile } \\
\text { Solids } \\
(\%)\end{array}$ \\
\hline \multirow{4}{*}{$\begin{array}{c}\text { Initial } \\
\text { Filling }\end{array}$} & 1 & 1.80 & 33.0 & 9.16 & 8.26 & 48.7 & 17.0 & 4.6 & 30.8 & 49.1 \\
\cline { 2 - 12 } & 3 & 2.23 & 26.4 & 6.29 & 7.03 & 33.4 & 14.7 & 4.0 & 24.5 & 42.6 \\
\cline { 2 - 12 } & 4 & 1.76 & 40.8 & 7.42 & 6.5 & 6.5 & 28.4 & 6.7 & 28.3 & 62.0 \\
\hline \multirow{2}{*}{$\begin{array}{c}\text { End } \\
\text { of }\end{array}$} & 1 & 1.47 & 33.0 & 11.25 & 48.7 & 19.5 & 17.0 & 4.6 & 30.8 & 49.1 \\
\cline { 2 - 12 } & 2 & 1.87 & 26.4 & 7.53 & 33.4 & 19.5 & 14.7 & 4.0 & 24.5 & 42.6 \\
\hline & 1.74 & 31.7 & 7.60 & 19.7 & 19.5 & 18.3 & 6.2 & 31.4 & 57.9 \\
\hline
\end{tabular}

Notes: $\mathrm{H}=$ waste thickness; $\mathrm{w}=$ dry-weight water content; $\gamma_{\mathrm{t}}=$ total unit weight, $\sigma_{\mathrm{vo}}=$ initial vertical stress, computed at mid-depth of a given waste layer; $\Delta \sigma_{v}=$ increase in vertical stress 
Table 4. Summary of waste settlement models used for simulations.

\begin{tabular}{|c|c|c|c|c|c|c|c|}
\hline \multicolumn{2}{|c|}{ Model Name } & $\begin{array}{l}\text { Eq. } \\
\text { No. }\end{array}$ & $\begin{array}{l}\text { Phases } \\
\text { Included }^{\mathrm{a}}\end{array}$ & $\begin{array}{c}\text { Total } \\
\text { Parameters }\end{array}$ & $\begin{array}{l}\text { Optimized } \\
\text { Parameters }\end{array}$ & $\begin{array}{l}\text { Optimized } \\
\text { Variables }\end{array}$ & References \\
\hline \multirow{6}{*}{$\begin{array}{l}\frac{0}{0} \\
\frac{0}{0} \\
\frac{0}{2} \\
0 \\
\frac{1}{0} \\
0 \\
\frac{0}{0} \\
\frac{0}{0} \\
0 \\
\bar{J} \\
\overline{1}\end{array}$} & Gibson and Lo & 13 & $\mathrm{IM}, \mathrm{MC}, \mathrm{BIO}$ & 5 & 3 & $a, b$, and $\lambda / b$ & Gibson \& Lo (1961) \\
\hline & Sowers & 15 & $\mathrm{IM}, \mathrm{MC}, \mathrm{BIO}$ & 11 & 4 & $\begin{array}{l}\mathrm{C}_{\mathrm{c}}^{\prime}, \mathrm{C}_{\alpha M^{\prime}}, \mathrm{C}_{\alpha \mathrm{B}^{\prime}} \\
\quad \text { and } \mathrm{C}_{\mathrm{\alpha MF}}\end{array}$ & $\begin{array}{l}\text { Sowers (1973); Bjarngard \& } \\
\text { Edgers (1990); Hossain \& } \\
\text { Gabr (2005) }\end{array}$ \\
\hline & Marques & 17 & $\mathrm{IM}, \mathrm{MC}, \mathrm{BIO}$ & 10 & 5 & $\begin{array}{l}\mathrm{C}_{\mathrm{c}}^{\prime}, \mathrm{b}, \mathrm{c}, \varepsilon_{\mathrm{BIO}} \\
\text { and } \mathrm{k}\end{array}$ & $\begin{array}{l}\text { Sowers (1973); Gibson \& Lo } \\
\text { (1961); Park \& Lee (1997); } \\
\text { Marques et al. (2003) }\end{array}$ \\
\hline & Babu & 20 & $\mathrm{IM}, \mathrm{MC}, \mathrm{BIO}$ & 13 & 7 & $\begin{array}{c}\lambda, \kappa, \eta, b, c, \varepsilon_{\mathrm{BIO}} \\
\text { and } \mathrm{k}\end{array}$ & $\begin{array}{l}\text { Gibson \& Lo (1961); Park \& } \\
\text { Lee (1997); Babu et al. (2010) }\end{array}$ \\
\hline & Chen-2010 & 21 & $\mathrm{IM}, \mathrm{MC}, \mathrm{BIO}$ & 7 & 3 & $\mathrm{C}_{\mathrm{c}}^{\prime}, \varepsilon_{\mathrm{MB}}$ and $\mathrm{C}_{\mathrm{t}}$ & $\begin{array}{l}\text { Sowers (1973); Chen et al. } \\
(2010)\end{array}$ \\
\hline & Chen-2012 & 26 & $\mathrm{IM}, \mathrm{MC}, \mathrm{BIO}$ & 22 & 4 & $\mathrm{u}_{\mathrm{o}}, \mathrm{k}, \mathrm{k}_{\mathrm{a}}$, and $\mathrm{m}_{3}$ & $\begin{array}{l}\text { Park \& Lee (1997); Chen et al. } \\
\text { (2012) }\end{array}$ \\
\hline \multirow{6}{*}{ 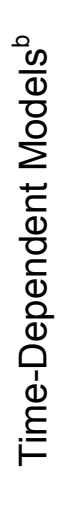 } & Park and Lee & 9 & $\mathrm{BIO}$ & 3 & 2 & $\varepsilon_{\mathrm{BIO}}$ and $\mathrm{k}$ & Park \& Lee (1997) \\
\hline & Logarithmic & 10 & $\mathrm{MC}, \mathrm{BIO}$ & 4 & 2 & $\alpha$ and $\beta$ & Yen \& Scanlon (1975) \\
\hline & Power Creep & 11 & $\mathrm{MC}, \mathrm{BIO}$ & 5 & 2 & $\mathrm{M}$ and $\mathrm{N}$ & Edil et al. (1990) \\
\hline & Hyperbolic & 12 & $\mathrm{MC}, \mathrm{BIO}$ & 2 & 2 & $\rho_{\mathrm{o}}$ and $\mathrm{S}_{\text {ult }}$ & Tan et al. (1991) \\
\hline & Machado & 19 & $\mathrm{MC}, \mathrm{BIO}$ & 11 & 3 & $\mathrm{C}_{\mathrm{am}}{ }^{\prime}, \alpha^{*}$, and $\mathrm{k}$ & $\begin{array}{l}\text { Sowers (1973); Machado et } \\
\text { al. (2009) }\end{array}$ \\
\hline & Gourc & 22 & $\mathrm{MC}, \mathrm{BIO}$ & 6 & 3 & $\mathrm{C}_{\mathrm{aM}}{ }^{\prime}, \varepsilon_{\mathrm{BIO}}$ and $\mathrm{k}$ & $\begin{array}{l}\text { Park \& Lee (1997); Gourc et } \\
\text { al. (2010) }\end{array}$ \\
\hline
\end{tabular}

${ }^{\mathrm{a}} \mathrm{IM}=$ immediate compression, $\mathrm{MC}=$ mechanical creep, and $\mathrm{BIO}=$ biocompression.

${ }^{\mathrm{b}}$ Immediate compression ratio $\left(\mathrm{C}_{\mathrm{c}}{ }^{\prime}\right)$ used to determine $\mathrm{S}_{\mathrm{I}}$ for all time-dependent models.

Table 5. Summary of the multi-layer immediate compression analyses conducted for the Control and Enhanced cells at Yolo. 


\begin{tabular}{|c|c|c|c|c|c|c|c|c|c|}
\hline Analysis & Description & Cell & $\mathrm{C}_{\mathrm{c}}^{\prime}$ & $\mathrm{C}_{\mathrm{r}}^{\prime}$ & $\sigma_{\mathrm{vc}}(\mathrm{kPa})$ & $\mathrm{S}_{\mathrm{I}}(\mathrm{m})$ & $\varepsilon_{l}(\mathrm{~m} / \mathrm{m})$ & $\mathrm{H}_{\mathrm{EOI}}(\mathrm{m})$ & $\mathrm{H}_{235}(\mathrm{~m})$ \\
\hline & \multirow{2}{*}{$\begin{array}{l}\text { Only virgin compression, target } \\
\mathrm{S}_{\mathrm{l}} \text {, optimized } \mathrm{C}_{\mathrm{c}}{ }^{\prime}\end{array}$} & $\mathrm{C}$ & 0.196 & - & - & 2.96 & 0.164 & 15.04 & 15.0 \\
\hline & & $E$ & 0.154 & - & - & 1.95 & 0.122 & 14.05 & 13.6 \\
\hline & \multirow{2}{*}{$\begin{array}{l}\text { Only virgin compression, } \mathrm{C}_{c}{ }^{\prime}=f \\
(\mathrm{WCl}) \text {, estimate } \mathrm{S}_{\mathrm{I}}\end{array}$} & $\mathrm{C}$ & 0.232 & - & - & 3.50 & 0.194 & 14.50 & 15.0 \\
\hline & & $E$ & 0.232 & - & - & 2.93 & 0.183 & 13.07 & 13.6 \\
\hline & \multirow{2}{*}{$\begin{array}{l}\text { Recompression \& virgin } \\
\text { compression, } \mathrm{C}_{\mathrm{c}}{ }^{\prime}=f(\mathrm{WCl}), \mathrm{C}_{\mathrm{r}}{ }^{\prime}= \\
\mathrm{C}_{\mathrm{c}}{ }^{\prime} / 10 \text {, target } \mathrm{S}_{\mathrm{l}} \text {, optimize } \sigma_{\mathrm{vc}}\end{array}$} & C & 0.232 & 0.0232 & 10.2 & 2.96 & 0.164 & 15.04 & 15.0 \\
\hline & & $E$ & 0.232 & 0.0232 & 15.1 & 1.95 & 0.122 & 14.05 & 13.6 \\
\hline
\end{tabular}

Note: $C_{c}{ }^{\prime}=$ immediate compression ratio; $C_{r}{ }^{\prime}=$ recompression ratio, $\sigma_{v c}=$ pre-compression stress; $S_{I}=$ settlement due to immediate compression; $\varepsilon_{\mid}=$immediate compression strain; $\mathrm{WCI}=$ waste compressibility index; $\mathrm{C}=\mathrm{Control}$ cell; $\mathrm{E}=$ Enhanced cell; $-=$ not applicable. 
Table 6. Summary of model parameters and coefficients of determination for the full composite waste settlement models based on Yolo data.

\begin{tabular}{|c|c|c|c|c|c|}
\hline Model & Parameter & Unit & Type & Control Cell & Enhanced Cell \\
\hline \multirow{5}{*}{$\begin{array}{l}\text { Gibson and } \\
\text { Lo }\end{array}$} & $\mathrm{H}_{0}$ & $\mathrm{~m}$ & $\mathrm{M}$ & 18.0 & 16.0 \\
\hline & $a$ & $1 / \mathrm{kPa}$ & 0 & $2.93 \times 10^{-3}$ & $2.48 \times 10^{-3}$ \\
\hline & $\mathrm{b}$ & $1 / \mathrm{kPa}$ & 0 & $1.75 \times 10^{-3}$ & $4.05 \times 10^{-3}$ \\
\hline & $\lambda / b$ & $1 / \mathrm{yr}$ & 0 & 0.060 & 0.230 \\
\hline & $\mathrm{R}^{2}$ & - & $\mathrm{C}$ & 0.956 & 0.981 \\
\hline \multirow{8}{*}{ Sowers } & $t_{M}$ & $\mathrm{yr}$ & $\mathrm{F}$ & 0.041 & 0.041 \\
\hline & $t_{B}$ & $\mathrm{yr}$ & $\mathrm{F}$ & 1.370 & 1.370 \\
\hline & $t_{F}$ & $\mathrm{yr}$ & $\mathrm{O}$ & 10.955 & 7.902 \\
\hline & $\mathrm{C}_{\mathrm{c}}{ }^{\prime}$ & - & $\mathrm{O}$ & 0.196 & 0.154 \\
\hline & $\mathrm{C}_{\alpha \mathrm{M}^{\prime}}$ & - & $\mathrm{O}$ & 0.005 & 0.030 \\
\hline & $\mathrm{C}_{\alpha B^{\prime}}$ & - & $\mathrm{O}$ & 0.047 & 0.199 \\
\hline & $\mathrm{C}_{\mathrm{aMF}}{ }^{\prime}$ & - & 0 & 0.005 & 0.030 \\
\hline & $\mathrm{R}^{2}$ & - & C & 0.895 & 0.988 \\
\hline \multirow{6}{*}{ Marques } & $\mathrm{C}_{\mathrm{c}}{ }^{\prime}$ & - & $\mathrm{O}$ & 0.196 & 0.154 \\
\hline & $\mathrm{b}$ & $1 / \mathrm{kPa}$ & 0 & $1.06 \times 10^{-3}$ & $3.12 \times 10^{-3}$ \\
\hline & $\mathrm{C}$ & $1 / \mathrm{yr}$ & $\mathrm{O}$ & 0.069 & 0.196 \\
\hline & $\varepsilon_{\mathrm{BIO}}$ & - & 0 & 0.035 & 0.045 \\
\hline & $\mathrm{k}$ & $1 / \mathrm{yr}$ & $\mathrm{O}$ & 0.069 & 0.998 \\
\hline & $\mathrm{R}^{2}$ & - & $\mathrm{C}$ & 0.971 & 0.990 \\
\hline \multirow{13}{*}{ Babu } & $\gamma_{d}$ & $\mathrm{kN} / \mathrm{m}^{3}$ & $M$ & 6.0 & 6.0 \\
\hline & $\mathrm{G}_{\mathrm{s}}$ & - & $\mathrm{F}$ & 1.0 & 1.0 \\
\hline & $\phi$ & $\circ$ & $\mathrm{F}$ & 37.0 & 37.0 \\
\hline & $\lambda$ & - & 0 & 0.116 & 0.108 \\
\hline & $\kappa$ & - & 0 & 0.012 & 0.011 \\
\hline & $\eta$ & - & 0 & 1.81 & 2.40 \\
\hline & $\mathrm{b}$ & $1 / \mathrm{kPa}$ & 0 & $1.93 \times 10^{-3}$ & $3.48 \times 10^{-3}$ \\
\hline & $\mathrm{c}$ & $1 / \mathrm{yr}$ & 0 & 0.037 & 0.204 \\
\hline & $k$ & $1 / \mathrm{yr}$ & 0 & 0.008 & 0.023 \\
\hline & $\varepsilon_{\mathrm{BIO}}$ & - & 0 & 0.143 & 0.978 \\
\hline & $M$ & - & C & 1.51 & 1.51 \\
\hline & $\mathrm{e}$ & - & C & 0.648 & 0.648 \\
\hline & $\mathrm{R}^{2}$ & - & C & 0.971 & 0.989 \\
\hline \multirow{4}{*}{$\begin{array}{l}\text { Chen } \\
-2010\end{array}$} & $\mathrm{C}_{\mathrm{c}}{ }^{\prime}$ & - & O & 0.196 & 0.154 \\
\hline & $\varepsilon_{\mathrm{MB}}$ & - & $\mathrm{O}$ & 0.118 & 0.226 \\
\hline & $\mathrm{c}_{\mathrm{t}}$ & $1 / \mathrm{yr}$ & 0 & 0.058 & 0.230 \\
\hline & $\mathrm{R}^{2}$ & - & $\mathrm{C}$ & 0.960 & 0.972 \\
\hline
\end{tabular}

Note: $\mathrm{M}=$ measured parameter, $\mathrm{C}=$ computed parameter, $\mathrm{F}=$ fixed parameter, and $\mathrm{O}=$ optimized parameter. 
Table 6. Summary of model parameters and coefficients of determination for the full composite waste settlement models based on Yolo data (continued).

\begin{tabular}{|c|c|c|c|c|c|}
\hline Model & Parameter & Unit & Type & Control Cell & Enhanced Cell \\
\hline \multirow{23}{*}{$\begin{array}{l}\text { Chen } \\
-2012\end{array}$} & $\mathrm{H}_{0}$ & $\mathrm{~m}$ & $\mathrm{M}$ & 18 & 16 \\
\hline & $\mathrm{V}_{\mathrm{o}}$ & $\mathrm{m}^{3}$ & $M$ & 16723 & 14864 \\
\hline & w & $\%$ & $\mathrm{M}$ & 17.6 & 17.6 \\
\hline & $\mathrm{T}$ & ${ }^{\circ} \mathrm{K}$ & $\mathrm{M}$ & 302 & 311 \\
\hline & $g$ & $\mathrm{~m} / \mathrm{sec}^{2}$ & $\mathrm{M}$ & 9.81 & 9.81 \\
\hline & $\rho_{w}$ & $\mathrm{~kg} / \mathrm{m}^{3}$ & $\mathrm{M}$ & 1000 & 1000 \\
\hline & $\rho$ & $\mathrm{kg} / \mathrm{m}^{3}$ & $\mathrm{M}$ & 713.6 & 713.6 \\
\hline & $\mathrm{G}_{\mathrm{s}}$ & - & $\mathrm{F}$ & 1.0 & 1.0 \\
\hline & $\rho_{\mathrm{s}}$ & $\mathrm{kg} / \mathrm{m}^{3}$ & $\mathrm{~F}$ & 1000 & 1000 \\
\hline & $\varpi_{i}$ & $\mathrm{~kg} / \mathrm{mole}$ & $\mathrm{F}$ & 0.029 & 0.029 \\
\hline & $\omega_{b}$ & $\mathrm{~kg} / \mathrm{mole}$ & $\mathrm{F}$ & 0.03 & 0.03 \\
\hline & $\mathrm{k}$ & $1 / \mathrm{yr}$ & 0 & 0.048 & 0.283 \\
\hline & $\mathrm{k}_{\mathrm{a}}$ & $\mathrm{m} / \mathrm{yr}$ & 0 & 32.50 & 30.77 \\
\hline & $m_{3}$ & $\mathrm{~m}^{2} / \mathrm{N}$ & 0 & $-6.08 \times 10^{-5}$ & $-3.61 \times 10^{-5}$ \\
\hline & $\mathrm{u}_{0}$ & $\mathrm{~N} / \mathrm{m}^{2}$ & 0 & 3203 & 5674 \\
\hline & $\mathrm{n}$ & - & $\mathrm{C}$ & 0.393 & 0.393 \\
\hline & $S$ & $\%$ & $C$ & 33.3 & 31.3 \\
\hline & $\mathrm{R}$ & $\mathrm{N}^{*} \mathrm{~m} /\left(\mathrm{mole}^{*} \mathrm{~K}\right)$ & C & 8.314 & 8.314 \\
\hline & $r_{b}$ & $\%$ & $\mathrm{C}$ & 21.6 & 20.3 \\
\hline & $\mathrm{M}_{\text {so }}^{*}$ & $\mathrm{Mg}$ & $C$ & 7932 & 7772 \\
\hline & $\mathrm{M}_{\mathrm{so}}$ & $\mathrm{Mg}$ & C & 1713 & 1578 \\
\hline & $\mathrm{V}_{\mathrm{G}}$ & $\mathrm{m}^{3}$ & $\mathrm{C}$ & 4384 & 4014 \\
\hline & $\mathrm{R}^{2}$ & - & C & 0.958 & 0.953 \\
\hline
\end{tabular}

Note: $\mathrm{M}=$ measured parameter, $\mathrm{C}=$ computed parameter, $\mathrm{F}=$ fixed parameter, $\mathrm{O}=$ optimized parameter. 
Table 7. Summary of model parameters and coefficients of determination for the time-dependent waste settlement models based on Yolo data.

\begin{tabular}{|c|c|c|c|c|c|}
\hline Model & Parameter & Unit & Type & Control Cell & Enhanced Cell \\
\hline \multirow{4}{*}{$\begin{array}{l}\text { Park and } \\
\text { Lee }\end{array}$} & $\mathrm{H}_{\mathrm{EOI}}$ & $\mathrm{m}$ & $\mathrm{M}$ & 15.0 & 14.1 \\
\hline & $\varepsilon_{\mathrm{BIO}}$ & - & $\mathrm{O}$ & 0.102 & 0.226 \\
\hline & $\mathrm{k}$ & $1 / \mathrm{yr}$ & $\mathrm{O}$ & 0.070 & 0.230 \\
\hline & $\mathrm{R}^{2}$ & - & C & 0.955 & 0.972 \\
\hline \multirow{4}{*}{ Logarithmic } & $t_{c}$ & $\mathrm{yr}$ & $\mathrm{F}$ & 0.150 & 0.150 \\
\hline & $\alpha$ & $\mathrm{m} / \mathrm{yr}$ & 0 & $6.07 \times 10^{-3}$ & $3.25 \times 10^{-2}$ \\
\hline & $\beta$ & $\mathrm{m} / \mathrm{yr}$ & 0 & $-8.93 \times 10^{-4}$ & $-1.62 \times 10^{-2}$ \\
\hline & $\mathrm{R}^{2}$ & - & C & 0.967 & 0.841 \\
\hline \multirow{4}{*}{$\begin{array}{l}\text { Power } \\
\text { Creep }\end{array}$} & $t_{r}$ & $\mathrm{yr}$ & $\mathrm{F}$ & $2.74 \times 10^{-3}$ & $2.74 \times 10^{-3}$ \\
\hline & $M$ & $1 / \mathrm{kPa}$ & $\mathrm{O}$ & $5.65 \times 10^{-6}$ & $3.49 \times 10^{-5}$ \\
\hline & $\mathrm{N}$ & - & 0 & 0.592 & 0.577 \\
\hline & $\mathrm{R}^{2}$ & - & C & 0.832 & 0.932 \\
\hline \multirow{3}{*}{ Hyperbolic } & $\rho_{\circ}$ & $\mathrm{m} / \mathrm{yr}$ & $\mathrm{O}$ & 0.012 & 0.100 \\
\hline & $S_{\text {ult }}$ & $\mathrm{m}$ & $\mathrm{O}$ & 0.283 & 0.565 \\
\hline & $\mathrm{R}^{2}$ & - & $C$ & 0.953 & 0.966 \\
\hline \multirow{13}{*}{ Machado } & $\gamma_{d}$ & $\mathrm{kN} / \mathrm{m}^{3}$ & $M$ & 6.0 & 6.0 \\
\hline & $\rho_{\mathrm{s}}{ }^{*}$ & $\mathrm{Mg} / \mathrm{m}^{3}$ & $\mathrm{M}$ & 0.700 & 0.686 \\
\hline & $\rho_{p}^{*}$ & $\mathrm{Mg} / \mathrm{m}^{3}$ & $\mathrm{M}$ & 1.8 & 1.8 \\
\hline & $w$ & - & $\mathrm{M}$ & 0.176 & 0.176 \\
\hline & $L_{o}$ & $\mathrm{~m}^{3} / \mathrm{Mg}$ & $M$ & 27.9 & 63.1 \\
\hline & $t_{M}$ & $\mathrm{yr}$ & $\mathrm{F}$ & 0.041 & 0.041 \\
\hline & $\mathrm{G}_{\mathrm{s}}$ & - & $\mathrm{F}$ & 1.0 & 1.0 \\
\hline & $C_{m}$ & $\mathrm{~m}^{3} / \mathrm{Mg}$ & $\mathrm{F}$ & 450 & 450 \\
\hline & $C_{\alpha M^{\prime}}$ & - & 0 & 0.005 & 0.029 \\
\hline & $\alpha^{*}$ & - & 0 & 36.0 & 36.0 \\
\hline & $\mathrm{k}$ & $1 / \mathrm{yr}$ & 0 & 0.203 & 0.279 \\
\hline & $e_{o}$ & - & C & 0.648 & 0.648 \\
\hline & $\mathrm{R}^{2}$ & - & $C$ & 0.840 & 0.959 \\
\hline \multirow{7}{*}{ Gourc } & $\mathrm{H}_{\mathrm{EOI}}$ & $\mathrm{m}$ & $M$ & 15.0 & 14.1 \\
\hline & $t_{M}$ & $\mathrm{yr}$ & $F$ & 0.041 & 0.041 \\
\hline & $t_{B}$ & $\mathrm{yr}$ & $\bar{F}$ & 1.37 & 1.37 \\
\hline & $\mathrm{C}_{\alpha \mu^{\prime}}$ & - & 0 & 0.005 & 0.031 \\
\hline & $\mathrm{k}$ & $1 / \mathrm{yr}$ & 0 & 0.045 & 0.417 \\
\hline & $\overline{\varepsilon_{\mathrm{BIO}}}$ & - & 0 & 0.132 & 0.132 \\
\hline & $\mathrm{R}^{2}$ & - & C & 0.971 & 0.990 \\
\hline
\end{tabular}

Note: $\mathrm{M}=$ measured parameter, $\mathrm{C}=$ computed parameter, $\mathrm{F}=$ fixed parameter, and $\mathrm{O}=$ optimized parameter. 
Table 8. Summary of model parameters and coefficients of determination for the full composite waste settlement models based on DTBE data.

\begin{tabular}{|c|c|c|c|c|c|c|c|c|}
\hline Model & Parameter & Unit & Type & WL1 & WL2 & WL3 & WL4 & Ave. \\
\hline \multirow{6}{*}{$\begin{array}{l}\text { Gibson } \\
\text { and Lo }\end{array}$} & $\mathrm{H}_{0}$ & $\mathrm{~m}$ & $M$ & 1.80 & 2.23 & 2.00 & 1.76 & - \\
\hline & $\Delta \sigma$ & $\mathrm{kPa}$ & $M$ & 68.2 & 52.9 & 39.2 & 19.5 & - \\
\hline & $a$ & $1 / \mathrm{kPa}$ & 0 & $3.18 \times 10^{-3}$ & $4.34 \times 10^{-3}$ & $5.15 \times 10^{-3}$ & $9.35 \times 10^{-3}$ & $5.50 \times 10^{-3}$ \\
\hline & $b$ & $1 / \mathrm{kPa}$ & 0 & $3.21 \times 10^{-3}$ & $3.72 \times 10^{-3}$ & $8.61 \times 10^{-3}$ & $3.54 \times 10^{-3}$ & $4.77 \times 10^{-3}$ \\
\hline & $\lambda / b$ & $1 / \mathrm{yr}$ & 0 & 0.659 & 1.19 & 0.506 & 2.43 & 1.20 \\
\hline & $R^{2}$ & - & $\mathrm{C}$ & 0.991 & 0.968 & 0.981 & 0.851 & 0.878 \\
\hline \multirow{11}{*}{ Sowers } & $\sigma_{\mathrm{o}}$ & $\mathrm{kPa}$ & $\mathrm{M}$ & 8.3 & 7.0 & 6.6 & 6.5 & - \\
\hline & $\Delta \sigma$ & $\mathrm{kPa}$ & $M$ & 68.2 & 52.9 & 39.2 & 19.5 & - \\
\hline & $t_{M}$ & $\mathrm{yr}$ & $\mathrm{F}$ & 0.041 & 0.041 & 0.041 & 0.041 & - \\
\hline & $t_{B}$ & $\mathrm{yr}$ & $\mathrm{F}$ & 0.449 & 0.449 & 0.449 & 0.449 & - \\
\hline & $t_{F}$ & $\mathrm{yr}$ & 0 & 2.37 & 1.56 & 2.98 & 2.71 & 2.41 \\
\hline & $\mathrm{C}_{\mathrm{c}}^{\prime}$ & - & 0 & 0.228 & 0.270 & 0.240 & 0.289 & 0.257 \\
\hline & $\mathrm{C}_{\alpha M^{\prime}}$ & - & $\mathrm{O}$ & 0.051 & 0.054 & 0.066 & 0.069 & 0.060 \\
\hline & $\mathrm{C}_{\mathrm{aB}}{ }^{\prime}$ & - & $\mathrm{O}$ & 0.231 & 0.275 & 0.310 & 0.033 & 0.212 \\
\hline & $\mathrm{C}_{\mathrm{aMF}}{ }^{\prime}$ & - & 0 & 0.051 & 0.054 & 0.066 & 0.069 & 0.060 \\
\hline & $\mathrm{H}_{\mathrm{EOI}}$ & $\mathrm{m}$ & $\mathrm{C}$ & 1.41 & 1.67 & 1.60 & 1.46 & - \\
\hline & $\mathrm{R}^{2}$ & - & $C$ & 0.990 & 0.984 & 0.974 & 0.879 & 0.999 \\
\hline \multirow{6}{*}{ Marques } & $\mathrm{C}_{\mathrm{c}}{ }^{\prime}$ & - & $\mathrm{O}$ & 0.232 & 0.269 & 0.244 & 0.304 & 0.262 \\
\hline & $\mathrm{b}$ & $1 / \mathrm{kPa}$ & $\mathrm{O}$ & $2.19 \times 10^{-3}$ & $1.58 \times 10^{-3}$ & $7.33 \times 10^{-3}$ & $3.54 \times 10^{-3}$ & $3.66 \times 10^{-3}$ \\
\hline & c & $1 / \mathrm{yr}$ & O & 0.771 & 1.688 & 0.553 & 2.430 & 1.360 \\
\hline & $\varepsilon_{\mathrm{BIO}}$ & - & 0 & 0.051 & 0.083 & 0.037 & 0.001 & 0.043 \\
\hline & $d$ & $1 / \mathrm{yr}$ & $\mathrm{O}$ & 0.805 & 1.706 & 0.490 & 0.003 & 0.751 \\
\hline & $\mathrm{R}^{2}$ & - & $C$ & 0.992 & 0.981 & 0.981 & 0.851 & 0.974 \\
\hline
\end{tabular}

Note: $\mathrm{M}=$ measured parameter, $\mathrm{C}=$ computed parameter, $\mathrm{F}=$ fixed parameter, $\mathrm{O}=$ optimized parameter, $\mathrm{WL}=$ waste layer, Ave. = arithmetic average of the four waste layer parameters and $\mathrm{R}^{2}$ for each model is estimated for Prediction consideration. 
Table 8. Summary of model parameters and coefficients of determination for the full composite waste settlement models based on DTBE (continued).

\begin{tabular}{|c|c|c|c|c|c|c|c|c|}
\hline Model & Parameter & Unit & Type & WL1 & WL2 & WL3 & WL4 & Ave. \\
\hline \multirow{17}{*}{ Babu } & $\mathrm{H}_{0}$ & $\mathrm{~m}$ & $\mathrm{M}$ & 1.80 & 2.23 & 2.00 & 1.76 & - \\
\hline & $\sigma_{\mathrm{o}}$ & $\mathrm{kPa}$ & $M$ & 8.3 & 7.0 & 6.6 & 6.5 & - \\
\hline & $\Delta \sigma$ & $\mathrm{kPa}$ & $\mathrm{M}$ & 68.2 & 52.9 & 39.2 & 19.5 & - \\
\hline & $\gamma_{d}$ & $\mathrm{kN} / \mathrm{m}^{3}$ & $M$ & 6.89 & 4.98 & 5.03 & 5.27 & - \\
\hline & $\mathrm{G}_{\mathrm{s}}$ & - & $\mathrm{F}$ & 1.34 & 1.34 & 1.34 & 1.34 & - \\
\hline & $\phi$ & $\circ$ & $\mathrm{F}$ & 37.0 & 37.0 & 37.0 & 37.0 & - \\
\hline & $t_{B}$ & $\mathrm{yr}$ & $\mathrm{F}$ & 0.449 & 0.449 & 0.449 & 0.449 & - \\
\hline & $\lambda$ & - & 0 & 0.182 & 0.305 & 0.281 & 0.252 & 0.255 \\
\hline & $\kappa$ & - & 0 & 0.018 & 0.031 & 0.028 & 0.025 & 0.025 \\
\hline & $\eta$ & - & $\mathrm{O}$ & 1.22 & 1.09 & 1.23 & 2.09 & 1.41 \\
\hline & $\mathrm{b}$ & $1 / \mathrm{kPa}$ & 0 & $8.53 \times 10^{-4}$ & $1.10 \times 10^{-3}$ & $7.28 \times 10^{-3}$ & $3.54 \times 10^{-3}$ & $3.19 \times 10^{-3}$ \\
\hline & $\mathrm{c}$ & $1 / \mathrm{yr}$ & 0 & 5.04 & 5.67 & 0.554 & 2.43 & 3.43 \\
\hline & $\varepsilon_{\mathrm{BIO}}$ & - & $\mathrm{O}$ & 0.156 & 0.121 & 0.038 & 0.001 & 0.079 \\
\hline & $k$ & $1 / \mathrm{yr}$ & $\mathrm{O}$ & 0.764 & 1.70 & 0.507 & 0.004 & 0.744 \\
\hline & $M$ & - & $\mathrm{C}$ & 1.51 & 1.51 & 1.51 & 1.51 & - \\
\hline & $\mathrm{e}$ & - & $\mathrm{C}$ & 0.908 & 1.640 & 1.615 & 1.494 & - \\
\hline & $\mathrm{R}^{2}$ & - & $\mathrm{C}$ & 0.991 & 0.980 & 0.981 & 0.851 & 0.947 \\
\hline \multirow{4}{*}{$\begin{array}{l}\text { Chen- } \\
2010\end{array}$} & $\mathrm{C}_{\mathrm{c}}{ }^{\prime}$ & - & $\mathrm{O}$ & 0.224 & 0.246 & 0.240 & 0.304 & 0.254 \\
\hline & $\varepsilon_{\mathrm{MB}}$ & - & O & 0.219 & 0.197 & 0.338 & 0.069 & 0.206 \\
\hline & $c_{t}$ & $1 / \mathrm{yr}$ & 0 & 0.659 & 1.19 & 0.506 & 2.43 & 1.196 \\
\hline & $\mathrm{R}^{2}$ & - & $C$ & 0.991 & 0.968 & 0.981 & 0.851 & 0.979 \\
\hline
\end{tabular}

Note: $\mathrm{M}=$ measured parameter, $\mathrm{C}=$ computed parameter, $\mathrm{F}=$ fixed parameter, $\mathrm{O}=$ optimized parameter, $W L=$ waste layer, Ave. = arithmetic average of the four waste layer parameters and $R^{2}$ of this column for each model is estimated for prediction. 
Table 8. Summary of model parameters and coefficients of determination for the full composite waste settlement models based on DTBE data (continued).

\begin{tabular}{|c|c|c|c|c|c|c|c|c|}
\hline Model & Parameter & Unit & Type & WL1 & WL2 & WL3 & WL4 & Ave. $^{a}$ \\
\hline \multirow{23}{*}{$\begin{array}{l}\text { Chen- } \\
2012\end{array}$} & $\mathrm{H}_{0}$ & $\mathrm{~m}$ & $M$ & 1.80 & 2.23 & 2.00 & 1.76 & - \\
\hline & $\mathrm{V}_{0}$ & $\mathrm{~m}^{3}$ & $M$ & 8.42 & 10.44 & 9.35 & 8.24 & - \\
\hline & $\mathrm{W}$ & $\%$ & $M$ & 33 & 26.4 & 31.7 & 40.8 & - \\
\hline & $T$ & ${ }^{\circ} \mathrm{K}$ & $M$ & 311.25 & 311.25 & 311.25 & 311.25 & - \\
\hline & $g$ & $\mathrm{~m} / \mathrm{sec}^{2}$ & $\mathrm{M}$ & 9.81 & 9.81 & 9.81 & 9.81 & \\
\hline & $\rho_{w}$ & $\mathrm{~kg} / \mathrm{m}^{3}$ & $M$ & 1000 & 1000 & 1000 & 1000 & - \\
\hline & $\rho$ & $\mathrm{kg} / \mathrm{m}^{3}$ & $M$ & 959.6 & 877 & 864.8 & 841.6 & - \\
\hline & $\mathrm{G}_{\mathrm{s}}$ & - & $\mathrm{F}$ & 1.34 & 1.34 & 1.34 & 1.34 & - \\
\hline & $\rho_{\mathrm{s}}$ & $\mathrm{kg} / \mathrm{m}^{3}$ & $\mathrm{~F}$ & 1340 & 1340 & 1340 & 1340 & - \\
\hline & $\omega_{\mathrm{i}}$ & $\mathrm{kg} / \mathrm{mole}$ & $\mathrm{F}$ & 0.0288 & 0.0288 & 0.0288 & 0.0288 & - \\
\hline & $\omega_{b}$ & $\mathrm{~kg} / \mathrm{mole}$ & $\mathrm{F}$ & 0.03 & 0.03 & 0.03 & 0.03 & - \\
\hline & $\mathrm{k}$ & $1 / \mathrm{yr}$ & 0 & 0.551 & 0.936 & 0.436 & 0.088 & 0.503 \\
\hline & $\mathrm{k}_{\mathrm{a}}$ & $\mathrm{m} / \mathrm{yr}$ & 0 & 5.48 & 7.35 & 4.64 & 6.81 & 6.07 \\
\hline & $m_{3}$ & $\mathrm{~m}^{2} / \mathrm{N}$ & 0 & $-3.13 \times 10^{-4}$ & $-4.61 \times 10^{-4}$ & $-6.75 \times 10^{-4}$ & $-1.72 \times 10^{-4}$ & $-4.05 \times 10^{-4}$ \\
\hline & $\mathrm{u}_{0}$ & $\mathrm{~N} / \mathrm{m}^{2}$ & 0 & 927 & 740 & 605 & 1276 & 887 \\
\hline & $r_{b}$ & $\%$ & $\mathrm{C}$ & 21.6 & 18.7 & 24.5 & 35.1 & - \\
\hline & $\mathrm{n}$ & - & $C$ & 0.476 & 0.621 & 0.618 & 0.599 & - \\
\hline & $S$ & $\%$ & C & 0.487 & 0.216 & 0.263 & 0.366 & - \\
\hline & $\mathrm{R}$ & $\begin{array}{c}\mathrm{Nm} / \\
(\mathrm{mole} \cdot \mathrm{K})\end{array}$ & C & 8.314 & 8.314 & 8.314 & 8.314 & - \\
\hline & $\mathrm{M}_{\text {so }}^{*}$ & $\mathrm{~kg}$ & $C$ & 7865 & 6695 & 6311 & 6235 & - \\
\hline & $M_{\text {so }}$ & $\mathrm{kg}$ & $C$ & 1699 & 1252 & 1546 & 2188 & - \\
\hline & $\mathrm{V}_{\mathrm{G}}$ & $\mathrm{m}^{3}$ & C & 3.99 & 6.47 & 5.76 & 4.92 & - \\
\hline & $\mathrm{R}^{2}$ & - & C & 0.991 & 0.966 & 0.981 & 0.662 & 0.911 \\
\hline
\end{tabular}

Note: $\mathrm{M}=$ measured parameter, $\mathrm{C}=$ computed parameter, $\mathrm{F}=$ fixed parameter, $\mathrm{O}=$ optimized parameter, $\mathrm{WL}=$ waste layer, Ave. = arithmetic average of the four waste layer parameters and $R^{2}$ of this column for each model is estimated for prediction. 
Table 9. Summary of model parameters and coefficients of determination for the timedependent waste settlement models based on DTBE data.

\begin{tabular}{|c|c|c|c|c|c|c|c|c|}
\hline Model & Parameter & Unit & Type & WL1 & WL2 & WL3 & WL4 & Ave. \\
\hline \multirow{14}{*}{ Machado } & $\mathrm{H}_{\mathrm{EOI}}$ & $\mathrm{m}$ & $M$ & 1.41 & 1.69 & 1.60 & 1.45 & - \\
\hline & $\gamma_{d}$ & $\mathrm{kN} / \mathrm{m}^{3}$ & $\mathrm{M}$ & 6.89 & 4.98 & 5.03 & 5.27 & - \\
\hline & $\rho_{s}^{*}$ & $\mathrm{Mg} / \mathrm{m}^{3}$ & $M$ & 1.34 & 1.34 & 1.34 & 1.34 & - \\
\hline & $\rho_{p}^{*}$ & $\mathrm{Mg} / \mathrm{m}^{3}$ & $\mathrm{M}$ & 1.4 & 1.4 & 1.4 & 1.4 & - \\
\hline & $w$ & - & $\mathrm{M}$ & 0.330 & 0.264 & 0.317 & 0.408 & - \\
\hline & $\mathrm{L}_{0}$ & $\mathrm{~m}^{3} / \mathrm{Mg}$ & $\mathrm{F}$ & 51.4 & 51.4 & 51.4 & 51.4 & - \\
\hline & $t_{M}$ & $\mathrm{yr}$ & $\mathrm{F}$ & 0.041 & 0.041 & 0.0411 & 0.041 & - \\
\hline & $C_{m}$ & $\mathrm{~m}^{3} / \mathrm{Mg}$ & $\mathrm{F}$ & 450 & 450 & 450 & 450 & - \\
\hline & $\mathrm{C}_{\mathrm{c}}^{\prime}$ & - & $\mathrm{O}$ & 0.229 & 0.260 & 0.246 & 0.312 & 0.262 \\
\hline & $\mathrm{C}_{\alpha M^{\prime}}$ & - & 0 & 0.017 & 0.017 & 0.033 & 0.047 & 0.028 \\
\hline & $\alpha^{*}$ & - & $\mathrm{O}$ & 24.7 & 40.2 & 57.9 & 1.400 & 31.1 \\
\hline & $\mathrm{k}$ & $1 / \mathrm{yr}$ & $\mathrm{O}$ & 1.00 & 1.64 & 0.889 & 0.000 & 0.883 \\
\hline & $\mathrm{e}_{\mathrm{o}}$ & - & $\mathrm{C}$ & 0.908 & 1.64 & 1.62 & 1.49 & - \\
\hline & $\mathrm{R}^{2}$ & - & $C$ & 0.993 & 0.976 & 0.983 & 0.839 & 0.999 \\
\hline \multirow{6}{*}{ Gourc } & $t_{B}$ & $\mathrm{yr}$ & $\mathrm{F}$ & 0.449 & 0.449 & 0.449 & 0.449 & - \\
\hline & $\mathrm{C}_{\mathrm{c}}{ }^{\prime}$ & - & $\mathrm{O}$ & 0.227 & 0.272 & 0.234 & 0.312 & 0.261 \\
\hline & $\mathrm{C}_{\alpha M^{\prime}}$ & - & 0 & 0.056 & 0.049 & 0.081 & 0.047 & 0.058 \\
\hline & $\mathrm{k}$ & $1 / \mathrm{yr}$ & 0 & 0.836 & 2.03 & 0.529 & 0.019 & 0.853 \\
\hline & $\varepsilon_{\mathrm{BIO}}$ & - & 0 & 0.149 & 0.131 & 0.248 & 0.000 & 0.132 \\
\hline & $\mathrm{R}^{2}$ & - & $C$ & 0.991 & 0.977 & 0.980 & 0.856 & 0.999 \\
\hline
\end{tabular}

Note: $\mathrm{M}=$ measured parameter, $\mathrm{C}=$ computed parameter, $\mathrm{F}=$ fixed parameter, $\mathrm{O}=$ optimized parameter, $W L=$ waste layer, Ave. = arithmetic average of the four waste layer parameters and $R^{2}$ of this column for each model is estimated for prediction. 


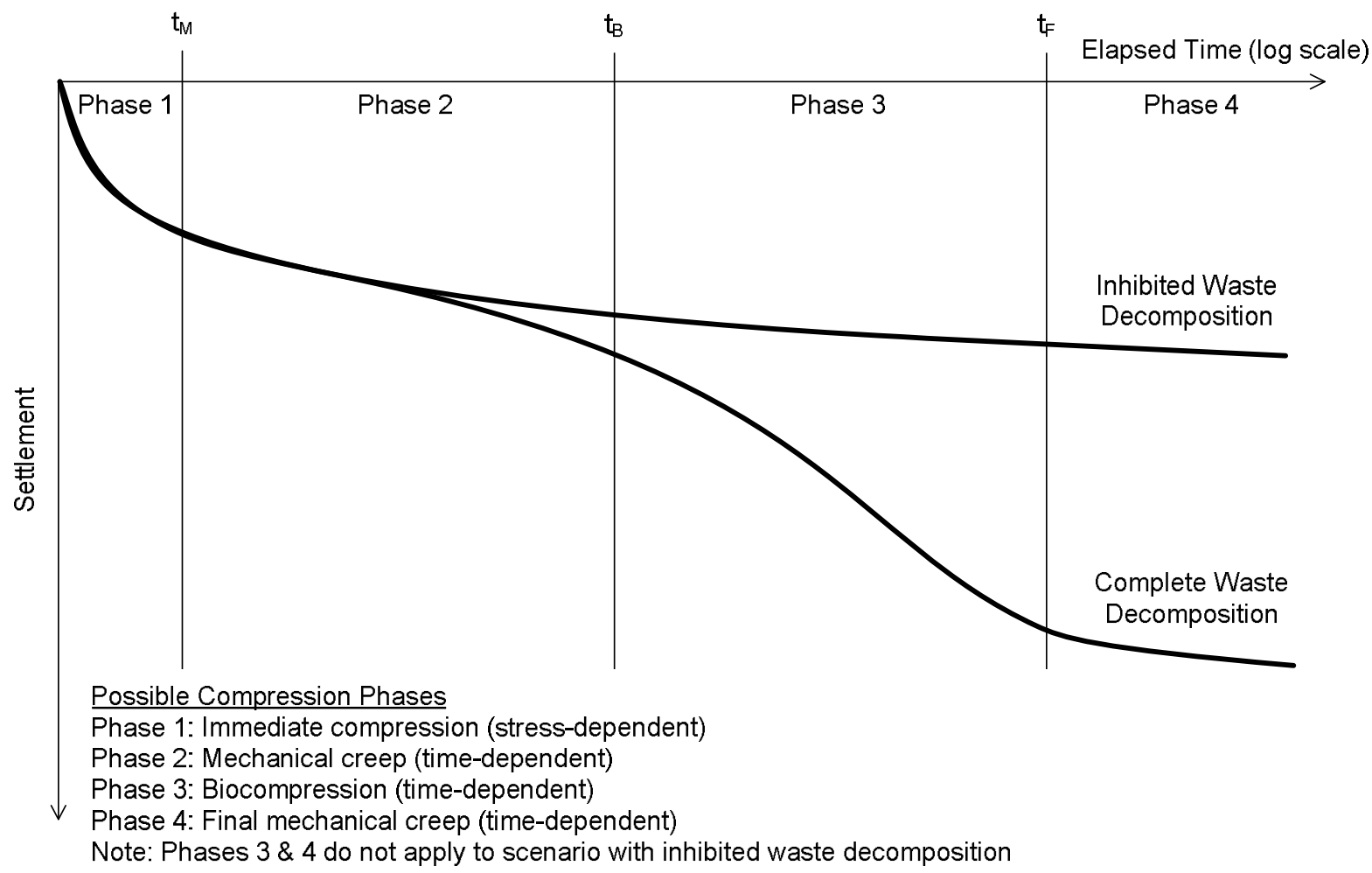

Fig. 1. Conceptual models of municipal solid waste settlement with (i) inhibited and (ii) complete waste decomposition. Temporal definitions: $t_{M}=$ elapsed time for end-of-immediate compression, $\mathrm{t}_{\mathrm{B}}=$ elapsed time for onset of biocompression, and $\mathrm{t}_{\mathrm{F}}=$ elapsed time for completion of waste biodegradation and transition to final mechanical creep. 

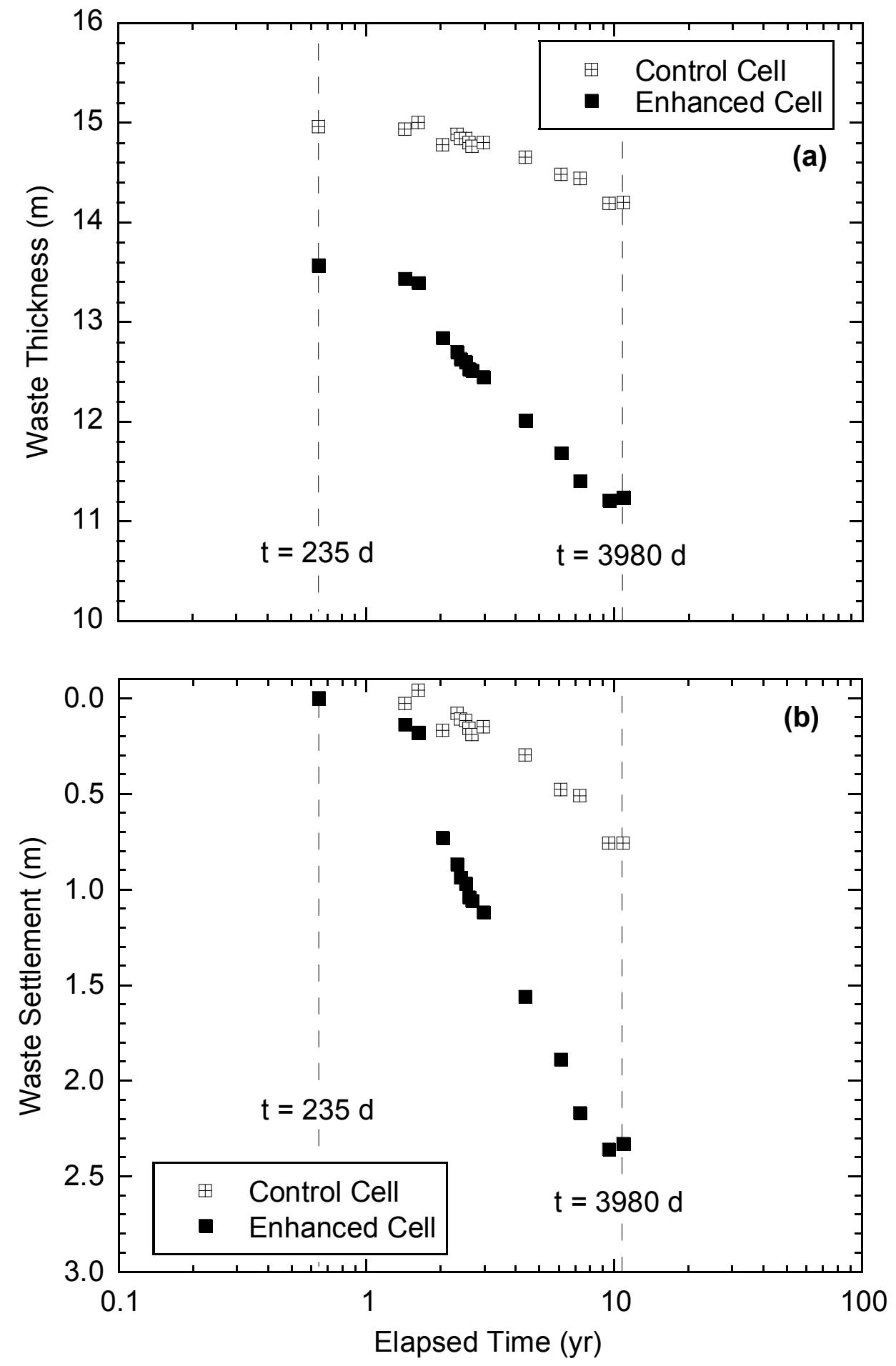

Fig. 2. Temporal trends of waste thickness and settlement for the Yolo Enhanced and Control cells. 
(a)

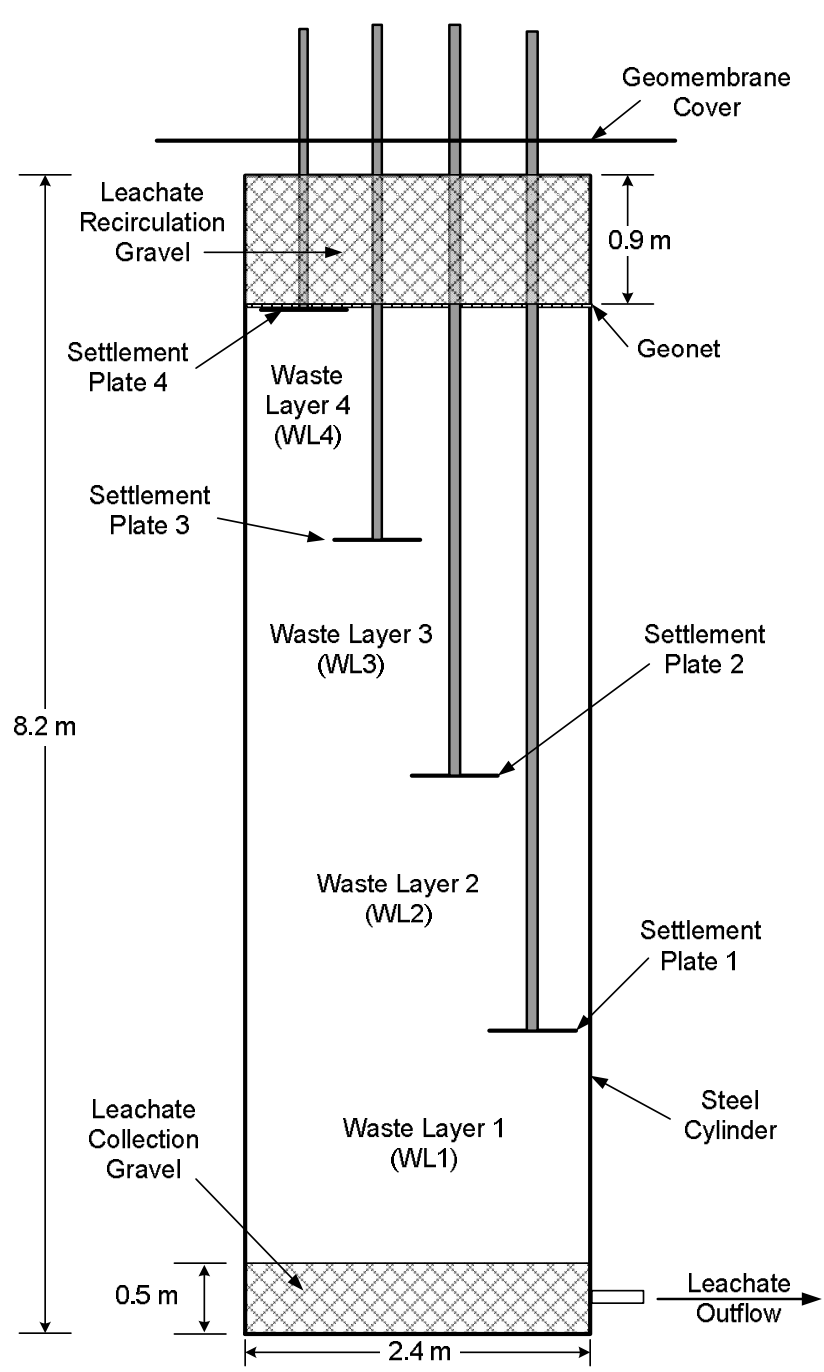

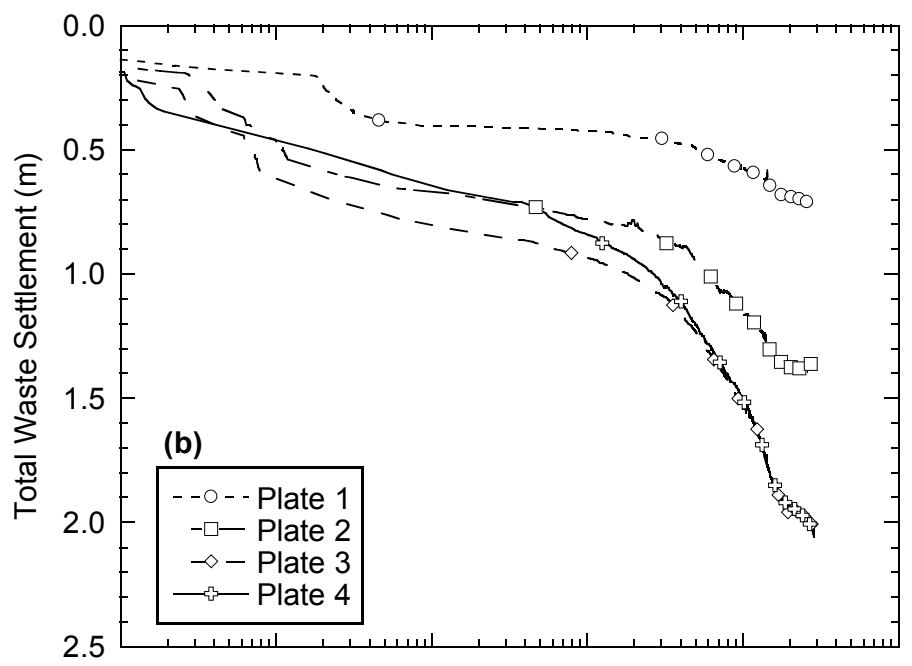

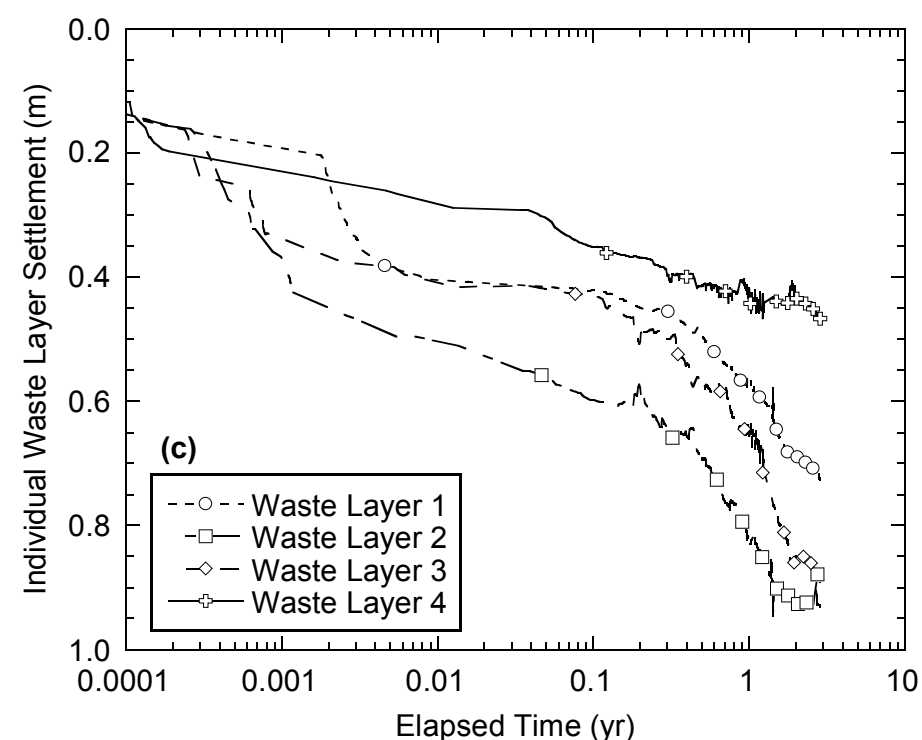

Fig. 3. (a) Schematic of the Deer Track Bioreactor Experiment and temporal relationships of (b) total waste settlement measured for each settlement plate and (c) settlement of individual waste layers. 


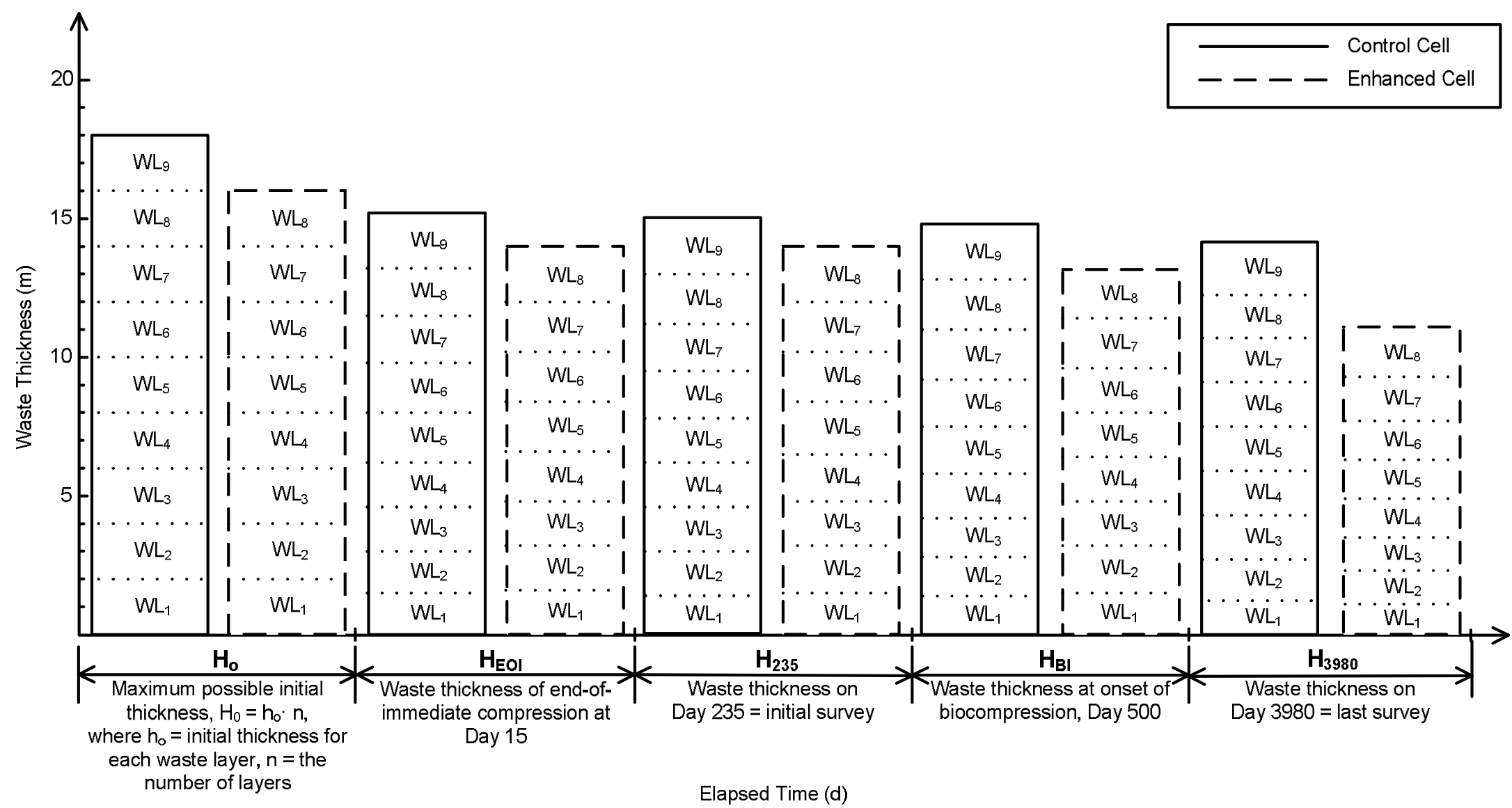

Fig. 4. Total waste thicknesses and individual waste layer thickness for the Enhanced and Control cells at Yolo. Dashed lines indicate individual waste layer thicknesses; these thicknesses for $\mathrm{H}_{235}, \mathrm{H}_{500}$, and $\mathrm{H}_{3980}$ are averages from the model simulations. The waste thickness corresponding to $\mathrm{H}_{0}$ and $\mathrm{H}_{\mathrm{EO}}$ are based on assumptions outlined in the multi-layer settlement analysis. Waste thicknesses corresponding to $\mathrm{H}_{235}$ and $\mathrm{H}_{3980}$ are based on final cover elevation surveys conducted at Yolo. 


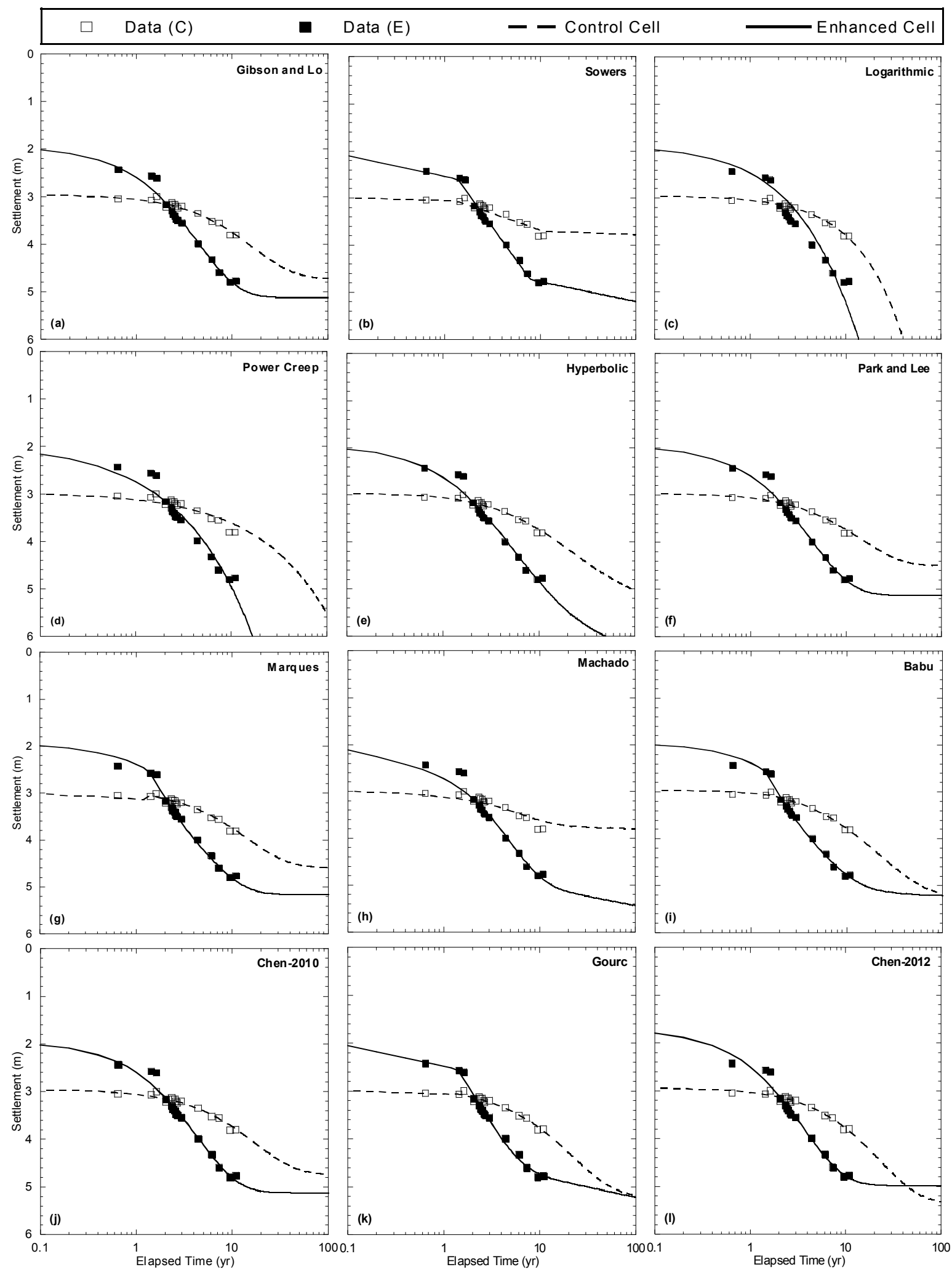

Fig. 5. Measured settlement and settlement model fits for the Yolo Control and Enhanced cells. 

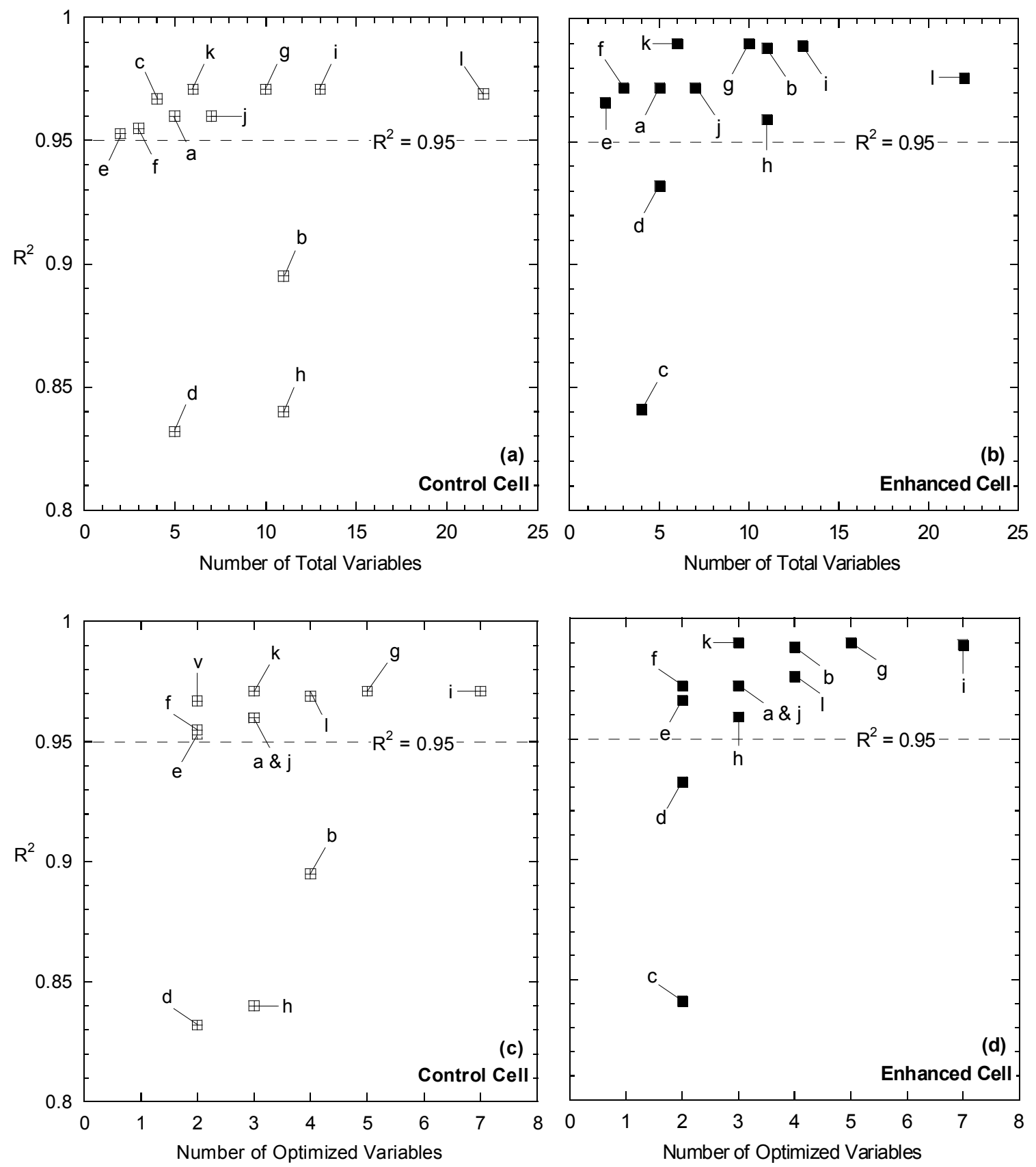

Fig. 6. Coefficient of determination versus total number of model parameters for (a) Control cell and (b) Enhanced cell and versus number of optimized model parameters for (c) Control cell and (d) Enhanced cell. Settlement model references: $a=$ Gibson and Lo; $b=$ Sowers; $c=$ Logarithm; $d=$ Power Creep; $e=$ Hyperbolic; $f=$ Park and Lee; $g=$ Marques; $h=$ Machado; i = Babu; j = Chen-2010; k = Gourc; and I = Chen-2012. 

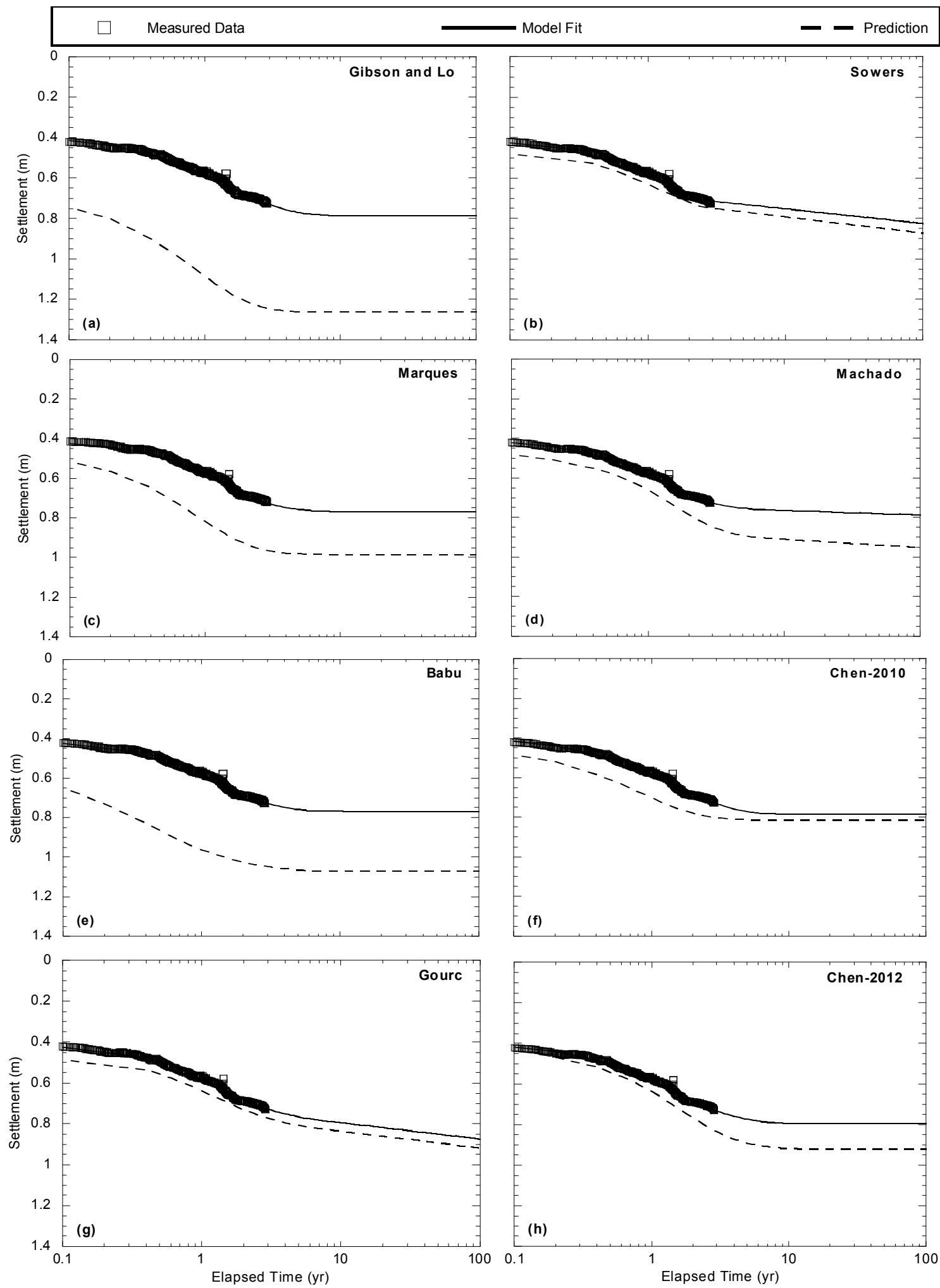

Fig. 7. Cumulative settlement versus time for Waste Layer 1 (WL1) of the DTBE data as well as fitted and predicted settlement. Prediction was generated via applying average, optimizted model parameters from the four waste layers in the DTBE to WL1 conditions. 

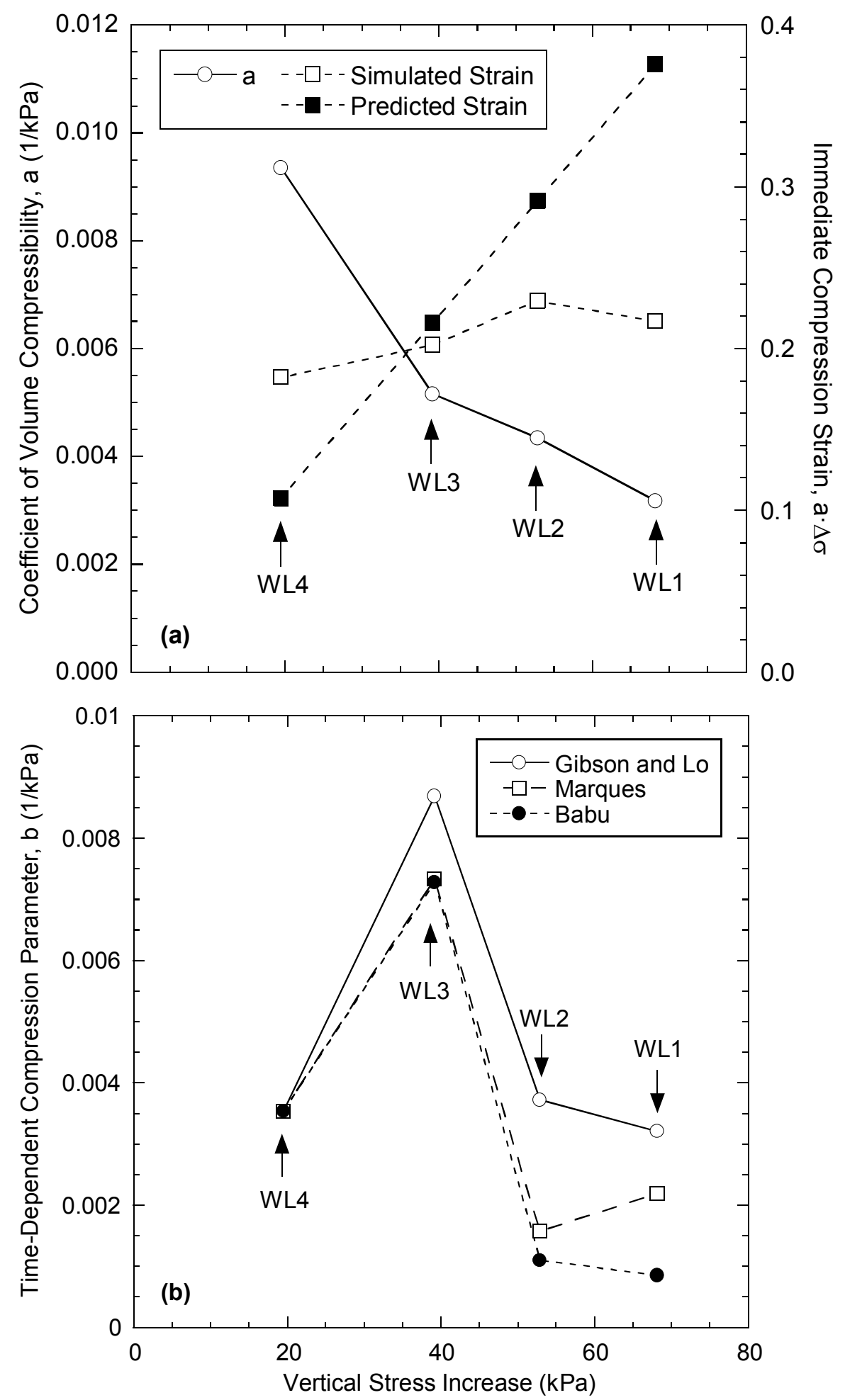

Fig. 8. Relationships between (a) coefficient of volume compressibility and immediate compression strain for Gibson and Lo model and (b) time-dependent compression parameter versus vertical stress increase for the Gibson and Lo, Marques, and Babu models. Model parameters are from the four waste layer settlement simulations conducted for the Deer Track Bioreactor Experiment. 


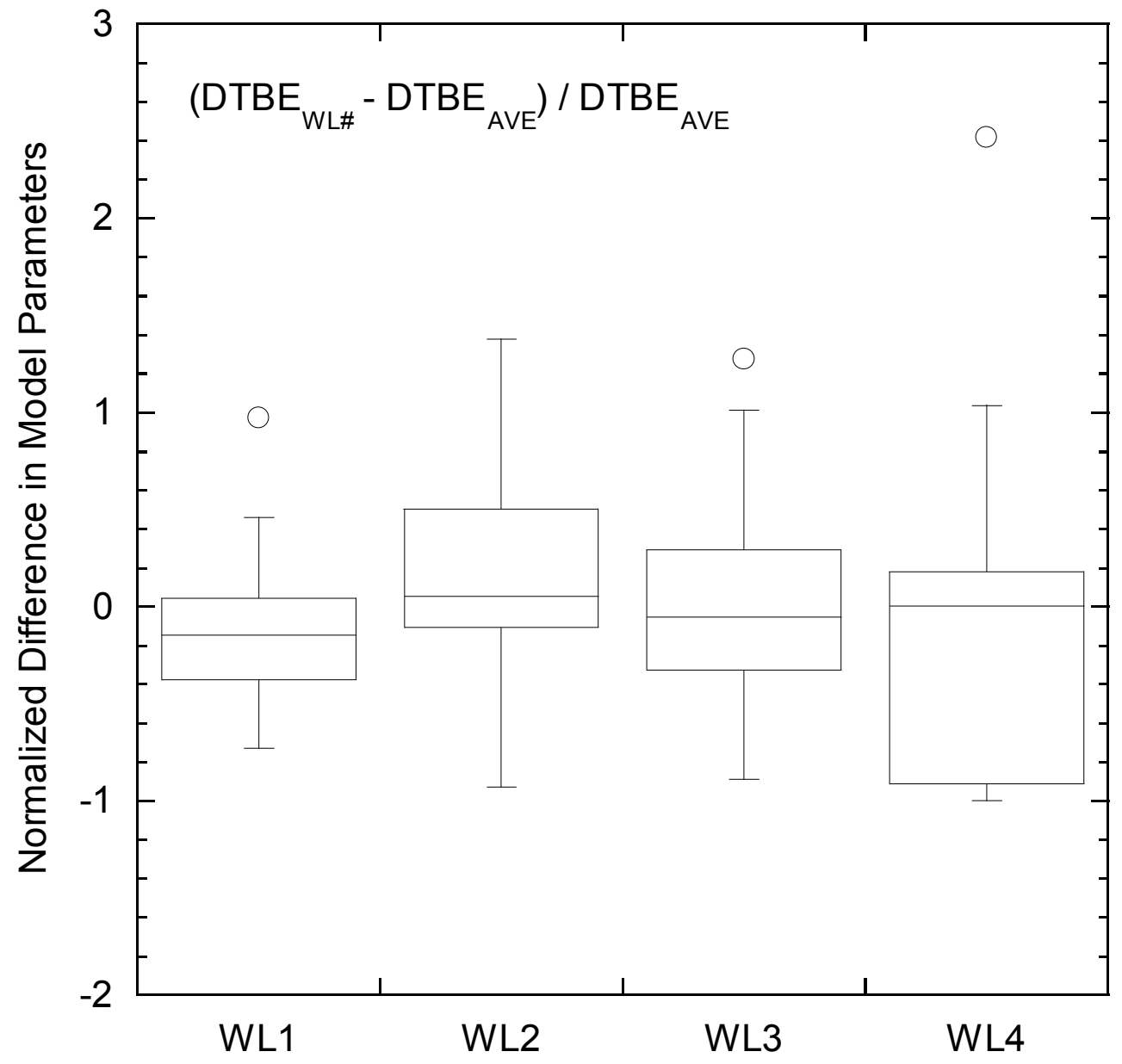

Fig. 9. Box plot of the normalized difference between settlement model parameters for a given waste layer (WL) in the Deer Track Bioreactor Experiment (DTBE) and the arithmetic average of model parameters for all four WLs in the DTBE. The box represents the middle $50 \%$ of the data; the central line in the box represents the median; the outer boundaries represent the interquartile range (i.e., $25^{\text {th }}$ and $75^{\text {th }}$ percentile); and the upper and lower whiskers extending from the box constitute $5^{\text {th }}$ and $95^{\text {th }}$ percentile of the data. 

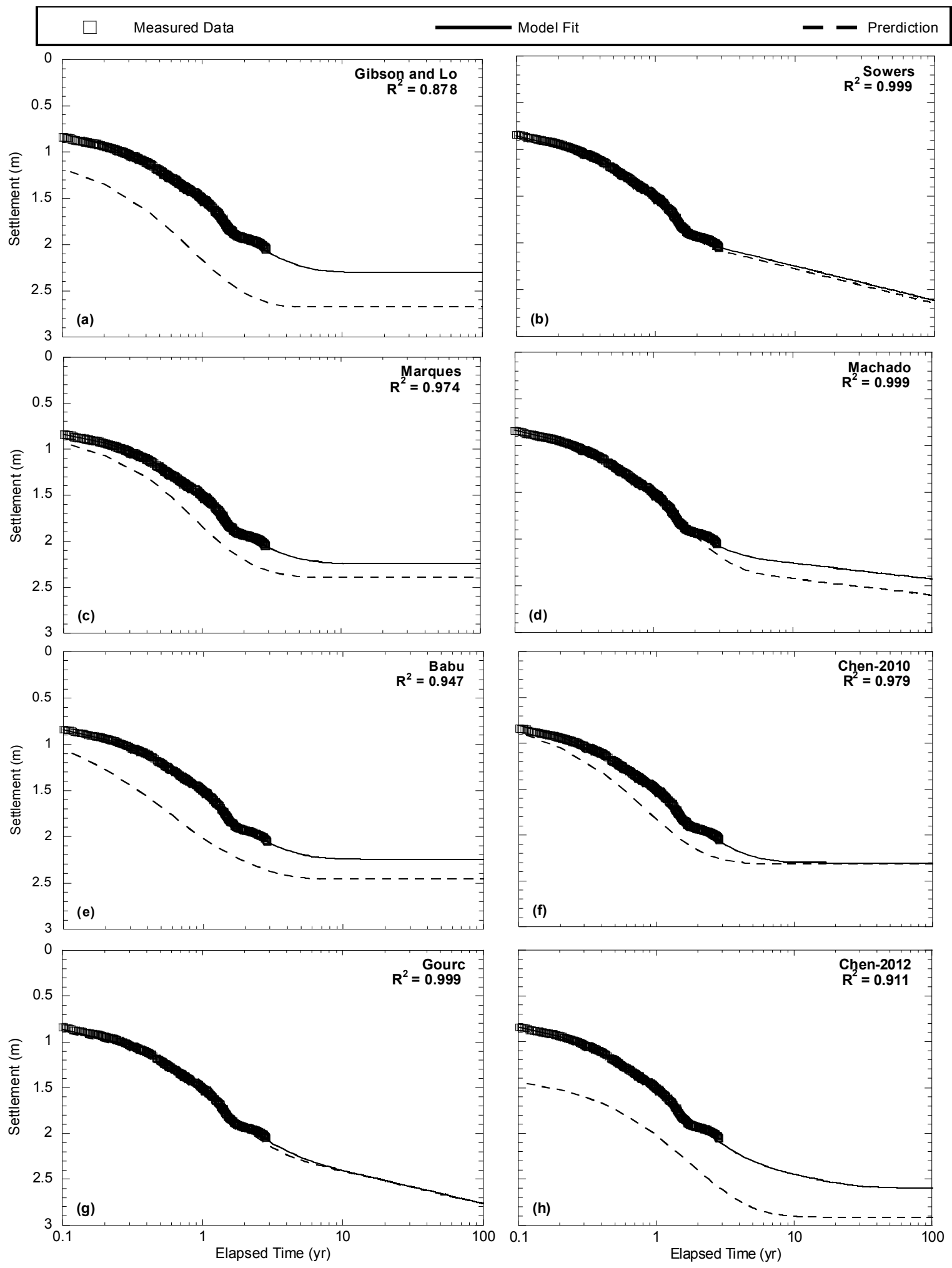

Fig. 10. Measured settlement at the top of the DTBE (Plate 4), model fit based on use of layerspecific optimized model parameters, and prediction based on use of average, optimized model parameters for each waste layer. 


\section{REFERENCES}

Abichou, T., Barlaz, M. A., Green, R., and Hater, G. (2013). The Outer Loop bioreactor: a case study of settlement monitoring and solids decomposition, Waste Management, 33(10), 2035-2047.

Babu Sivakumar, G. L., Reddy, K. R., Chouskey S. K., (2010). Constitutive model for municipal solid waste incorporating mechanical creep and biodegradation-induced compression, Waste Management, 30(1), 11-22.

Bareither, C. A., Benson, C. H., Barlaz, M. A., Edil, T. B., Tolaymat, T. M. (2010). Performance of North American bioreactor landfills: I. leachate hydrology and waste settlement, J. Environ. Eng., 136(8), 824-838.

Bareither, C. A., Benson, C. H., Edil, T. B., and Barlaz, M. A. (2012a). Abiotic and biotic compression of municipal solid waste, J. Geotech. Geoenviron. Eng., 138(8), 887-888.

Bareither, C. A., Breitmeyer, R. J., Benson, C. H., Barlaz, M. A., and Edil, T. B. (2012b). Deer Track Bioreactor Experiment: a field-scale evaluation of municipal solid waste bioreactor performance, J. Geotech. Geoenviron. Eng., 138(6), 658-670.

Bareither, C. A., Benson, C. H., and Edil, T. B. (2012c). Compression behavior of municipal solid waste: immediate compression, J. Geotech. Geoenviron. Eng., 138(9), 1047-1062.

Bareither, C. A., Benson, C. H., and Edil, T. B. (2012d). "Effects of Waste Composition and Decomposition on the Shear Strength of Municipal Solid Waste." J. Geotech. Geoenviron. Eng., 138(10), 1161-1174.

Bareither, C. A., Benson, C. H., and Edil, T. B. (2013). Compression of Municipal Solid Waste in Bioreactor Landfills: Mechanical Creep and Biocompression, J. Geotech. Geoenviron. Eng., 139(7), 1007-1021.

Beaven, R. P. and Powrie, W. (1996). Determination of the hydrogeological and geotechnical properties of refuse in relation to sustainable landfilling, Proc. 19th Int. Madison Waste Conf., University of Wisconsin-Madison, Madison, WI, USA, 435-454.

Berthouex, P. M., and Brown, L. C. (2002). Statistics for Environmental Engineers, 2nd Ed., Lewis Publishers, Boca Raton, FL.

Bjarngard, A., and Edgers, L. (1990). Settlement of municipal solid waste landfills, Proc. 13th Int. Madison Waste Conf., University of Wisconsin-Madison, Madison, WI, USA, 192-205.

Chen, Y., Ke, H., Fredlund, D. G., Zhan, L., and Xie, Y. (2010). Seconday compression of Municipal solid wastes and a compression model for predicting settlement of municipal solid waste landfills, J. Geotech. Geoenviron. Eng., 136(5), 706-717.

Chen, K. S., Chen, R. H, and Liu, C-N. (2012). Modeling municipal solid waste landfill settlement, J. Environ. Eng. Sci., 66(8), 2301-2309.

Edil, T. B., Ranguette V. J., and Wuellner W. W. (1990). Settlement of municipal refuse, Geotechnics of Waste Fills-Theory and Practice, STP 1070, A. O. Landva and G. D. Knowles, eds., ASTM, West Conshohocken, PA, USA, 225-239. 
El-Fadel, M., Khoury, R. (2000). Modeling settlement in MSW landfills: A critical review, Crit. Rev. Environ. Sci. Technol., 30(3), 327-361.

Gibson, R. E., and Lo, K. Y. (1961). A theory of soils exhibiting secondary compression. Acta Polytech. Scand., C10, 1-15.

Gourc, J. P., Staub, M. J., Conte M. (2010). Decoupling MSW settlements into mechanical and biochemical processes - modeling and validation on large-scale setups, Waste Management, 30(8-9), 1556-1568.

Hossain, M.S., Gabr, M.A., and Barlaz, M.A. (2003). Relationship of compressibility parameters to municipal solid waste decomposition. Geotech. Geoenviron. Eng., 129(12), 1151-1158

Hossain, M. S., and Gabr, M. A. (2005). Prediction of municipal solid waste landfill settlement with leachate recirculation. Proc. Geo-Frontiers, GSP No. 142, Waste Containment and Remediation, ASCE, 1-14.

Ivanova, L. K., Richards, D. J., and Smallman, D. J. (2008). The long-term settlement of landfill waste, Water Resour. Manage., 161(WR3), 121-133.

Kavazanjian, E., Jr., Matasovic, N., and Bachus, R. C. (1999). Large diameter static and cyclic laboratory testing of municipal solid waste. Proc., 7th Int. Waste Management and Landfill Symp., CISA, Environmental Sanitary Engineering Centre, Cagliari, Italy, 437-444.

Ling, H, I., Leshchinsky, D., Mohri, Y., and Kawabata, T. (1998). Estimation of municipal solid waste landfill settlement, J. Geotech. Geoenviron. Eng., 124(1), 21-28.

Liu, C., Chen, R., and Chen K. (2006). Unsaturated consolidation theory for the prediction of long-term municipal solid waste landfill settlement. Waste Management, 24, 80-91.

Machado, S. L., Carvalho, M. F. and Vilar, O. M. (2002). Constitutive model for municipal solid waste, J. Geotech. Geoenviron. Eng., 128(11), 940-951.

Machado, S. L. and Carvalho, M. (2009). Constitutive model for municipal solid waste incorporating mechanical creep and biodegradation-induced compression. Waste Management, 30(1), 11-22.

Marques, A. C. M., Filz, G. M., and Vilar, O. M. (2003). Composite compressibility model for municipal solid waste, J. Geotech. Geoenviron. Eng., 129(4), 372-378.

McDougall, J. R. and Pyrah, I. C. (2004). Phase relations for decomposable soils, Geotechnique, 54(7), 487-493.

Mehta, R., Barlaz, M. A., Yazdani, R., Augenstein, D., Bryars, M., and Sinderson, L. (2002). Refuse decomposition in the presence and absence of leachate recirculation, J. Environ. Eng., 128(3), 228-236.

Olivier, F., Gourc, J.-P., 2007. Hydro-mechanical behavior of municipal solid waste subject to leachate recirculation in a large-scale compression reactor cell. Waste Manag. 27, 44-58. 
Park, H. I. and Lee, S. R. (1997). Long-term settlement behavior of landfills with refuse decomposition, J. Res. Manage. \& Tech., 24(4), 159-165.

Park, H. I. and Lee, S. R. (2002). Long-term settlement behavior of MSW landfills with various fill ages, Waste Manage. Res., 20(3), 259-268.

Park, H. I., Park, B., Lee, S. R., and Hwang, D. (2007). Parameter evaluation and performance comparison of MSW settlement Prediction models in various landfill types, J. Environ. Eng., 133(1), 64-72.

Sharma, H. D., and De, A. (2007). Municipal solid waste landfill settlement: Post closure perspectives. J. Geotech. Geoenviron. Eng., 133(6), 619-629.

Siddiqui, A., Powrie, W., and Richards, D. (2013). Settlement Characteristics of Mechanically Biologically Treated Wastes. J. Geotech. Geoenviron. Eng., 139(10), 1676-1689.

Sowers, G, F. (1973). Settlement of waste disposal fills. Proc. 8th Int. Conf. on Soil Mech, and Found, Engr., Balkema, Rotterdam, 22, 207-210.

Staley, B. F., and Barlaz, M. A. (2009). Composition of municipal solid waste in the U.S. and implications for carbon sequestration and methane yield, J. Environ. Eng., 135(10), 901-909.

Tan, T. -S., Inoue, T., and Lee, S. -L (1991). Hyperbolic method for consolidation analysis, J. Geotech. Eng., ASCE, 117(11), 1723-1737.

Vilar, O. M. and Carvalho, M. F. (2004). Mechanical properties of municipal solid waste, Journal of Testing and Evaluation, 32(6), 438-449.

Wood, D. M. (1990). Soil Behavior and Critical State Soil Mechanics, Cambridge University Press, United Kingdom.

Yazdani, R, Kieffer, J., Sananikone, K., and Augenstein, D. (2006). Full scale bioreactor landfill for carbon sequestration and greenhouse emission control, final report, Award No. DEFC26-01NT41152, U.S. Department of Energy, Washington, DC.

Yen, B. C. and Scanlon, B. (1975). Sanitary landfill settlement rates, J. Geotech. Eng. Div., ASCE, 101(5), 475-487. 


\section{APPENDIX A: SUPPLEMENTAL DISCUSSION OF MUNICIPAL SOLID WASTE SETTLEMENT MODELS}

Machado et al. (2009)

The change in biocompression strain $\left(d \varepsilon_{b}\right)$ as related to methane generation and mass loss in MSW is expressed as follows:

$$
d \varepsilon_{b}=-\left(\frac{\rho_{s}^{*}}{\rho_{p}^{*}}\right) \cdot\left(\frac{1}{1+e_{o}}\right) \cdot(1+\alpha) \cdot \frac{\partial M_{s o}}{\partial t} \cdot \frac{1}{M_{s o}^{*}} d t
$$

where $\rho_{s}^{*}$ is initial density of MSW solid material, $\rho_{p}^{*}$ is initial density of MSW paste, $e_{o}$ is initial void ratio, $M_{s o}$ is MSW solid mass, $M_{s o}^{*}$ is initial MSW solid mass, and a is a decompositioninduced void change parameter similar to the parameter described in McDougall and Pyrah (2004). The initial void ratio $\left(e_{0}\right)$ can be computed as

$$
e_{o}=\frac{G_{s} \gamma_{w}}{\gamma_{d}}-1
$$

where $G_{s}$ is specific gravity, $\gamma_{w}$ is unit weight of water, and $\gamma_{d}$ is dry unit weight of the waste. Determining $e_{o}$ is dependent on $G_{s}$, which changes as waste decomposes (Bareither et al. 2012c).

The parameter $\alpha$ can be computed as

$$
\alpha=\alpha_{o}+\frac{\alpha^{*}\left(-\Delta M_{s o}\right)}{M_{s o}^{*}}
$$

where $\alpha_{0}$ is the initial $\alpha$ before biodegradation, $\alpha^{*}$ is the rate of increase in $\alpha$ with biodegradation, and $-\Delta \mathrm{M}_{\mathrm{so}} / \mathrm{M}_{\text {so }}^{*}$ represents the cumulative mass loss in MSW due to biodegradation. According to McDougall and Pyrah (2004), a should range between -1 and $e_{0}$, and Machado et al. (2009) suggest setting $\alpha_{o}$ equal to zero for simplicity. The rate of mass loss with respect to time in Eq. A3 can be related to methane generation as

$$
-\frac{\partial M_{s o}}{\partial t} \frac{1}{M_{s o}^{*}}=\frac{L_{o} k(1+w) e^{-k t}}{C_{m}}
$$


where $L_{0}$ is methane generation potential $\left(\mathrm{m}^{3}-\mathrm{CH}_{4} / \mathrm{Mg}\right.$-dry-MSW), $w$ is water content of MSW, $k$ is the first-order decay coefficient, and $C_{m}$ is the organic matter methane yield. Machado et al. (2009) recommend setting $C_{m}=450 \mathrm{~m}^{3}-\mathrm{CH}_{4} / \mathrm{Mg}$-dry-MSW if insufficient information is available to determine $C_{m}$.

Substituting Eqs. A2 through A4 into Eq. A1 yields Eq. A5.

$$
d \varepsilon_{b}=\left\{\frac{\rho_{s}^{*} L_{o}(1+w) k}{\rho^{*}{ }_{p} C_{m}\left(1+e_{o}\right)} e^{-k t}\left[1+\alpha \frac{L_{o}(1+w)\left(1-e^{-k t}\right)}{C_{m}}\right]\right\} d t
$$

Time-dependent settlement due to biocompression is computed by integrating Eq. A5 with respect to time to yield Eq. A6.

$$
S_{B}(t)=H_{E O I} \frac{\rho_{s}^{*} L_{o}(1+w)}{\rho_{p}^{*} C_{m}\left(1+e_{o}\right)}\left\{\left[1+\frac{\alpha^{*} L_{o}(1+w)}{C_{m}}\right]\left(1-e^{-k t}\right)-\frac{\alpha^{*} L_{o}(1+w)}{2 C_{m}}\left(1-e^{-2 k t}\right)\right\}
$$

Total time-dependent settlement is computed by coupling $S_{M C}$ from Eq. 6 and $S_{B}$ from Eq. A6 to yield Eq. A7.

$$
S_{T D}(t)=H_{E O I} C_{\alpha M}^{\prime} \log \left(\frac{t}{t_{M}}\right)+H_{E O I} \frac{\rho_{s}^{*} L_{o}(1+w)}{\rho_{p}^{*} C_{m}\left(1+e_{o}\right)}\left\{\left[1+\frac{\alpha^{*} L_{o}(1+w)}{C_{m}}\right]\left(1-e^{-k t}\right)-\frac{\alpha^{*} L_{o}(1+w)}{2 C_{m}}\left(1-e^{-2 k t}\right)\right\}
$$

\section{Babu et al. (2010)}

Total MSW compression strain in Babu et al. (2010) is represented via a change in MSW volume, and accounts for stress history, mechanical creep, and biodegradation. The stressdependent immediate strain consists of plastic and elastic strains. The plastic strain $\left(d \varepsilon_{v}^{p}\right)$ can be computed as follows:

$$
d \varepsilon_{v}^{p}=\left(\frac{\lambda-\kappa}{1+e}\right)\left[\frac{d p}{p}+\frac{2 \eta d \eta}{M^{2}+\eta^{2}}\right]
$$

where $\lambda$ is compression index, $\kappa$ is recompression or swelling index (approximately 10 to $20 \%$ of $\lambda), p$ is mean normal stress, $M$ is the slope of critical state line in $p-q$ plane [equal to $6 \cdot \sin \phi /(2-$ 
$\sin \phi)$, where $\phi$ is the internal friction angle of MSW], and $\eta$ is the stress ratio of $q / p$. The initial void ratio can be computed using Eq. A2. Elastic strain $\left(d \varepsilon_{v}^{e}\right)$ is computed via Eq. A9.

$$
d \varepsilon_{v}^{e}=\frac{\kappa}{1+e} \frac{d p}{p}
$$

Time-dependent strain due to mechanical creep $\left(d \varepsilon_{v}^{c}\right)$ is computed as:

$$
d \varepsilon_{v}^{c}=c b \Delta \sigma_{v} e^{-c t} d t
$$

where $c$ is the mechanical creep rate constant, and $b$ is the coefficient of mechanical creep. Integrating Eq. A10 will yield the time-dependent deformation model presented in Gibson and Lo (1961). Time-dependent strain due to biocompression $\left(d \varepsilon_{v}^{b}\right)$ is estimated via the Park and Lee (1997) biodegradation model as follows:

$$
d \varepsilon_{v}^{b}= \begin{cases}0 & \left(\text { if } t<t_{B}\right) \\ k \varepsilon_{B / O} e^{-k\left(t-t_{b}\right)} d t & \left(\text { if } t>t_{B}\right)\end{cases}
$$

where $t_{B}$ is elapsed time for the onset of biocompression, $\varepsilon_{\mathrm{BIO}}$ is total amount of strain due to biodegradation of MSW, and $k$ is the first-order decay coefficient. Total volumetric strain $\left(d \varepsilon_{v}\right)$ can be computed by combining strain due to immediate compression (Eqs. A8 and A9), mechanical creep (Eq. A10), and biocompression (Eq. A11) to yield Eqs. A12 and A13.

$$
\begin{gathered}
d \varepsilon_{v}=d \varepsilon_{v}^{e}+d \varepsilon_{v}^{p}+d \varepsilon_{v}^{c}+d \varepsilon_{v}^{b} \\
d \varepsilon_{v}=\frac{\lambda}{1+e} \frac{d p}{p_{o}}+\left(\frac{\lambda-\kappa}{1+e}\right) \frac{2 \eta d \eta}{M^{2}+\eta^{2}}+b \Delta \sigma_{v} e^{-c t} d t+\varepsilon_{B I O} e^{-k\left(t-t_{B}\right)} d t
\end{gathered}
$$

The parameter $p_{o}$ is pre-consolidation stress corresponding to $\sigma_{o}$, assuming an overconsolidation ratio of 1.0 (i.e., normally consolidated). The frictional constant is taken as 1.51 with $\phi=37^{\circ}$ in accordance with Bareither et al. (2012d) for both datasets.

Based on an assumption of one-dimensional compression and, integrating Eq. A13 with respect to $p, \eta$, and $t$ yields an expression for the total MSW settlement (Eq. A14). 


$$
S_{T}(t)=H_{\circ}\left[\frac{\lambda}{1+e} \ln \left(\frac{p}{p_{o}}\right)+\left(\frac{\lambda-\kappa}{1+e}\right) \ln \left(\frac{M^{2}+\eta^{2}}{M^{2}}\right)+b \Delta \sigma_{v}\left(1-e^{-c t}\right)+\varepsilon_{B I O}\left(1-e^{-k\left(t-t_{B}\right)}\right)\right]
$$

According to Wood (1990) and Machado et al. (2002), $p$ and $p_{o}$ can be estimated by $\sigma$ and $\Delta \sigma_{v}$, where $p=\left(\sigma_{v o}+2 \Delta \sigma_{v}\right) / 3$. The final MSW settlement model implemented in this study is Eq. A15:

$$
S_{T}(t)=H_{o}\left[\frac{\lambda}{1+e} \ln \left(\frac{\sigma_{v o}+2 \Delta \sigma_{v}}{3 \sigma_{v o}}\right)+\left(\frac{\lambda-\kappa}{1+e}\right) \ln \left(\frac{M^{2}+\eta^{2}}{M^{2}}\right)+b \Delta \sigma\left(1-e^{-c t}\right)+\varepsilon_{B I O}\left(1-e^{-k\left(t-t_{B}\right)}\right)\right]
$$

which couples a critical soil mechanics approach for immediate compression, rheological model for mechanical creep (Gibson and Lo 1961), and first-order decay model for biodegradationinduced compression (Park and Lee 1997).

\section{Chen et al. (2012)}

Time-dependent volumetric strain due to a change in pore air pressure as a function of depth $(z)$ and time $(t)$ is originally presented in Liu et al. (2006) for MSW as follows:

$$
\frac{\partial u_{a}}{\partial t}=A \frac{\partial^{2} u_{a}}{\partial z^{2}}+B e^{-k t}
$$

where the first term on the right-hand-side corresponds to spatial diffusion due to gas pressure and the second term on the right-hand-side corresponds to temporal variation due to biocompression. The coefficient $A$ represents air phase compression and the coefficient $B$ represents a constant related to biodegradation of organic matter. Both coefficients are formulated to express excess gas pressure within MSW as follows:

$$
A=\frac{-V_{o} k_{a} R T}{\varpi_{i}\left(m_{3} V_{o} \overline{u_{a}}+V_{G}\right) g}, \quad B=\frac{\left(\varpi_{i}-\varpi_{b}\right) M_{s o} k R T}{\varpi_{i} \varpi_{b}\left(m_{3} V_{o} \overline{u_{a}}+V_{G}\right)}
$$

where $V_{o}$ is initial total MSW volume, $k$ is the first-order decay coefficient, $k_{a}$ is gas conductivity, $R$ is the universal gas constant $(8.314 \mathrm{~N}-\mathrm{m} / \mathrm{mol}-\mathrm{K}), T$ is absolute temperature, $g$ is acceleration of gravity, $m_{3}$ is the coefficient gas volume change (value will be negative due to the upward net flux of gas assumed to be positive), and $\bar{u}_{a}$ is absolute pore gas pressure. The factors related to 
molecular mass are $\varpi_{\mathrm{i}}$ for initial air in the void volume and $\varpi_{\mathrm{b}}$ for biogas generated from organic waste biodegradation. Both molecular mass parameters $\left(\varpi_{i}\right.$ and $\left.\varpi_{b}\right)$ can be obtained on the assumption that biogas generation due to waste decomposition is comprised solely of methane and carbon dioxide in equal volumetric fractions. According to Liu et al. (2006), the volume of gas in MSW $\left(V_{G}\right)$ can be related to $V_{0}$, porosity $(n)$, and saturation $(S)$ (i.e., $V_{G}=V_{o} \times n \times(1-S)$ ). The porosity and saturation in a given landfill mass can be computed as

$$
n=1-\frac{\rho}{\rho_{s}(1+w)}, \quad B=\frac{\rho_{s} w}{\rho_{w}} \times \frac{1-n}{n}
$$

where $\rho$ is bulk MSW density and $\rho_{\mathrm{s}}$ is density of the MSW solids. Chen et al. (2012) proposed a general condition for MSW via assuming $\varpi_{i}=0.0288 \mathrm{~kg} / \mathrm{mole}$ and $\varpi_{b}=0.03 \mathrm{~kg} / \mathrm{mole}$. The initial organic fraction of solid MSW mass $\left(M_{s o}\right)$ is equal to the product of total solid mass of dry $\operatorname{MSW}\left(M_{s o}^{*}\right)$ and mass ratio of biodegradable organic waste $\left(r_{b}=M_{s o} / M_{s o}^{*}\right)$. The absolute pore gas pressure is computed as the product of initial gas pressure $\left(u_{i}\right)$ and gas pressure due to biodegradation $\left(u_{b}\right)$ as

$$
\bar{u}_{a}=u_{i}+u_{b}=\frac{\rho_{i}}{\varpi_{i}} R T+\frac{M_{s o} R T}{V_{G} \varpi_{b}}\left(1-e^{-k t}\right)
$$

where $\rho_{\mathrm{i}}$ is initial density of the waste.

Chen et al. (2012) develop an analytical solution with the following initial and boundary conditions: (i) initial spatial gas pressure $u_{a(z, 0)}$ is assumed equal to $u_{0}$ regardless of MSW depth (i.e., $\left.u_{a(z, 0)}=u_{0}\right)$, (ii) excess pore gas pressure at the landfill boundary is equal to zero (i.e., $\left.u_{a(0, t)}=0\right)$, and (iii) the gas pressure gradient at an impervious boundary (e.g., liner system) is zero based on a no gas flow assumption (i.e., $d u_{a} /\left.d z\right|_{\left(H_{0}, t\right)}=0$ ). The following analytical solution is presented with respect to landfill depth $(z)$ and elapsed time $(t)$ : 


$$
u_{a}(z, t)=\sum_{n=0}^{\infty}\left[\frac{4 u_{o}}{(2 n+1) \pi} e^{-\lambda_{n} t}+\frac{4 B}{(2 n+1) \pi\left(\lambda_{n}-k\right)}\left(e^{-k t}-e^{-\lambda_{n} t}\right)\right] \sin (p z)
$$

where $\lambda_{n}=A p^{2}$ and $p=\frac{(2 n+1) \pi}{2 H_{0}}$. This equation can be used to express the change in discharged gas volume as a function of compression due to mechanical creep $\left(e^{-\lambda_{n} t}\right)$ and biodegradation $\left(e^{-k t}\right)$. The change in gas volume of the waste $\left(\Delta V_{G(z, t)}\right)$ with $t$ and $z$ is

$$
\Delta V_{G}(z, t)=m_{3} \Delta u_{a(z, t)} V_{o}+\frac{M_{s o}}{\rho_{s}}\left(1-e^{-k t}\right)
$$

where change in gas pressure at a specific location and time is equal to $u_{a(z, t)}-u_{0}$. Volumetric strain in terms of $t$ and $z$ can be estimated by combining spatial diffusion due to gas pressure and temporal variation due to biocompression as shown in Eq. A22.

$$
\varepsilon_{T}(z, t)=\frac{\Delta V_{G(z, t)}}{V_{0}}=m_{3}\left[u_{a}(z, t)-u_{0}\right]+\frac{M_{s o}}{\rho_{s} V_{0}}\left(1-e^{-k t}\right)
$$

Strain is assumed to primarily occur due to vertical deformation, and total strain along a specified profile of MSW at a given time $t$ can be computed as the following summation:

$$
\varepsilon_{T}(t)=\sum_{z=1}^{N} \varepsilon(z, t)
$$

where $N$ is the number of MSW layers. Thus, total time-dependent MSW settlement can be calculated by multiplying $\varepsilon_{\mathrm{T}}$ and $H_{0}$ as shown in Eq. A23.

$$
S_{T}(t)=H_{0} \sum_{z=1}^{H_{0}} m_{3}\left\{\left[\sum_{n=1}^{\infty}\left(\frac{4 u_{o}}{(2 n+1) \pi} e^{-\lambda_{n} t}+\frac{4 B}{(2 n+1) \pi\left(\lambda_{n}-k\right)}\left(e^{-k t}-e^{-\lambda_{n} t}\right)\right) \sin (p z)-u_{o}\right]+\frac{M_{s o}}{\rho_{s} V_{o}}\left(1-e^{-k t}\right)\right\}
$$

Chen et al. (2012) suggest using four parameters $\left(k, k_{a}, m_{3}\right.$, and $\left.u_{0}\right)$ as optimized parameters since they are unknown and settlement data may be needed to fit the model. 


\section{APPENDIX B: FILLING SEQUENCE AND WASTE LAYER CALCULATIONS FOR THE DEER TRACK BIOREACTOR EXPERIMENT}

A summary of waste characteristics for the initial-filling and end-of-filling scenarios for the DTBE is included in Table 3. These waste characteristics are presented with respect to the waste layers between adjacent settlement plates. Schematics of the filling sequence in the DTBE and equations developed to determine waste layer characteristics for both the initial-filling and end-of-filling scenarios are in Fig. B1. A gravel layer (GL) initially was placed at the bottom of the DTBE and subsequently four waste layers (WL) were placed during filling operations. The initial-filling scenario is representative of WLs as placed with no subsequent waste placed on top. The end-of-filling scenario is representative of final waste placement (i.e., all four WLs in place) and prior to placement of the top GL.

The schematics included for the after-filling scenario are included to show how stress increases $(\Delta \sigma)$ were determined for each of the individual waste layers. Settlement simulations completed for individual waste layers were based on initial-filling characteristics (Table 3) and measured settlement was due to placement of all subsequent WLs and the top GL. Settlement predictions for the composite waste profile (Fig. 10) were generated via considering WL characteristics for the end-of-filling scenario (Plate 4 Filling Sequence in Fig. B1) prior to placement of the top GL. Thus, settlement measured for Plate 4 that was used in Fig. 10 was due to placement of the top GL and self-weight of the waste. 


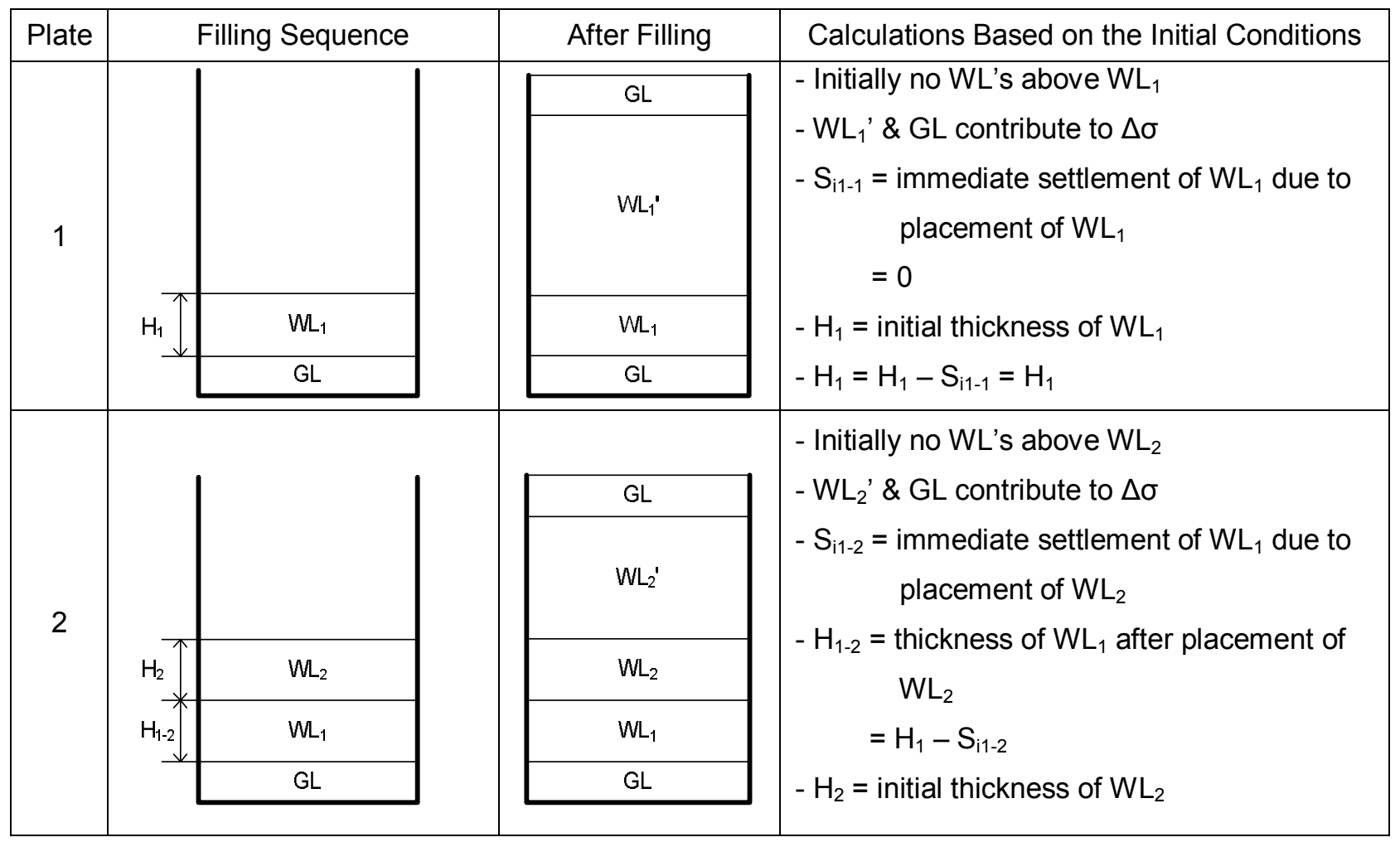

Fig. 11. Schematic of filling sequence in the DTBE and corresponding equations used to compute waste characteristics for the initial-filling and end-of-filling scenarios. 


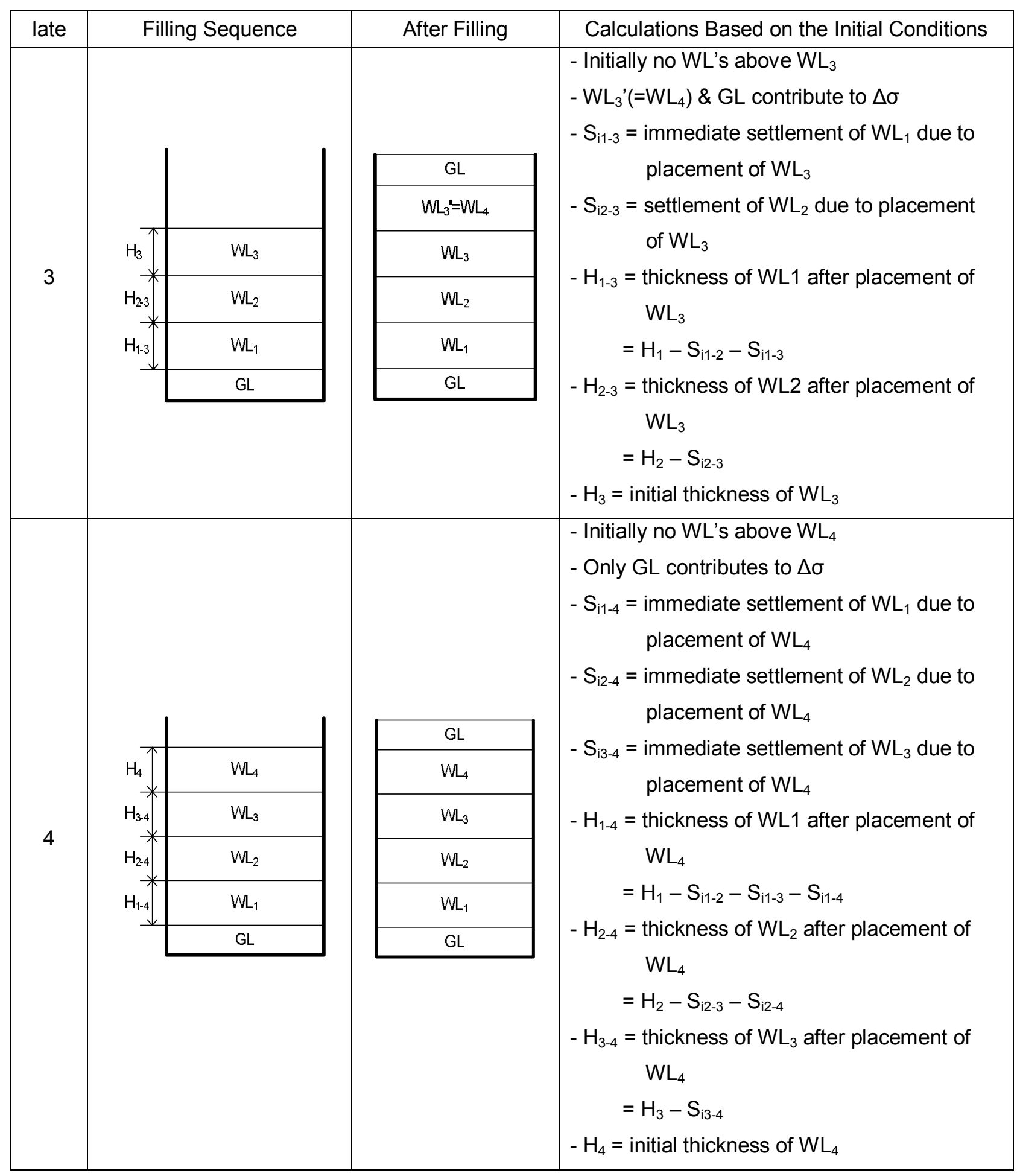

Fig. 11. Schematic of filling sequence in the DTBE and corresponding equations used to compute waste characteristics for the initial-filling and end-of-filling scenarios (continued). 
APPENDIX C: SUPPLEMENTAL WASTE SETTLEMENT PLOTS FOR WASTE LAYERS 2, 3, AND 4 IN THE DEER TRACK BIOREACTOR EXPERIMENT
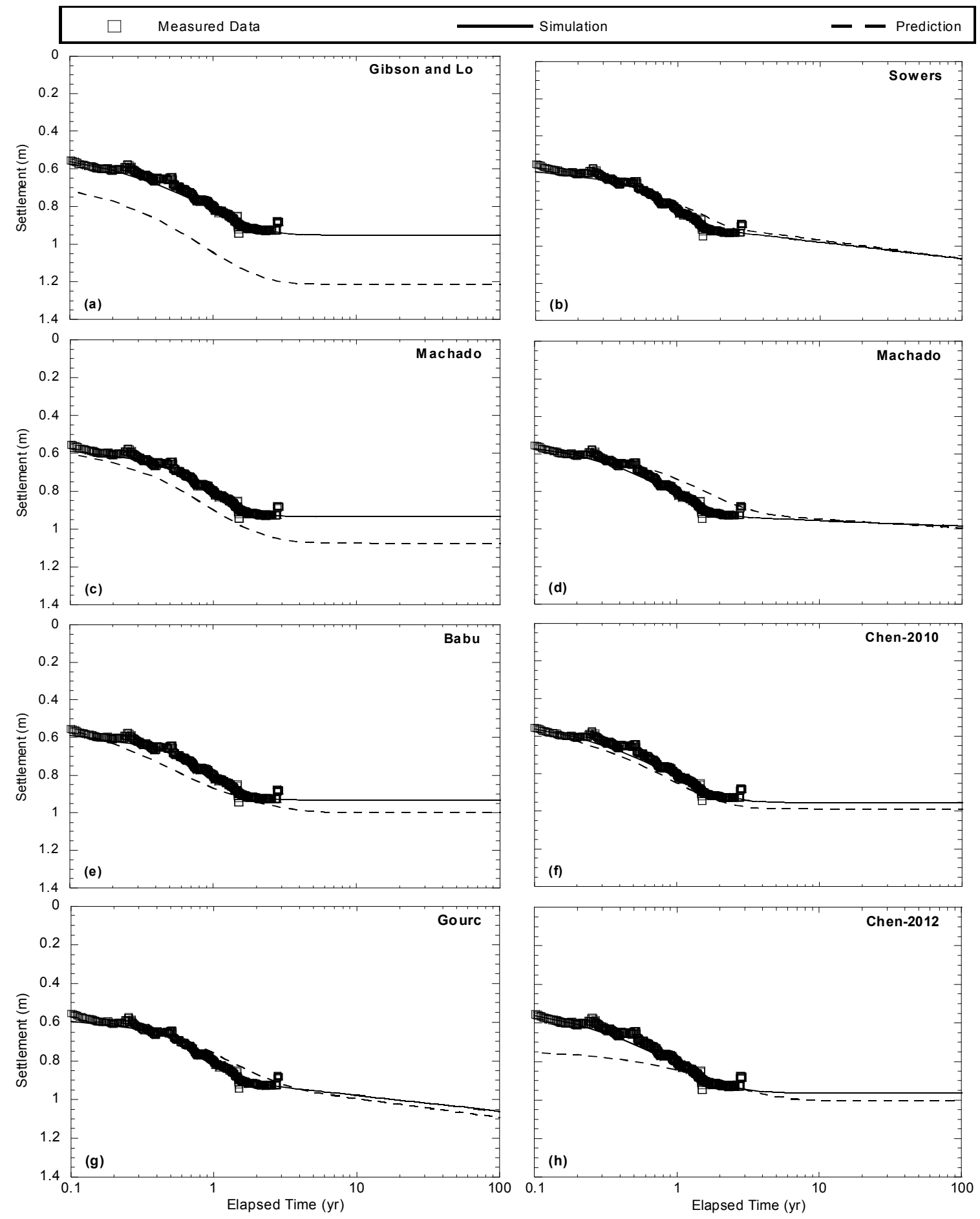

Fig. 12. Measured, simulated, and predicted settlement for Waste Layer 2 in the DTBE. Predicted settlement is based on the arithmetic average of optimized model parameters from the four simulated waste layers. 

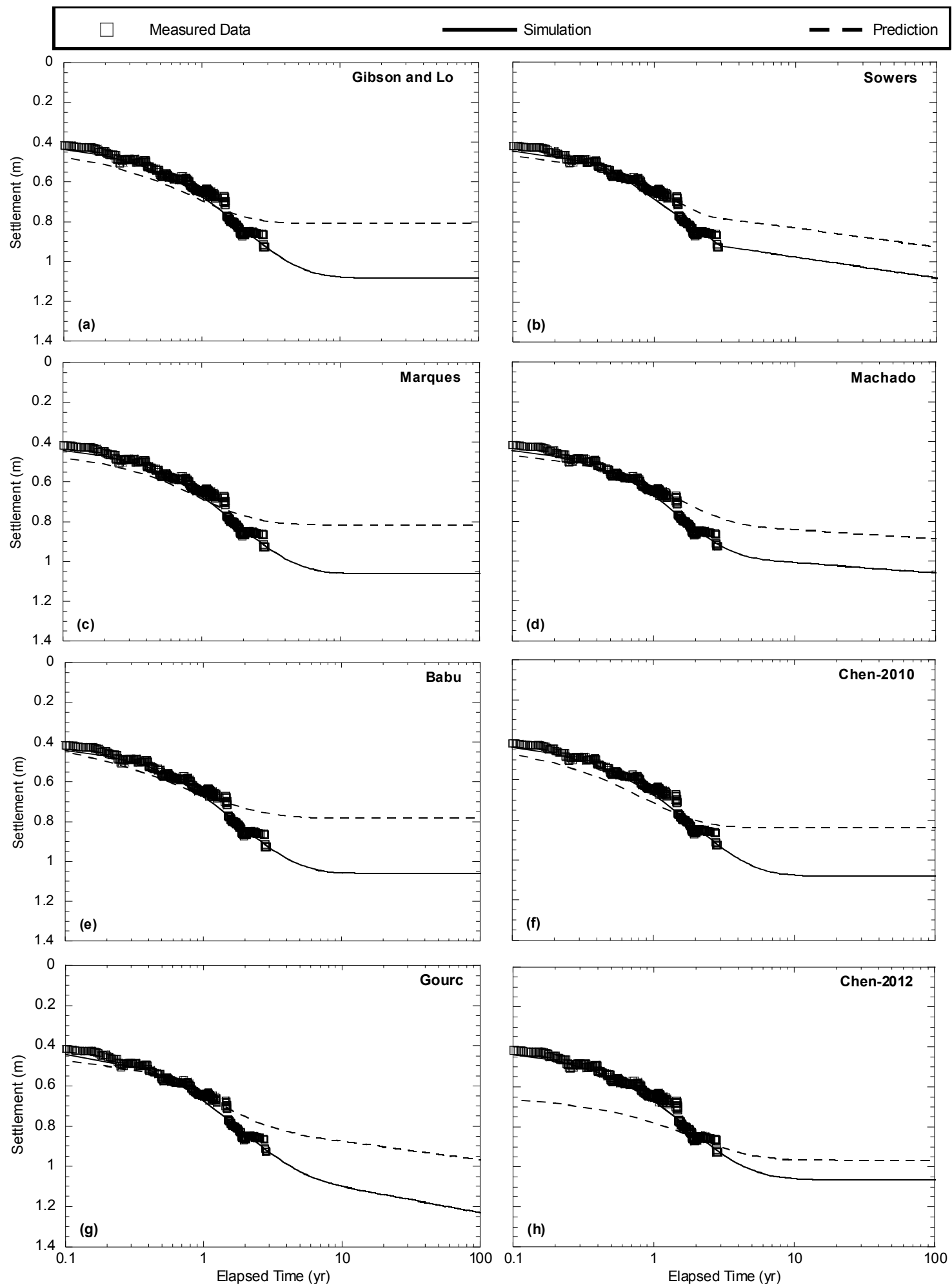

Fig. 13. Measured, simulated, and predicted settlement for Waste Layer 3 in the DTBE. Predicted settlement is based on the arithmetic average of optimized model parameters from the four simulated waste layers. 

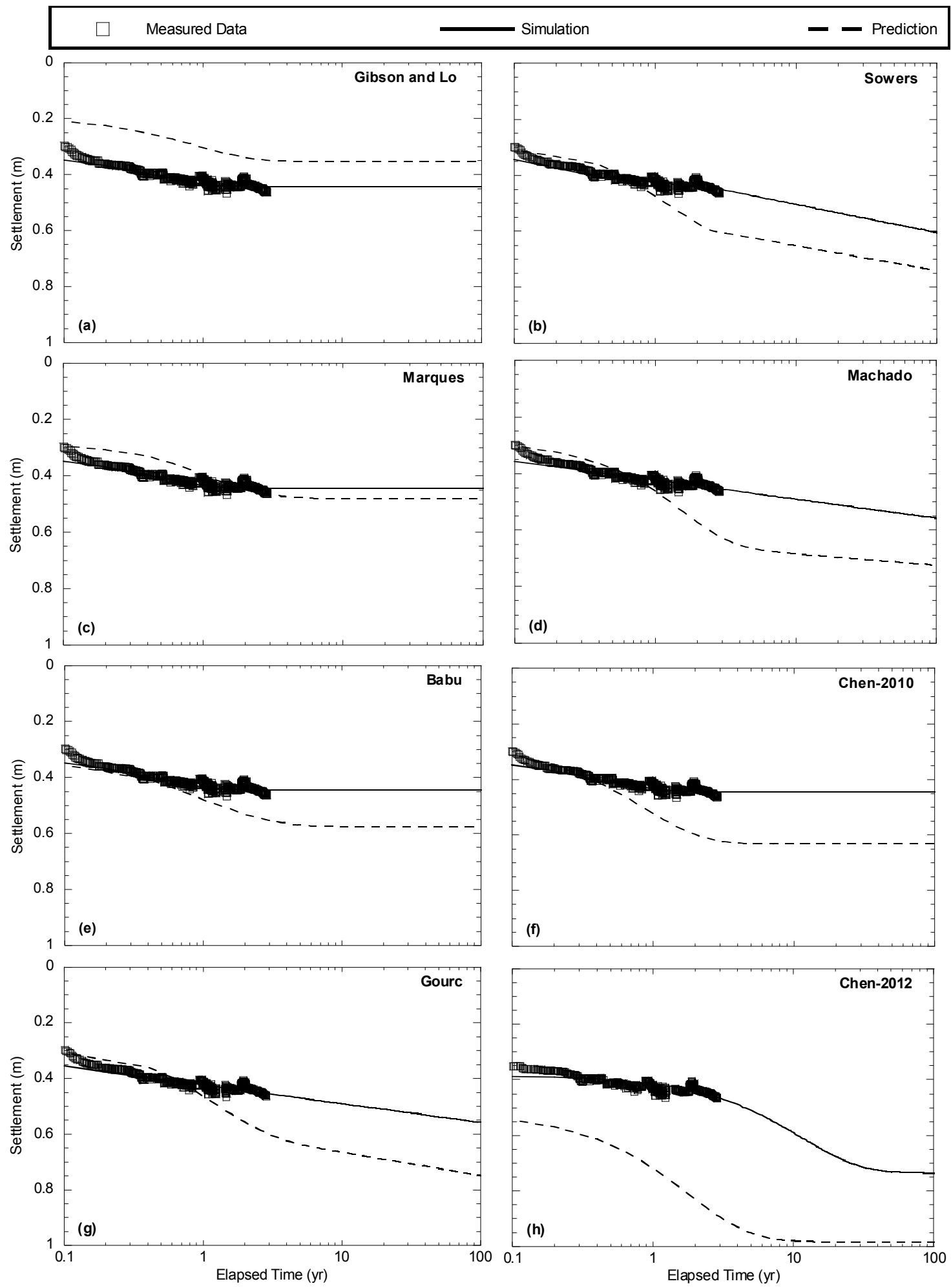

Fig. 14. Measured, simulated, and predicted settlement for Waste Layer 4 in the DTBE. Predicted settlement is based on the arithmetic average of optimized model parameters from the four simulated waste layers. 